Portland State University

PDXScholar

1981

\title{
Mission of protest : General John Armstrong's response to the continental system, 1806-1810
}

Thom M. Armstrong

Portland State University

Follow this and additional works at: https://pdxscholar.library.pdx.edu/open_access_etds

Part of the European History Commons, Political History Commons, and the United States History Commons

Let us know how access to this document benefits you.

\section{Recommended Citation}

Armstrong, Thom M., "Mission of protest : General John Armstrong's response to the continental system, 1806-1810" (1981). Dissertations and Theses. Paper 3195.

https://doi.org/10.15760/etd.3186

This Thesis is brought to you for free and open access. It has been accepted for inclusion in Dissertations and Theses by an authorized administrator of PDXScholar. Please contact us if we can make this document more accessible: pdxscholar@pdx.edu. 
AN ABSTRACT OF THE THESIS OF Thom M. Armstrong for the Master of Arts in History presented July 17, 1981.

Title: Mission of Protest: General John Armstrong's Response to the Continental system, 1806-1810.

APPROVED BY MEMBERS OF THE THESIS COMMITTEE:

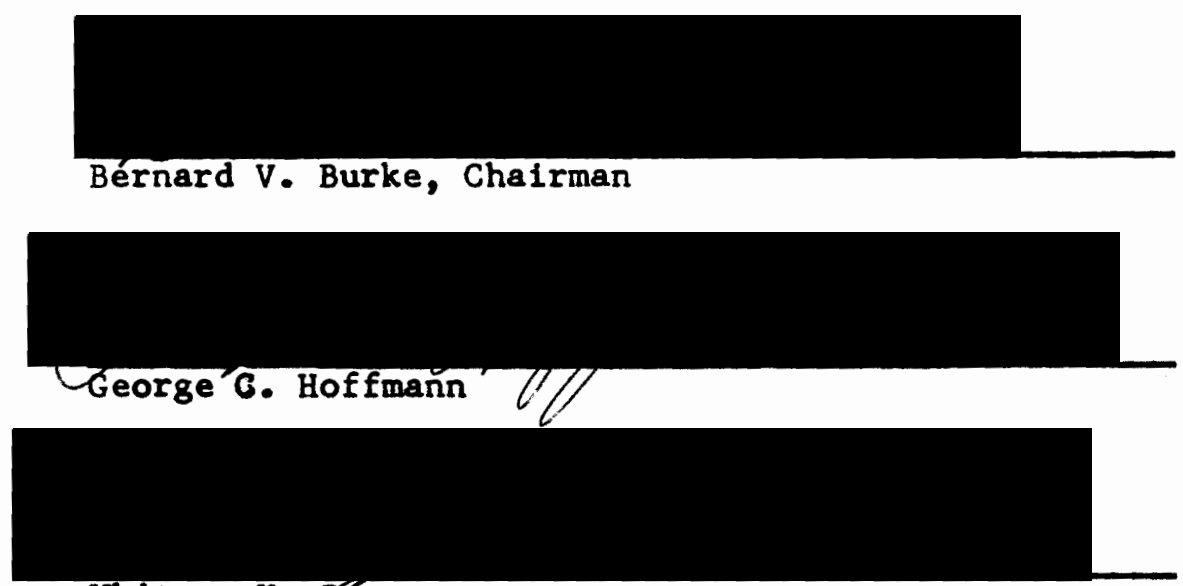

Whitney K. Dates

Although not well known to students of American history today, General John Armstrong was, in his day, a prominent and colorful public figure. From 1804 to 1810 , he held the difficult position of United States Minister to France at a time when the world was in upheaval resulting from the Napoleonic Wars. As Great Britain and France struggled for supremacy, the United States--the world's foremost neutral commercial power--was slowly, but inevitably, drawn into this struggle, becoming the victim of the hostile edicts of the two major belligerents, as they wantonly violated established practices of international law. 
As the diplomatic representative of the American government in France, General Armstrong was reponsible for defending the rights and pursuing the interests of his country. The difficulty of his task was compounded by the United States' military and naval weakness. General Armstrong's position was further undermined by the philosophical beliefs of American leadership, who shied away from possible confrontation, and who would have done so even if they had possessed adequate military and naval strength. American leadership-as epitomized by Thomas Jefferson and James Madison--substituted peaceable economic coercive practices for military force as a means to exert pressure on the belligerents in order to secure concessions from them. In a world governed by force, these principles were unrealistic.

From 1806 to 1810 , the period emphasized in this theeis, Armstrong's greatest concern by far was defending American neutral rights being violated by Napoleon's Continental system, formally Inaugurated by the Berlin Decree of November 21, 1806. Armstrong's mission became one of protest and frustration as Napoleon's decrees were brutally applied to American commerce.

The picture that emerges of Armstrong from this study is one of a determined, forceful, unintimidated, and outspoken defender of American interests. Fully cognizant of Napoleon's character, he was under no illusion as to his prospects for diplomatic success. Armstrong was a realist who, having exhausted normal diplomatic means, urged American leadership to employ force in order to acquire desired territorial objectives, to force Napoleon to respect American 
rights, or to at least make a show of arms for the sake of National honor. This advice, however, was consistently refected by Jefferson and Madison.

In the final analysis, Armstrong's mission was a failure, in the sense that he was unable to force Napoleon to respect American neutral rights by repealing his offensive decrees. Nor was he able to convince American leadership to accept his suggestions on several occasions when standard diplomatic practices were unproductive, to use more forceful measures. However, given the circumstances of the times and Napoleon's character, Armstrong's performance was remarkable indeed, and he did as well as anyone could have. The United States of the early 19th century would have had great difficulty finding another person who could have done better. There were certainly many who would not have done as well.

The unpublished recorde of the Department of State in the National Archives, and the American State Papers are the most important sources for this thesis. They have been augmented with published and unpublished papers of such key f1gures as Thomas Jefferson and James Madison. 


\begin{abstract}
MISSION OF PROTEST:
GENERAL JOHN ARMSTRONG'S RESPONSE

TO THE CONTINENTAL SYSTEM, 1806-1810
\end{abstract}

by

THOM M. ARMSTRONG

A thesis submitted in partial fulfillment of the requirements for the degree of

MASTER OF ARTS

in

HISTORY

Portland State University

1981 
TO THE OFFICE OF GRADUATE STUDIES AND RESEARCH:

The nembers of the Committee approve the thesis of Thom M. Armstrong presented July 17, 1981.

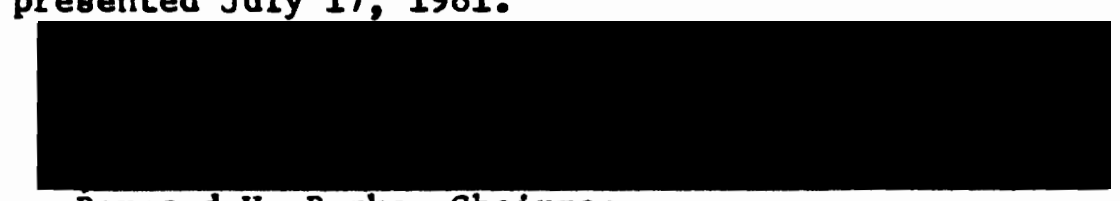

Bernard V. Burke, Chairman
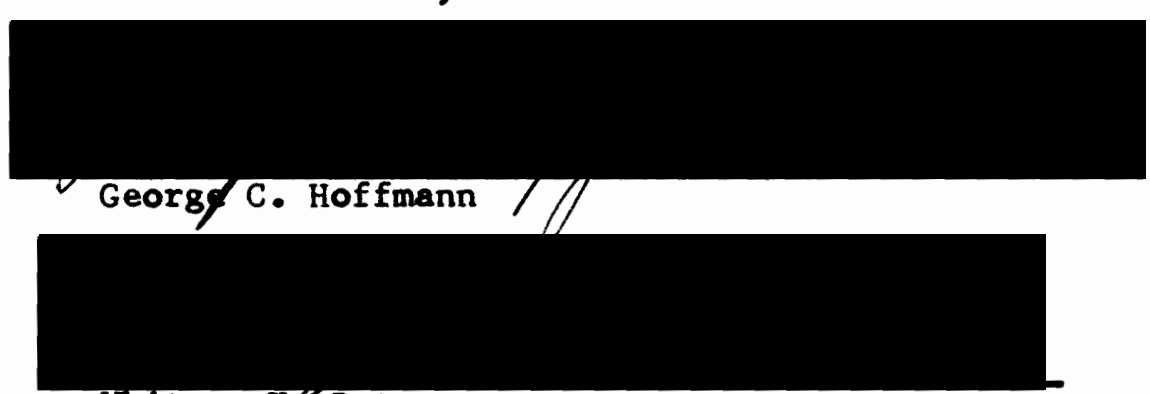

Whitney $\mathrm{K} \mathscr{C}$ Bates

APPROVED:

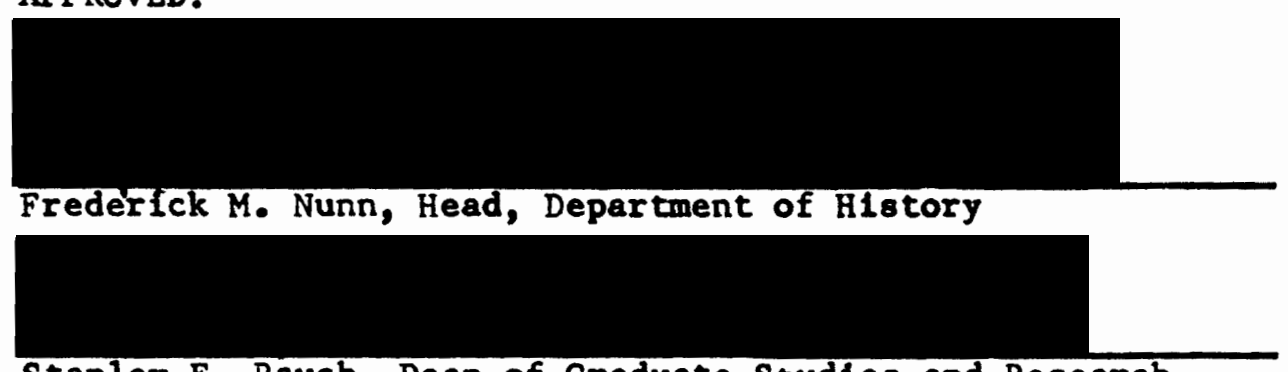

Stanley E. Rauch, Dean of Graduate Studies and Research 


\section{PREFACE}

Although not well known to students of American history today, General John Armstrong was, in his day, a prominent and colorful public figure. From 1804 to 1810 , he had the dublous honor and difficult task of serving as United States Minister to France, at a time when the world was in upheaval reaulting from the Napoleonic Wars. As Great Britain and France struggled for supremacy, the United States--the foremost neutral commercial power-was slowly, but Inevitably, drawn into this struggle, becoming the victim of the hostile edicts of the two major belligerents, as they wantonly violated established practices of international law.

As the diplomatic representative of the American govermment in France, General Armstrong was responsible for defending the rights and pursuing the interests of his government. The difficulty of his task was compounded by the United States' military and naval weakness. General Armstrong's position was further undermined by the philosoph1cal beliefs of American leadership, who shied away from confrontation, and would have done so even had they possessed adequate military or naval strength. American leadership--as epitomized by Thomas Jefferson and James Madison--substituted peaceable economic coercion practices for milltary force as the means with which to exert pressure on the belligerents. In a world that was being governed by force, these principles were unrealistic. The inability of the United States to take a firm posture in 1 ts defense only encouraged the two great belligerents 
to persiat in policies which were 80 detrimental to the welfare of the United States. The military posture of the United States and the inclinations of 1 ts leaders, coupled with the amoral character of Napoleon, made any miseion to France by an American minister almost hopeless from the very beginning.

With the exception of Henry Adams' monumental work, A History of the United States During the Administrations of Thomas Jefferson and James Madison, 9 volo. (New York, 1889-91), Armstrong's career as a minister to France has most often been examined only superficlally. By far the most important aspect of Armstrong's career, on which historlans have concentrated, is h1s tenure as Secretary of War from 1813 to 1814. Even in Adams, in which Armstrong is at least a central figure throughout a great portion of the narrative, Armstrong's diplomacy represents only one part of his work devoted to the comprehensive examination of two important presidencies.

Believing Armstrong's diplomatic career to be deserving of greater attention, this study will examine and assess General Armstrong's performance as United States Minister to France. Though his mission Involved many 18sues, the most important aspect of his mission was to defend American neutral rights that were violated by Napoleon's Continental System, and this otudy will be most concerned with this 188ue, concentrating on the years from 1806, when Napoleon formally Inaugurated his Continental System with the Berlin Decree of November 21, 1806, until the end of General Armstrong's mission and his departure from France in October, 1810. 


\section{ACKNOWLEDGMENTS}

I am deeply indebted to Bernard V. Burke, Professor of History at Portland State University, for having sparked my interest in diplomatic history, for having served as a model of what an excellent teacher should be, and for his advice and efforts as chairman of my thesis comittee.

Equally important to my study of history has been George C. Hoffmann, Professor of History and Dean of the College of Soclal Sclence at Portland State University. His generous advice and encouragement for many years have been greatly appreclated, and have in no small way influenced my determination to pursue advanced studies.

Finally, I can not express my thanks enough to my wife, Cheryl. Her skills as a typist and editor have been invaluable, as has her support. 
TABLE OF CONTENTS

PAGE

PRERACE . . . . . . . . . . . . . . . . . • 111 ACKNOWLEDGMENTS ...................... CHAPTER

I PRELIMINARIES ...................... 1

Appointment and Arrival in France ........ 3

II BACKGROUND OF THE CONTINENTAL SYSTEM . . . . . . . 12

Antecedents for the British Order in Counc11 of May 16,1806 ......... 14

III INAUGURATION OF THE CONTINENTAL SYSTEM:

BERIIN DECREE

The Case of the Horizon ........ 30

Advocate of Action ........... 33

IV CONTINENTAL SYSTEM ENFORCED ............. 41

Milan Decree ............... 42

Choice of Enemies ........... 49

Embargo Act ............... 51

v CONTINENTAL SYSTEM INTENSIFIED ............ 62

Bayonne Decree ............... 63

Retreat to Bourbon d' Archambault ....... 69

The Count Romanzoff Initiative ........ 76

VI MOUNTING FRUSTRATIONS ............. 85

Embargo Repealed, Non-Intercourse,

A New Administration ............ 90 
vii

News from England .............. 97

Interviews with Hauterive .......... 102

Secret vienna Decree ........... 210

VII DIPLOMATIC GAMBLES ............... 118

Journey to Holland ............. 118

The Altenburg Letter ............ 122

The President' Proclamation ......... 123

vIII CABINET REBELLION ................ 130

The "Morose" Minlster ............ 134

IX NAPOLEON REJECTS CABINET ADVICE: ABUSES CONTINUE • • 141

Rambouillet Decree ............ 149

The Non-Intercourse Act Repealed, and Macon's Bill No. 2 Passed ........ 151

X DECREES "REPEALED" ............... 159

The Cadore Letter and Trianon Tariff

of August 5, $1810 \ldots \ldots 163$

Reaction in America ............... 169

Armstrong Criticized ........... 175

XI END OF MISSION .................. 190

XII CONCLUSION ................... 195

SOURCES CONSULTED ................... 204 
CHAPTER I

\section{PRELIMINARIES}

John Armstrong was born in Carlisle, Pennsylvania, on November 25. 1758, the son of the elder John Armstrons, a major-general in the Continental Army during the American Revolutionary War. The younger Arnstrong also particlpated in the war, serving on the staffs of Generals Mercer and Gates, repectively. He was involved in the Saratoga campaign, and was present at the surrender of British General John Burgoyne. At the conclusion of hostilities with Great Britain, Armstrong had attained the rank of major, and was alde-de-camp to General Gates. While serving in this position, Armstrong authored what became known as the "Newburgh Letters" in March, 1783, while the Continental Army was encamped along the Hudson River. ${ }^{l}$ Although written with good intentions, this act earned Armstrong a reputation as an Intriguer, which he was never able to completely shake, although the authorship of the letters was not immediately known. 2 The letters "exhibited a facility in caustic reasoning, mixed with skillfull emotional appeal," for which Armstrong was noted. 3

After the conclusion of the Revolutionary War, Armstrong held several important positions in Pennsylvania--Secretary of the Supreme Executive Council, Adjutant-General, and elected delegate to Congress in 1787. His marriage in 1789 to Alida Livingston, ister of Chancellor Robert R. Livingston of New York, placed him in one of America's most 
prestigious and aristocratic familles, and guaranteed his future as an important polftical figure in New York State and national polftics. He moved to Red Hook, Dutchess County, New York, where he devoted his energies to the pursuit of agriculture for eleven years, and prepared himself for the active and demanding public career that was to follow. Although the Livingston clan had nominally been Federalists, their opposition to the Allen and Sedition Acts of the Adams Administration caused the family, including Armstrons, to join the Republicans. ${ }^{4}$ Armstrong's literary talents greatis contributed to the standing of the party with the successful publication of a "vitriolic" petition calling for repeal of the acts. 5

The political alliance of the Livingston and Clinton familles helped to carry the state for the Republicans in the election of 1800 . This victory made George Clinton Governor of New York, and the two familles succeeded in destroying the patronage privileges of Cifnton's rival, Aaron Burr, the newly-elected Vice-President of the United states. Consequently, the Livingetons and Clintons reaped the political apolls that came their way. The Chancellor was appointed by President Jefferson as minister to France, and Armstrong, in November, 1800, was chosen by the New York State Legislature to represent that atate in the United States Senate. 6 In February, 1802, Armstrong, resigned his Senate seat to make way for Dewitt Clinton. ${ }^{7}$ In November, 1803, when Dewitt Clinton resigned to become Mayor of New York, Governor George Clinton appointed General Armstrong to fill the vacancy in the Senate. 8 He served in this capacity until June 30, 1804, when Armstrong again resigned, this time to accept President Jefferson's offer to become 
Chancellor Livingston's successor minister to France. 9

APPOINTMENT AND ARRIVAL IN FRANCE

In a letter of May 26, 1804, General Armstrong was Informed by President Jefferson that he was the choice of the Administration to succeed Robert Livingston as the American minister to France. 10 If Armstrong accepted, he was to proceed to Washington as soon as possible to fariliarize himself with the diplomatic correspondence from Paris, London, and Madrid, as the Chancellor was arxious to be relleved of his duties in France. 11

In accepting the appointment to become the next minister to France, Armstrong was certainly not motivated by the prospects of pecuniary rewards. A deficient salary was not, in itself reason for Armstrong to reject the appointment. He had long ago learned to live within his means and was not an extravagant man. If he hesitated at all in accepting this cell, it was due only to his desire to possess the necessary ability to perform the duties required in such an important position. 12

Jefferson's motives In appointing Armstrong are questionable. The most logical reason appears to be his desire to maintain political harmony with the Livingston-Clinton faction of the party in New York. Another plausible motivation was his friendship with Chancellor Living8ton. Some historians have suggested that Jefferson may also have seen an opportunity to remove a far too independent senator from the Senate. $^{13}$ Armatrong's independence is unquestionable. In his instructions from Secretary of state James Madison, Arm- 
atrong was Informed of possible changes in the form of the French government, afnce Iivingston's despatches had intimated the creation of, or the intention to create, an empire with Napoleon as emperor. If this was indeed the case, Armstrong was to transmit this immediately to the United States if the new government refused to receive him because of his inappropriate credentials. 14 Further indications of changes in the government were related to Armstrong just prior to his departure for France, although no official notification of this event had as yet been recelved. Recognizing a potentially embarrassing position for the United states, and not wanting to offend the sensitivities of Napoleon, Madison informed Armstrong that, in order to reduce possible delays in his reception at Paris, he would be furnished with a blank commission and letters of credence, to be filled in when he reached Paris and the disposition of the French goverment was fully known. 15

On about September 7, 1804, General Armstrong and his family set $8 a 11$ from New York. They arrived in Nantes, France on about October 14, 1804. 16 From Nantes, the Armstrongs travelled to Par1s, arriving there October 30.17

Armstrong immediately had an interview with Charles Maurice de Talleyrand-Pèrigord, the French Minister of Foreign Relations. 18 Livingston requested from Talleyrand that Armstrong be allowed to conduct business at least informally before his presentation to the Bmperor, but this was deemed impossible. In describing the changes that were taking place as the Republic was being transformed into the Empire, Livingston made an observant comparison with former times:

Here everything that resemble the old Court is eagerly 
sought after \& imitated, \& we are so hedged in with oone forms that are not yet velfgunderstood, that we are all somewhat at a loss how to act-...

In a few daya, however, General Armstrong and Chancellor Livingston were admitted to a private audience with Napoleon, the man who would make Armstrong's ax years in France extremely frustrating and difficult. Livingston presented his letter of recall, and apologized for 1ts having been addressed to the First Consul. He referred to Armotrong for assurances that the President had recognized that a change in the form of the French government had indeed occurred. 20 Armstrong presented his credentials to the Emperor, then delivered a few complimentary remarks regarding the Emperor's recent elevation. ${ }^{21}$ Having completed his last official diplomatic functions, Livingston departed Paris for Italy, where he planned to pass the winter before returning to the United states. ${ }^{22}$ No doubt, Livingston was anxious to extricate himself from the claims controversy, and was all too willing to let his brother-in-law deal with it. This controversy, and negotiations for West Florida were more than enough to keep the new minister occupied during the early stages of his diplomatic career. ${ }^{23}$ This experience in dealing with Napoleon and other French officials during this early period, would prove to be invaluable when he was called upon later to defend American neutral rights against the Continental System. To this lsoue we will now turn. 
Notes

Chapter I

While the army was camped at Newburgh on the Hudson River, discontent over the fallure of Congress to meet arrears of pay was widespread. At the instigation of Horatio Gates, Armstrong composed the "Newburgh Letters" which called a meeting of the field officers and representatives of the officers of each company to consider relief measures. They sugsested that, as petitions to Congress had not been heeded, the army should take matters into its own hands if Congress falled to fulfill its obligations. For an examination of the "Newburgh Letters" controversy, see Richard H. Kohn, "The Inside History of the Newburgh Conspiracy: America and the Coup d'Etat," Willian and Mary Quarterly, 3rd ser., XXVII(1970), 187-213; Paul David Nelsonwith a rebuttal by Rlchard H. Kohn, "Horat1o Gates at Newburgh, 1783: A Misunderstood Rule," W1111am and Mary Quarterly, 3rd ser., XXIX (1972), 143-158; C. Edward Skeen with a rebuttal by RIchard H. Kohn, "The Newburgh Conspiracy Reconsidered," W1111am and Mary Quarterly, 3rd ser., $\operatorname{XxxI}(1974), 272-298$

${ }^{2}$ George Washington withdrew the harsh opinion he had held of the letters and their author in a letter to Armstrong of February, 1793. He stated that he had "olnce had sufficlent reason for belleving, that the object of the author was just, honorable, and friendly to the country, though the means augested by him was certainly liable to much misunderatanding and abuse." John C. Fitzpatrick, ed., The 
Writings of George Wahington, 39 role. (1940; rpt. Westport, Conn., 1976), XXXV, 397.

${ }^{3}$ Allen Johnson and Dumas Malone, eds., Dictionary of American Biography, 22 vols. (New.York, 1946), I, 355; hereafter c1ted as Dict. of Am. B10.

${ }^{4}$ See DeAlva stamwood Alexander, A Polltical History of the state of New York, 3 vols. (New York, 1906), for an account of New York political history. Descibes the intense partisan nature of New York politice at this time. Author is occasionally critical of Armotrong, though.

5 Alexander, I, 89.

${ }^{6}$ other members of the Livingston family were also appointed to important offices: Edward, a brother, was made Mayor of New York; Thomas Tillotson, a brother-in-law, Secretary of State; Morgan Lewis, another brother-in-law, Chlef Justice; and Brockholst Livingston, a cousin, justice of the Supreme Court. Dict. of Am. Bio., I, 356. Annals of Congress: Debates and Proceedings in the Congress of the United States, 42 vols. (Washington, D.C., 1834-1856), 8th Cong., lot ser., P. 185; hereafter c1ted as Annals.

8 Dict. of Am. B10.. I, 356. Armstrong was known as "General" prior to and during his years as U.S. minister to France, although he did not actually hold a commission as a Brigadier-General until June, 1812, when he was appointed by Madison to take charge of the defense of New York City. According to Beckles W11lson, Amerlca's Ambassadors to France, 1777-1927: A Narrative of Franco-American Relations (London, 1928), 93, as Armstrong rose in political favor, 0 too did his rank, a common practice of the time. He was almost always referred to as 
"General."

${ }^{9}$ Dict. of Am. B10., I, 356.

10 Jefferson to Armetrong, May 26, 1804, Paul Leicester Ford, ed., The Writings of Thomas Jefferson, 10 vols. (New York, 1892-99), VIII, 302-303; hereafter c1ted as Writings of Jefferson.

11 The convention of 1803 which concluded the sale of Loulsiana also established a fund of $\$ 3,750,000$ to liquidate legitimate American claims against France. Although livingston thought that this amount was more than adequate, it was far too 11ttle. The shortage of funds, plus the complicated procedures for dispersing claims money, soon embroiled Livingston in quarrels with the American Board of Comiseioners. Livingston was charged with favoritism by his own associates, and the situation was not improved when he in turn attacked the Board with similar charges. These events, plus Livingston's own political ambitions, made him anxious to return to the United States. When Armstrong arrived in Paris to take up his post, he was immediately thrust into a controversy not of his making, but exascerbated due to his family connection with Livingston. For an account of the claims controverey, see Irving Brant, James Madison, 6 vols. (1948-61, Indienapolis), IV, 213-229.

12 Armstrong to Jefferson, June 2, 1804, Thomas Jefferson Papers, Manuscript Division, Library of Congrese, Washington, D.C., microfilm copy, Reel 30; hereafter cited as Jefferson Papers LC, followed by reel. Jefferson was concerned that Armstrong mlght not accept the position because of rumors that had circulated regarding the inadequacy of salaries for American diplomats. See Jefferson to Armstrong, 
May 26, 1804, Writinge of Jeffereon, VIII, 302-303. William Pinkney, American minieter to London, was one who was upset about the amount of his salary and wrote that it was "dreadfully inadequate" and belleved that General Armstrong was probably no better off in Paris. Pinkney to. Madicon, Aug. 19, 1809, In Henry Wheaton, ed., Some Account of the Life, Writings and Speeches of William Pinkney (New York, 1926), 96-97. In another letter to Madison of August 13, 1810, Pinkney requested permission from President Madisan to end his mission as the amount allotted to repreeentetives abroad was a "pittance," and he was a "constant and progressive loser, and at length... incapable of supplying the deficienclee of the public allowance." Pinkney to Madison, Aug. 13, 1810, 1bid., 105-107. Armetrong's salary was $\$ 9000$ per year with one-fourth salary earmarked for his return trip.

13 Dict. of Am. Bio., I, 356. See al so Henry Adams, A History of the United States of America During the Administrations of Themse Jefferson and James Madison, 9 vols. (New York, 1889-91), II, 157; hereafter c1ted as Adame. 14 Madison to Armatrong, July 15, 1804, U.S. Department of State Records, National Archives, Washington, D.C., Instructions, All Countries, Vol. VI, P. 247, microfilm copy; hereafter cited as NA Instructs., followed by volume and page.

15 Madison to Armstron8, Aug. 21, 1804, NA Instructs., vI, 253-254.
16 Armstrons to Madison, Oct. 14, 1804, U.S. Department of State Records, National Archives, Washington, D.C., Despatches From United States Minieters to France, Vol. IX, microfilm copy; hereafter cited as NA Despatches, followed by volume. 17 Armstrong to Madison, Nov. 21, 1804, NA Despatches, 
18 Ibid.; Alexander DeConde, The Quasi-War: The Politics and Diplomacy of the Undeclared War With France, 1797-1801 (New York, 1966), 41, refers to Talleyrand as "an unscrupulous, pleasure-loving aristocrat of elegant taste and loose morals who had once been a bishop in the Catholic Church and whose talent as a diplomat was known throughout the world....."

${ }^{19}$ Livingston to Madison, Nov. 17, 1804, NA Despatches, Vol. IX. ${ }^{20}$ Livingston to Madison, Nov. 21, 1804, NA Despatches, Vol. IX. 21 Armstrong to Madison, Dec. 24, 1804, NA Despatches, Vol. X. 22 Iivingston to Madison, Sept. 14, 1804, NA Despatches, Vol. IX; Livingston to Madison, Nov. 21, 1804, NA Despatches, Vol. IX.

${ }^{23}$ Following the purchase of Louisiana in 1803, the acquisition of the Floridas--especially West Florida--became Jefferson's overriding desire. In the negotiations which followed, Ammstrong sought to solicit French support in this endeavor. He quickly learned that Napoleon was a man of expediency whose promises were frivolous. At one point, the Emperor would seem to side with the Americans, then he would quickly reverse himself and side with the Spaniards when it appeared to be to his advantage. As early as 1805, Armstrong, recognizing the precarious position in which the United States found itself, advised the use of force as a means to acquire territorial objectives-a course that he rould continue to advocate throughout his career in France whenever standard diplomatic means had failed. Armstrong to Monroe, May 4, 1805, NA Despatches, Vol. $X$. When the Chesapeake incident of June, 1807 occurred, the negotiations for West Florlda ended, for all practical purposes. However, Napoleon still did not hesitate to dangle the 
11

prospect of acquiring the Florida before Jefferson and Madison on various occasions when it worked to his advantage. Although Armstrong's mission after 1807 became more concerned with the defense of American commercial rights, he also continued to promote American interest in the Florldas. For a detailed account of the West Florida negotiations, see Isaac Joslin Cox, The West Florida Controversy, 1798-1813: A Study in American Diplomacy (Baltimore, 1918). 
BACKGROUND OF THE CONTINENTAL SYSTEM

The British naval victory at the Battle of Trafalgar on October 21, 1805, for the most part guaranteed British control of the seas, and the ability to cut off French trade with France's colonies or her al. 1ies' colonies, or with neutrale. For the time being, the threat of an invasion of Great Britain by France had been eliminated. ${ }^{1}$ Unable to defeat Great Britain at sea, Napoleon therefore tried to strike where he thought that it would hurt most--her ability to trade. After Trafalgar, Napoleon decided that he would become the master of the land if Great Britain were to be the mistress of the seas. In his scheme, not only would European ports be closed to British commerce, but also the ports of colonies of European countries. With no place to trade, the financial basis of British naval and military power would collapse. The ensuing commercial warfare of the two belligerents necessitated the United States being drawn into the middle of this great struggle. Both Great Britain and France resorted to retaliation, or the pretext of retallation in their atruggles. Exactly who was respon-ible for the "original ofn" which may have justified the Initial retaliation, 1s still a point which has yet to be determined. Each adversary, however, was more than happy for the pretext to use the weapon of blockade. ${ }^{2}$ Parallel to the French commerclal blockade, a oystematic persecution of trade with enemy countrles was taking place, 
primarily on the British ide. Both of these developments were united to form the characteristics of the Continental system. ${ }^{3}$

In the system of maritime blockade, blockading an enemy's porte and cossts unquestionably formed the primary basis of the continental System. Characteristic of the system, however, was the practice adopted by Great Britain of establishing a so-called "paper blockade," a declaring in a tate of blockade, long stretches of coast which she could not, or would not, enforce effectively by providing the necessary naval forces. On the strength of this declaration, she would capture neutral vessels bound for almost any enemy port. ${ }^{4}$

The Continental System originated, therefore, on one side, in a blockade that followed the general lines of mercantile trade policy, and on the other side, in a maritime blockade dominated by the same ideas. Owing to the British mastery of the seas, however, the practical effect of this plan in France was to produce a self-blockade. To complete the antecedent conditions of the Continental system, there was only one feature lacking. It was the feature that has given the system its name--that is, combining European countries to the exclusion of Great Britain, creating a coumon self-blockade of the Continent against Great Britain. 5

In a strictly technical sense, the responsibility for prompting the chain of retaliation rests upon Great Britain. It was ostensibiy her Order in Council of May 16, 1806, that triggered the series of French decrees and British Orders in Council which so harshly violated American neutral rights. 6 To understand the significance of the British action of May, 1806, a brief outline recounting practices and events 
prior to the passage of these orders may be useful.

ANTECEDENTS FOR THE BRITISH ORDER IN COUNCIL OF MAY 16, 1806

After the truce of Amiens between Great Britain and France ended In May, 1803, Americans continued to enjoy a profitable commerce from the war, just as they had during the earlier years of the Anglo-French conflict. This rich trade led to the tremendous growth and development of the American merchant marine, making the United States the world's most Important neutral carrier. Americans were able to enjoy a trade denied them during the years of peace, in carrying goods between French ports and Spanish colonies. Since this trade was a violation of the British Rule of $1756,{ }^{7}$ Americans took their cargoes from French or Spanish ports to an American port where they went through certain formallties, such as the payment of dutles, which might later be refunded. The cargoes were thus considered American property, making them "free goods." The sh1ps with their "neutrallzed" cargoes might then proceed to France or Spain. England herself recognized the legality of this trade in 1800, In a decision handed down by the High Court of Admiralty in the case of the American ship, Polly. This type of trade, which circumvented the Rule of 1756, was known as "broken voyage." In 1805, however, this trade came to an end. With increasing protest in England, the Lords Comaissioners of Appeals in London reversed the Polly decision In the case of the American brig, Essex.

Goode could no longer be neutralized by bringing them into a neutral country. The shipper had to pay a bonafide import duty. To refund the duty upon re-exporting the goods was considered subterfuge 
and constituted a "continuous voyage" from enemy homelands to an enemy colony. According to the British, "broken voyage" violated the Rule of 1756, and under the "continuous voyage" doctrine, they would no longer permit ouch trade. Without any advance warning, and before the Essex decision had even been publicized, British cruisers seized scores of American shipe carrying French or Spanish goods, especially those found in the Caribbean. Consequently, American ports were practically blockaded.

With the defeat of the Spanleh and French fleets at Trafalgar, England's maritime supremacy was established, making it possible to enforce even tighter control over neutral shipping. On the same day, October 21, 1805, a pamphlet by Admiralty lavyer, James Stephen, ent1tled "War in Disguise; Or, the Frauds of the Neutral Flags", appeared in London. Stephen argued that neutral shipping should be regulated and taxed for Britain's war effort. Allowing neutrals, especially the Americans, to trade unhampered with the enemy, helped to sustain French ambitions, and prolonged Europe's miseries. Scott further argued that England denled herself the advantages of her command of the seas. Since she, in effect, controlled the seas, neutrals had no rights. These were popular ideas with the British people and subsequent Orders in Council basically followed this argument.

Within one month, however, Napoleon won the Battle of Austerittz, and crushed the armies of Russia and Austria, destroying the third coalition against France and etrengthening his mastery in Europe. Neither power, Great Britain nor France, could get at each other directly, but in the squabble which followed, neutral rights, for all practical 
purposes, disappeared, and the United States suffered greatly.

In Its approach to the United States, Great Britain adopted a policy designed to protect British shipping and commerce, seen as the source of British greatness. These could be further encouraged by the use of traditional remedies of trade restriction, regulation, and the stifing of competition. The fact that Americans appeared as weak, uncouth, boasting, as well as dependent upon Great Britain, greatly encouraged the British to pursue their policies. British policy toward the United States combined about equal parts of monopolistic mercantilism, and a desire to atrangle Napoleon. 8

With the death of Prime Minister William P1tt on January 23, 1806, Charles James Fox was named Forelgn Secretary in the Ministry of "All The Talents." Fox was pressured to devise a measure that rould not only eatisfy pressures within Great Britain, but because of his sympathy for the Americane, would also serve to mollify them. The result was the Order In Counc1l of May 16, 1806. In substance, th1s order declared a blockade of the European coast from Brest to the Elbe, dividing that stretch into two zones. Between the Seine RIver and the port of Ostend, the order would be strictly enforced. In the remaining area, neutral shlps would be allowed to trade in non-contraband goods, provided they did not come from a hostile port. Th1s meant that ships which broke their voyage by neutralization at an American port, as was comon before the Essex decision, might be allowed to bring cargoes into enemy porto like Rotterdam and Bremen in the outer zones, and to all nonblockeded enemy porte, such as those south of Brest. ${ }^{9}$

Although an underetanding that the order would not be enforced 
on this section of the coast was intended to mollify the Americans, the order, nonetheless, did not receive a favorable response in the United States. It was attacked as an 111 egal paper blockade, and the United States refused to repeal its Non-Importation Act of April 23, 1806, which had been passed as a protest against the Essex decision. 10 Since Great Britain had taken the first step, the next was up to Napoleon, who was only too anxious to formally introduce the system he had been devising to defeat his leading foe. 
Notes

Chapter II

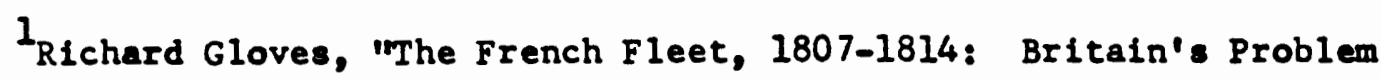
and Madison's Opportunity," Journal of Modern History, XXXIX (1967), 233-252, sheds new 1ight on this commonly held assumption. The author concludes that the defeat of France at Trafalgar did not end any future threat of a French invasion of the British Isles. From 1807-1814, Britain had much to fear as Napoleon consclentiously engaged in a program to build up his navy so as to challenge Britlsh supremacy of the seas.

${ }^{2}$ Samuel Flags Bemis, A Diplomatic History of the United States, 5 th ed. (New York, 1965), 139. For an account of the antecedents of the Continental blockade covering the years 1660 to 1802 , see ElI F. Heckscher, The Continental system: An Bconomic Interpretation (Oxford, 1922), 13-74. This work is one of the most detalled and authoritative on the economic aspects of the Continental System.

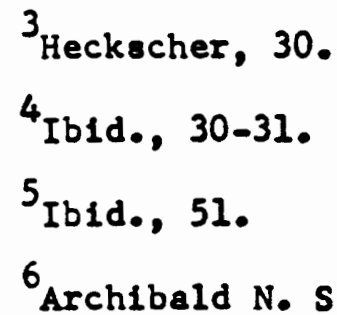
by Napoleon's Decrees, and the British Orders in Counc11, 1806-1813," American Journal of International Law, $X$ (1916), 492-103, examines the legal aspects of these measures as recognized by international lav. 7 The Rule of the War of 1756 declared that trade closed to nationa 
In time of peace could not be opened to them in time of war.

8 Bradford Perkins, Prologue to War: England and the United States, 1805-1812 (Berkeley, 1961), 5-22. By far the best account of Ang10-American relations during this period.

${ }^{9}$ C. J. Fox to Monroe, May 16, 1806, W. Lowrle and M. Clark, eds., American State Papers, Forelgn Relations, 6 vols. (Washington, D.C., 1832-1859), III, 267, microcard copy; hereafter cited as ASPFR, followed by volume and page.

10 Heckscher, 497; Bemis, History, 146. The Non-Importation Act was scheduled to 80 into effect on Nov. I againet British goods unless a eettlement was reached in the meantime between the two countries. Because of Monroe's and Pinkney's mission to conclude a new treaty, the act was postponed and did not go into effect. The treaty signed on Dec. 31, 1806 was inadequate in meeting the requirement of the United States government-mespecially as related to impressment and spoliations. The treaty was rejected by Jefferson. For an examination of American act. of non-importation, wee Herbert Heaton, "Non-Importation, 18061812," Journal of Economic History, I (1941), 178-198. He contends that non-importation has recelved far too little attention in contrast to the Embargo. Heaton concludes that non-importation was mostly ineffective, despite the diligent efforts of such people as Peter A. Schenck, Surveyor of Customs and Inspector of Revenue for the Port of New York, to enforce 1t. 
INAUGURATION OF THE CONTINENTAL SYSTEM: BERLIN DECREE

The years 1803 to 1806 witnessed earth-shattering events, espec1ally in military terms: Napoleon's preparation in 1804-1805 for a descent on England; the foundation of the French Empire (May-December, 1804); the formation of the Third Coalition against France and 1ts defeat at UIm and Austerlitz (October and December, 1805); as an Immediate sequel to this, the Peace of Pressburg, with the extension of the "coast system" to the eastern shore of the Adriatic, but also the defeat of the combined French and Spanish fleets at Trafalgar (October 21, 1805); and finally the formation of the Fourth Coalition and the defeat of Prussia at Jena and Auerstadt (October 14, 1806). 1

In the autumn of 1806, Napoleon's victory on the Continent was as complete as was his defeat at sea. He could point to the Battle of Jena as the natural antecedent to the Continental System, inasmuch as that battle placed him in control of the Weser, Elbe, Trave, Oder, and all the coastline as far as the Vistula. ${ }^{2}$ On October 27, 1806, the victorlous French troops made a trlumphal entry into Berlin, the capital of the country which Napoleon had fust thoroughly defeated. On the pretext of retaliation for Great Britain' 111 egal blockade of May 16 , 1806. the Emperor, on November 21, 1806, 81gned what became famous as h1s Berlin Decree. 3 This oymbolized the formal inauguration of his Continental System. Napoleon surmised that if England were prevented from 
trading with Europe, she would soon be dellvered a fatal blow. The Emperor saw the closing of all ports of the mainland to the British as a neceseary precondition for peace with the Continental powers. Even before the decree's actual promulgation, the Emperor demonstrated that he had, some time beforehand, seen the neceseity of a continental blockade. The Beriln Decree was a culmination of earlier thoughts and measures, but its actual publication st11 had the effect of a bomb, thanks to Napoleon's abllity as a stage manager. 4

The preamble of the decree opened with the charge that England was disregarding the law of nations. She made non-combatants prisoners of war, confiscated private property, blockaded unfortifled harbors and mouths of rivers, and considered places as blockaded though she did not have a single ship before them--even to the extent of blockading whole cossts and empires. According to the decree, the blatant abuse of the right of blockade hed no other purpose than to destroy trade and Industry so as to build up her own on the ruins of trade and Industry on the Continent. France, therefore, had a natural right to use the same wea. pons and methods of warfare against her. Therefore, unt1l England recognized and corrected these violations of law, it was decreed that: (1) the Brit1sh Isles were in a state of blockade; (2) all intercourse with them was prohibited; (3) every Englishman found within French authority was a prisoner of war; (4) all British property, private and public, was prize of war; (5) all merchandise coming from England was prize of war; (6) half the product of euch confiscations should be employed to Indemify merchants whose property had been captured by British cruisers; (7) no ship coming from England or her colonies should 
be admitted Into any port; and (8) every vessel trying to elude this rule by means of false papere would be conflscated. 5

In the meantime, General Armstrong had been observing military and political movements, and assessing their consequences for the United States and its commerce. As early as March, 1806, more than eight months before the publication of the Berlin Decree, Armstrong had suspected that moves were then being made to exclude Great Britain from all intercourse with Northern Europe. 6 Armstrong observed that people in Paris were convinced that a change of ministry in England would not necessarily produce peace. The French professed to know Mr. Fox's true sentiments, thought to be more erroneous than those of Pitt. This belief had aupposedly induced the Emperor to adopt and pursue, "with his characteristical vigor, the system of shutting the ports of Europe against the comerce of England." 7 England was to be Insulated politically and comercially. The rlak to neutrals in "the ardor of this experiment" were clearly recognized by the American minister. "Between the two principles the occlusion of the French and blockading of the Britioh our commerce will be in a pretty eltuation." 8

On December 5, 1806, the text of the Berlin Decree was published In the Moniteur. Almost simultaneously, news arrived that Hamburg, and almost the entire northern coast of Germany along the North Sea and the Baltic, had fallen to Napoleon--or were about to. After Armstrong had observed the success of French arms, and having received knowledge of the Berlin Decree, he might well have felt that he had finally discovered-after numerous attempt8--a concrete 1dea of what the Emperor had been scheming, partially explaining the problems that had plagued 
his diplomacy. It at least gave him a vague 1 dea of what was to come. 9 Armetrong quickly forwarded a copy of the decree to the secretary of state, then directed his efforts toward discerning the actual and intended meanings of the decree--especially as related to American interests. 10 Not one to side-step an 1ssue, Armstrong demonetreted the diligence with which he pursued his duties and forcefully demanded that Decrès, French Minieter of Marine and Colonies, give him "the official explanation which may be given to the Imperial Decree of the 2let of November, 1806, so far as that decree involves the righte of neutral natione."11 More epecifically, Armstrong wished to know whether "British Islands", mentioned in Article I, was to be understood as all islands in the possession of the king of England, or if the rule vould extend the blockade to the continental possessions also. Additionally, Armetrong wished to know if the decree would operate from its date, and if seizures made under it, before notice was given, would be considered legal. Would American vessels, navigating the high or narrow seas, be llable to seizure, on evidence only, that they were going to, or returning from, a British port? Finally, he wanted to know whether Articles II and $v$ would operate only as domestic regulations, or if their injunctions would extend to citizens of forelgn or independent nations. 12

Despite Armstrong's request for a rapid reply to his inquiry, it was not unt1l December 24, 1806, that Decrès finally answered the questions posed, though not as definitively as Armstrong would have preferred. Decrès opened by stating that he considered the decree of November 21, 1806, as conveying no modification of the regulations then 
being observed in France with regard to neutrals, nor of the Convention of 1800 with the United States. ${ }^{13}$ With this, the four questions which Armstrong had asked were, according to Decrès, resolved. In concluding, however, Decrès qualified his remarks by stating that the anewers he had provided could not have as much authority as they would if received from the Minister of Foreign Relations. Armstrong ought to address himself to that minister for explanations, which Decrès had been happy to provide because Armstrong had requested them from him, but upon which Decrès did not possess as much information as the Prince of Benevento did. 14

Decrès' answers were quickly despatched to the Secretary of state In Armstrong's letter of December 24, 1806.15 The President then conveyed them to Congress..$^{16}$ General Turreau, French Minister to the United States also led Americans to believe that the United States had nothing to fear in the Berlin Decree. He had received a despatch from his Court expressly declaring that the decree was not to affect the United States, and that the Emperor was determined to respect American interests and would observe the convention existing between the two countries. 17 The Administration was not only concerned, however, about the Berlin Decree, but $a 180$ about a Spanish decree modelled after the French one, whose terms were even more vague and broad. If it was not recalled or modified, it would undoubtedly produce more spoliations which had already begun in that region, and, of course, "thicken the cloud that hangs over the amity of the two nations." 18 Meanwhile, Armstrong became Increasingly Impatient as the Emperor remained away from Paris so long, winning one victory after another 
which brought him closer to achieving control of the Continent. On February 8, 1807, Napoleon fought the Battle of Eylau. Following this battle, Armetrong became $s 0$ Impatient to test the promise of the Emperor to help resolve America's diepute with Spain, that in May, 1807, he requested passports to proceed to Napoleon's headquarters. This request was denied. 19 If Armstrong had been allowed to 8o, he probably would have witnesed the great Battle of Friedland, fought on June 14, and would have witnessed the Peace of Tilst, eigned on July 7, which eliminated the last obstacle to Napoleon's schemes againat Spain and the United States. 20 After Tilsit, Napoleon and Czar Alexander privately agreed that the remaining neutrals were left to Napoleon to be dealt with as he pleased. 21

Except for Denmark and Portugal, every country on the coast of Europe, from St. Petersburg to Trieste, was forced to recognize Napoleon's domination. England resisted, and for the time being, could not be reached by sea. The next step in the Emperor's gystem, then, was to effect England's ruin by closing the whole world to her trade. The Emperor began with Portugal. From Dresden, on July 19, 1807, he issued orders that the Portuguese ports should be closed by September 1 to English comerce, or the kingdom of Portugal would be occupied by a combined French and Spanioh army.

On July 29, Napoleon returned to Par1s, and, on July 31, he ordered Talleyrand to warn the Prince Royal of Denmark that he must choose between war with England and war with France. ${ }^{22}$ The 1ikelihood that Napoleon would move shortly againet the neutrality atatus of the United states must have been In Armotrong's thoughts when he related 
incidents to the Secretary of state that had occurred at Court. Recognizing that Napoleon had pretty much settled the business of the belligerents to his liking-with the exception of England--he was then at the polnt of settling that of the neutrale in the same way. Armstrong reported that while at Court Napoleon had severely lectured the Portuguese Minister as a result of the conduct of that minister's court. Later, Mr. Dreyer, the Danish minister, took Armstrong aside and inquired of him if any application had been made toward Armstrong about a projected union of commercial states against Great Britain. Not having been approached as yet, no doubt Armstrong must have felt a certain amount of trepidation for the future when Dreyer remarked: ryou are much favored, but it will not last." 23 This was after the Danish minister had been spoken to threateningly by Napoleon. To Armstrong, these incidents seemed to confirm the whispers which had begun to circulate that an army was organizing to the south for the purpose of taking possesetion of Portugal, and another army to the north for a eimilar purpose with regard to Denmark. ${ }^{24}$ Armetrong recognized that he too was expected to benefit from the Emperor's outburets at Court.

As the Danish Minister had predicted, the goodwill of Napoleon toward the Americans did not last very long. Under order from Napoleon, the King of Holland and the King of Denmark were instructed to seize neutral commerce, and to close the Danish and Dutch ports. Imediately the question arose whether United States ships and property were still exempt from the operation of the Berlin decree, in light of the Convention of 1800. The Emperor ruled against them. He stated: 


\begin{abstract}
...navigation offers all corts of difficulties. France cannot regard as neutral flags which enjoy no consideration. That of America, however exposed it may be to the Inaults of the English st11 keep some measure in regard to 1t, and it imposes on them. That of Portugal and that of Denmark exist no longer. 25
\end{abstract}

Shortly thereafter, General Armotrong was informed that the Minlster of Marine and the Council of Prizes were about to receive new orders in reference to the Berlin Decree. Armstrong was informed in a note that there were to be no exceptions in the application of the Berlin Decree, since the decree itself contained none. Armstrong quickly related this information to the secretary of state, recognizing that it might be very important in light of the then-present crisis with England. 26 The Anerican minister was not too optimistic about this latest turn of events. He did not attempt to disgulse the poten: tial seriousness of the situation as it pertained to the United States. He told Madicon that he could not flatter him with:

....the prospect of any change for the better, with respect to 1t. It would appear that the two great rivals of Europe were striving, not only which should do us the most harm, but which should most injure itself, in the measure: persued [sic] in relation to $48_{,} 27$

Armstrong wondered if the most approprlate action for the United States to take would not be to withdraw from comerce for the time being, until the current storm had passed. To him, an embargo, earnestly observed, would, besides securing the present safety and future strength of the country, et an example for friends and enemies alike. It would teach belligerents how important a regular commerce was to their wants, especially one that was honestly neutral. 28 Although Armstrong was quick to reverse his position on the efficacy of an 
embargo when tried by the United States and seen as a failure, Armstrong' auggestion to consider it at this time reflects his concern for the mounting difficulties confronting the United States as a neutral, and illustrates his efforts to find solutions to the predicament.

Armstrong did not have to walt long for greater clarification of the Berlin Decree with regard to the United States. In a letter from Champagny, 29 Talleyrand's successor as Minister of Forelgn Relations, to Armstrong, the Forelgn Minister further confirmed that, contrary to Decrès' earlier profeselons, there were to be no exceptions to the enforcement of the Berlin Decree. The Emperor had determined that every vessel going from English ports with cargoes of English merchandise, or of English origin, was lawfully seizeable by French armed vessels. 30 The fact that orders had been given to enforce the decree literally, was duly transmitted to Madison. Armstrong further acknowledged that the November decree had been devised expressiy for the purpose of embrolling Great Britain with neutral nations. Since the United States remained the only country of that description, then it must be seen as the last means for rendering impracticable an amicable arrangement between Great Britain and the United States. Armstrong had no doubts as to Napoleon's motive in this policy, or its probable effects.

...the moment France pretends to blockade England--England will in turn, pretend to blockade the whole continent of Europe, and thus our trade in every direction, becomes liable to selzure and confiscation. 31

Lacking instructions as to the course he should follow, Armstrong tried to at least minimize the effects of the decree on American com 
merce until relevant instructione were recelved. He offered arguments that he hoped would Impress the Emperor. In responding to Champagny's letter of October 7, 1807, Armstrong grasped the opportunity to ask Champagny if a postponement of the execution of the decree until the issue of the pending negotiation between the United States and Great Britain was known might not indeed correspond with the Emperor's wishes. 32 Armstrong shrewdly called attention to arguments which the Emperor had used as the pretext for lssuing the decree in the first place. When the Emperor recalled his motives, according to Armstrong, he would find among them one of compelling Great Britain to respect the rights of neutral comerce. When, at the same time, he saw that the United States was on the brink of war with Great Britain in defense of those neutral rights, it would then be impossible that the Emperor-with wisdom and a sense of justice--would not refrain from interposing and suspending the execution of a measure "which can have no effect but to lesson, at once, the motives and the means of the United states, In the support of a cause, hitherto belleved to be common to them, and to the French Empire." 33

In Armstrong' observations of a diplomatic audience on October 14, 1807, he reported that Napoleon had rebuked numerous forelgn representatives. Napoleon threatened the ambassador from Portugal that the House of Braganza would reign no more. To the ambassador from Etruria, the Emperor accured the Queen of Etruria of having eecret attachmente to Great Britain. The same accusation was directed to deputies from the Hanse town. Napoleon boasted that he possessed the means of destroying Great Britain. He had 300,000 men devoted to that 
object, as well as 300,000 from Russia who were willing to support his effort to do so. He further vowed that he would permit no nation to recelve a minister from Great Britain unt1l she had renounced her maritime tyranny. Napoleon urged the diplomats to convey this to their respective sovereigns. Under the circumstances, Armstrong realistically calculated that the United States had little room to hope for any substantial relaxation of the blockading decrees, which, as far as they pertained to the United States, had remained unexecuted 80 far. 34 This good luck was about to change.

THE CASE OF THE HORIZON

Although in October, 1807, Armstrong had investigated reports that the Berlin Decree was being applied to American shipping in such places as Bremen and Hamburg, it was in November, in the judgment against the American ship, Horizon, that the first actual "unfriendly" decision of the Counc1l of Prizes under the Berlin Decree occurred. 35 This decision prompted the first of Armstrong's innumerable protests and remonstrances to the French goverment regarding her hostile actions against American maritime rights. His reactions in this particular case are representative of the consistently firm approach which he employed in the defense of American rights-a firmness which demonetrated his lack of intimidation by French officials, including the Emperor himself.

The Horizon had been shipwrecked on May 21, 1807, near Morlalx on the French coast. The Council of Prizes judged that the amount of the sale legally made of the wreck, together with the cargo which was acknowledged not to have proceeded either from English manufactures or 
from English territory, was, according to the 5th article of the Berlin Decree, to be confiscated for the use of the state. ${ }^{36}$ Armstrong's concern over the decision of the Council of Prizes ras clear. He told Champagny that:

The reasons, upon which this decision is founded, are at once 00 new and 80 alarming to the present friendly relations of the two powers, that I cannot but ${ }^{2}$ 1scuss then with a freedom of their wovelty and importance. 37

Armetrong argued that ince the neutrality of the ohip and cargo had been eufficiently established by the Council, the whole ought to be restored, agreeable to the provisions of the Convention of 1800 . Armstrong pointed out that this was an open and unqualified admission that the ship was indeed found within the rules prescribed by the Convention of 1800 , that according to these rules the cargo and the ship ought to have been restored, and that such would have been the fact, but for the operation of the Berlin Decree. ${ }^{38}$

One reason given by the Council of Prizes to justify its decision was that, though one of the principle agents of the Emperor (Decrès) had given a contrary opinion--an opinion which the Council had not been involved with--that opinion was one of an individual and could not offset the Emperor's formal declaration. If this opinion had apparently seemed to permit American trade, it still did not prevent the Counc1l from conforming to the Berlin Decree. ${ }^{39}$

Caustically, Armstrong stated to Champagny that:

It would appear from this paragraph, that, not finding it easy to untle the knot, the council had determined to cut 1 . Pressed by the fact, that an interpretation of the decree had been given by a minister of His Majesty, specially charged with 1 ts execution, they would now escape from thif fact, and from the conclusions to which it evidently leads. 40 
Armstrong informed Champagny that he would submit to Champagny, his letter of December 29, 1806, requesting from Decrès an officlal interpretation of the decree, and his answer of December 24,8 iving Armstrong the 1nterpretation he had demanded. Armstrong further recalled to Champagny that, as late as August 21, 1806, it was understood that Decrès had been the natural organ of the Emperor's will, and it was to him thet Champagny himself had applied for Information relating to the decree. Sensing the strength of his position, Armstrong referred to the allegations of the Council of Prizes, and the reasoning founded upon them, as extraordinary. Armstrong felt justified in requesting that the Emperor set aside the decision of the Council. 41 The firmess with which Armstrong protested the actions of the Council of Prizes in this case certainly was not calculated to endear himself to French officialdom, nor to an Emperor more accustomed to kow-towing representatives of foreign countries--especially representatives from neutrals. Armstrong had established himself quite early as a man not easily intimidated. This note of protest provoked the Emperor to respond, through Champagny. Following the instructions of the Emperor, Champagny, on November 24, 1807, wrote to General Armstrong. Taking the position that it was the intention of the Emperor that every abuse should be repressed, the United States could not cousplain about the measure taken under the Berlin Decree, especially while that country:

...allow that their vessels may be visited by England, that ohe may dras them lnto her ports, and turn them from their destination; while they do not oblige England to respect their flag, and the merchandise which it covers; while they permit their power to apply to them the absurd rules of blockade 
which it has set up with the view of infuring France; they bind themselves by that tolerance towards England to allow also the application of the measures of reprisale which France 1s obliged to employ against her. 42

Champagny further related to Armstrong that the Bmperor regretted that he had to resort to such measures, while recognizing that the commerclal classes may suffer as a result, but it was to England, rather than to France, that proteste resulting from inconveniences to individuals should be addressed. In order to force England to renounce her actions, it had become necessary for the Emperor to confront that country with her own weapons. The unjust pretensions of England would be maintalned as long as those whose rights she violated were silent. Armstrong was informed that the difficulties would be removed if only the government of the United States, after having complained in vain about the Injustice of England, would join with the whole Continent in opposing British violations. 43 Armstrong must certainly have had difficulty in containing himself after reading this flimsy justification for French actions toward the United States.

\section{ADVOCATE OF ACTION}

Having been in France over two years. Armstrong had had ample time to test Napoleon's sincerity and good faith. He knew from pract1cal experience that the Emperor was a man of expediency, and one who would resort to any means to accomplish his objectives, regardless of previous promises or comitments. In order to draw the United states Into Napoleon's system against Great Britain, the Emperor shrewdly dangled the prospect of the Floridas--Jefferson's overwhelming passion 
and the principle object of Armetrong's diplomacy up until this time-before the President. 44 The catch, of course, was that the United States must join in the struggle againet England, and accept Napoleon's aosurances of a maritime peace between the United States and the Continent which would supposedly establish the principle of "free ships, free goods." Armetrong was skeptical about any scheme appearing to involve the United States for France's benefit. Wh regard to the Floridas, Armstrong suggested that is was wiser to act alone, even in the event of war with England. France had done all that could be expected from her, and her promises lately had become quite sparing. ${ }^{45}$ Typical of Armstrong's suggestions throughout his career, he advised firmer action by the United States in acquiring its territorial objectives when diplomacy had falled, and as a means of upholding international respect for the country. Having previously advocated action to acquire the Floridas, Armstrong posed possible action to American leadership, as he had done In 1805 when he had urged the seizure of Texas. ${ }^{46}$ Recognizing the menace confronting the United States from various corners, bequestioned if it might not be wise not only to launch an attack against Canada to the north, but also against the Floridas to the south. The imposition of an embargo, plus the northern expedition would pass for measures taken strictly against Great Britain. The attack on the Floridas would also be seen as a preventive measure againet Great Britain. Knowing that the Secretary of State might see objections to these suggestions that Armstrong did not, Armstrong nonetheless felt that they would greatly Increase the respect for the United States that was lacking. He concluded that: 
.. If executed with prompitude and spirit, they would do more to preserve inviolate your peace and happiness than all the parchment and diplomacy of both hemlspheres put together. One other trial of etrength with an European power puts down all the ridiculoue calculations of their projectione forever.

Not a war monger, General Armstrong did recognize that when diplomacy falled, resorting to arms to acquire American objectives might be the only logical course. But as in h1s previous bid for firmer action-as he would in the many instances to come--the Administration, with falth in peaceable coercion and an abhorrence for war, shied away from confrontation, regardless of the relatively small risk involved, and the prospects for euccess. Armstrong's frustration mounted as he was forced to watch while American rights were violated by an insensitive Emperor, and American leadership continued to refuse stronger action. 48 No one could know for sure what Napoleon's intentions for the United States actually were at this particular juncture, as the Emperor left Par1s on November 14, 1807, to engage in further military campaigns. Armstrong clearly knew, however, that great changes were in store for Italy, Spain, and Portugal. He foresaw that Portugal was to be taken from the Braganzas, and that the Bourbons of Spain were at last to make way for Lucien Bonaparte, who was to marry the Queen Regent of Etruria. ${ }^{49}$ That Armstrong was 80 well informed about projects that were then so carefully concealed, was a credit to his diplomacy. It was not until nearly a month later that Luclen, in his Itallan banishment, received notice of the plan that was intended for him. 50

With evente of such magnitude about to take place (the Battle of Jena, the occupation of Spain and Portugal, among others) Napoleon really had very little time for American concerne regarding the Florida 
negotiations or the enforcement of the Berlin Decree. 51 Armstrong's fears for the royal houses of Spain and Portugal were confirmed. 52 By the time Napoleon reached Milan on December 15, 1807, L1ebon was under the control of Junot, and French garrisons held every etrategical point between Iisbon and Bayonne. The Prince Regent of Portugal, powerless to resiet Napoleon's artay, salled for South America to found a new empire at Rio de Janeiro. Spain was also in Napoleon's hande. When he reached Milan, Napoleon's thoughts were about Spain and her colonies, with which the questions of English and American trade were closely connected. Spencer Perceval'. Orders in Council had appeared In the London Gazette of November 14, and had also followed the Emperor to Italy. 53 A few weeks later, war was declared between England and Russia. No neutral then remained except Sweden, soon to be crushed by Ruseia, and the United States, with which Napoleon would deal severely. 
Notes

\section{Chapter III}

Heckscher, 88 .

2 Ibid.

${ }^{3}$ Frank Edgar Melvin, Napoleon's Navigation Syetem (New York, 1919), 6. A detalled account of the Continental syatem and its internal effects in France.

4Ibid., 88-89. See also Heckscher, 9-10.

${ }^{5}$ ASPFR, II, 806. Stockder, 498-499, tates if all provisions of the decree were to be 11 terally applied, they would have contravened all recognized rules of blockade, even to a greater extent than was the case wth the Order in Counc1l that preceded 1t. He further states that it is hard to decide which side suffered the most abuse. 6 Armstrong to Madison, March 9, 1809, NA Despatches, Vol. X. See also Armstrong to Madison, March 28, 1806, NA Despatches, Vol. X. 7 Armstrong to Madison, March 28, 1806, NA Despatches, Vol. X. 8 Ibid. 9 Adams, 304. ${ }^{10}$ Armatrong to Madison, Dec. 3, 1806, NA Despatches, Vol. X.

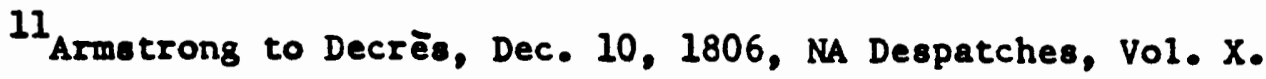
12 Ib1d.

${ }^{13}$ For text of the Convention of 1800 , see Hunter M1ller, ed., Treaties and Other International Acts of the United States of America, 
1776-1863, 8 vole. (Washington, D.C., 1931-1948), II, 457-487.

14 Decrès to Armstrong, Dec. 24, 1806, ASPFR, III, 805-806.

15 Armstrong to Madison, Dec. 24, 1806, with enclosures, M Despatchee, Vol. $\mathrm{X}$.

16

Anne1s, 9th Cong., 2nd sess., p. 72.

17 Entry for Friday, Feb. 13, 1807, Everett Somerville Brown, ed., William Plumer's Memorandum of the Proceedings in the United States Senate, 1803-1807 (New York, 1923), 610. See also Armstrong to Madison (private), March 29, 1807, NA Despatches, Vol. X.

18 Madison to Armetrong, May 22, 1807, NA Instructs., VI, 411-412.

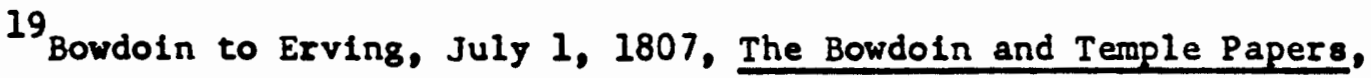
Part II, Massachusetts Historical Society Collections, 7th ser., VI (1906), 393-394.

${ }^{20}$ Adams, IV, 105-106.

2I Ibid., 62-63.

22 Ibid., 106.

${ }^{23}$ Armstrong to Madison, August 3, 1807, NA Despatches, Vol. X. 24 Ibid.

${ }^{25}$ Napoleon to Decrès, Sept. 9, 1807, as quoted in Adams, IV, 109. ${ }^{26}$ The crisis was due to the Chesapeake incident, accompanied by demands for war. Armstrong to Madison, Sept. 24, 1807, NA Despatches, Vol. X. See also M. Regnier to the Procureur Génèral, Sept. 18, 1807, ASPFR, III, 244. Armstrong informed American consuls that the decree was about to be literally executed. He feared that the moment this fact was known in England, it would have the effect of letting loose the ships of war and cruisers of that country on United States ships trading 
with France, Spain, Holland, and others as may be found within their reach. Under these circumstances, Armstrong advised that United States ships and other vessels in Europe should return as rapidly as possible to the United States. Armstrong Private Circular to U.S. Consule, Oct. 6, 1807, NA Despatches, Vol. X.

${ }^{27}$ Armetrong to Madison, Sept. 24, 1807, NA Despatches, Vol. X. 28 Ibid.

29 Jean-Baptiste Nompère De Champagny, Duc De Cadore. Although Talleyrand had been made Prince Benevento and Vice-Grand Elector of the Empire, he and Napoleon could no longer function together as the Emperor's power increased so much that no minlster could oppose his wishes. Desplte all of this, Talleyrand disagreed with and disapproved of the Emperor's course. His successor, Champagny, neither suggested a pollcy of h1s own, nor presumed, as Talleyrand sometimes dared, to argue with Napoleon. Adams, IV, 108.

30 Champagny to Armstrong, Oct. 7, 1807, ASPFR, III, 245. ${ }^{31}$ Armstrong to Madison, Oct. 9, 1807, NA Despatches, Vol. X. 32 Armstrong's lack of officlal information as to what was happening in London was a handicap to him. He did not receive any correspondence from Pinkney, American minieter to London, for many weeks. Armstrong interpreted this as a bad sign.

${ }^{33}$ Armstrong to Champagny, Oct. 9, 1807, NA Despatches, Vol. X. ${ }^{34}$ Armstrong to Madison, Oct. 15, 1807, with enclosures, NA Despatches, Vol. X.

35 Armetrong to Champagny, Nov. 12, 1807, NA Despatches, Vol. $x$. Melvin, 39, states that these reports, along with Champagny's confirma- 
tion of the stricter enforcement of the decree, contributed to the adoption of the American Embargo Act.

${ }^{36}$ Armstrong to Champagny, Nov. 12, 1807, NA Despatches, Vol. X. 37 Ibid.

38 Ibid.

39 Ibid.

40 Ibid.

${ }^{41}$ Ibid.

${ }^{42}$ Champagny to Armstrong, Nov. 24, 1807, ASPFR, III, 247-248.

43 Ibid.

${ }^{44}$ Alexander DeConde, This Affair of Louisiana (New York, 1976),

examines the expansionist tendencies of Jefferson which resulted in the acquisition of Louisiana and subsequent efforts to gain West Florida.

45 Armstrong to Madison, Nov. 15, 1807, NA Despatches, Vol. $\mathrm{X}$.

46 Armstrong to Monroe, May 4, 1805, NA Despatches, Vol. X.

47 Armstrong to Madison, Nov. 15, 1807, NA Despatches, Vol. X. 48 Jefferson was a dichotomist. He professed an abhorrence for war

and faith in peaceable economic coercion, yet he was also a territorial expansionist. He was, however, more realistic and flexible than his successor.

49 Armstrong to Madison, Nov. 15, 1807, NA Despatches, Vol. X. 50 Adams, IV, 113.

51 Armstrong to Madison, Nov. 15, 1807, NA Despatches, Vo1. X. 52 Ib1d.

${ }^{53}$ Adams, IV, 125. Text of the Nov. 11, 1807 Order in Counc11 found in ASPFR, III, 269-270. 
CHAPTER IV

CONTINENTAL SYSTEM ENFORCED

On January 7, 1807, Great Britain had issued an Order in Counc11, nominally in retaliation for the Berlin Decree. This applied a new interpretation of the Rule of 1756 to the subject states of France. It prohibited neutral trade between all enemy ports, for example, between Spanish and French ports (such trade had been definitely open before the outbreak of the war) and other ports from which British goods had been excluded by the Berlin Decree. On November 11, 1807, another group of Orders in Counc1l were lssued. They, and other ParIimentary enactments, declared that enemy countrles and their colonies were to be considered blockaded in the strictest manner. All goods coming from those countries, as well as any vessel trading with them without a special British license--together with its cargo--was to be fair prize. The effect of this order was to leave American trade with the West Indies unmolested, but to compel all exports from parts of the United States to Europe to be subject to British control, 11cense, and toll. 1 These measures were considered justifiable because the neutral states had acquiesced in the provisions of the Berlin Decree. This was erroneous. 2 In a letter of Nov. 27,1807 from Pinkney in London to Madison, the Minister stated:

The British orders annihilate the whole public law of surope relative to maritime prize, and substitute a sweeping system of condemnation and penalty in 1 ta place. The French decree produces no such change at all in that law. The last was no 
more than a legitimate, though possibly an ungracious, exerclse of the right of local soverelgnty; while the former can be referred only to forçe, and look for the scene of their operation to the ocean. 3

So long as the Berlin Decree was enforced only as a local or municipal law, the United States did not really remonstrate against it because it had not adversely affected her trade. Prior to November, 1807. there had been relatively little exhange of notes between France and the United States on the subject. Then word was received that the decree would be actively enforced without exceptions. 4

\section{MILAN DECREE}

Knowledge of events which led to Napoleon's decree from Milan, on December 17, 1807, is somewhat vague. It has been asserted that the retaliatory preamble of the decree was an after-thought, that there is evidence that the Milan Decree may not have been in Napoleon's original program, although it does seem consonant enough that he need not have based it upon British action. 5 It may very well be that the smperor had not even learned of the exact wording or even the actual promulgation of the November 11 Order in Council before issulng his first decree of Milan on November 23. He certainly had clear enough information of its likely character from various allusions in British newspapers, carefully excerpted by the Moniteur, and other French newspapers. On November 23, the very day of Napoleon's arrival at M1lan, he issued his first decree of Milan. 6 The fundamental measure in the new legislation of the extended Continental System was, however, Napoleon's second decree of Milan, Isoued from the royal palace on December 17, 
1807. Although this decree was ostensibly in response to the British Order in Counc1l of November 11, 1807, it was as much directed toward neutrals as it was toward the British. ${ }^{7}$

Iike the Berlin Decree, the preamble of this second decree of Milan, was a justification for its issuance. The British Ordere of November compelled the ships of neutrals and friends of England not only to submit to visits by British cruisers, but also to touch at British ports and to pay a tax levied upon their cargoes. According to the Milan Decree, the Britioh Orders would have the effect of denationaliz. Ing the vessels of all natione of Europe, affecting the sovereignty of the etates themselves. All ressels which submitted to search or entered Into British ports, became denationalized and, hence, were English property and subject to capture. Vessels either going to or coming from English ports, colonies or any country in the possession of English troops, were lawful prizes. The decree would not apply to such countries which forced England to respect their flags, and the decree should, by the very nature of 1t, be void as soon as the English Government would abide by the principle of the law of nations. 8 Armstrong quickly forwarded a copy of this second extraordinary decree to the secretary of state. ${ }^{9}$ Whether the decree was meant to stimulate Great Britain to comit new outrages, or to encourage the United States to denounce those she had already conmitted, the policy was so unwise that Armstrong reported he did not know a person who approved of 1t. Neverthelese, Armetrong was observant enough to know that it was equally as difficult to find a man who would dare hazard an objection to this Napoleonic measure. Even Talleyrand, who had been 
allowed to 80 farther than any other person, dared not give his opinion of 1t. Bad as he thought it was, he would not do more than to state that $1 t$ would appear to require come modifications. 10

In the postscript to his despatch, Armetrong reported that he had seen a letter from the Minieter of Marine, stating that the vessels of friendly and allied powers, then in the ports of the Empire, would not be permitted to depart until given further orders. This was supposedly to prevent their falling into the handa of the enemy. Armstrong clearly recognized the real object of this action--to induce the British to seize euch vessels of the United states as may be within their reach. "Thus the two rivale are to go on endeavoring which can most outrage lawe and juetice."11

Armetrong did not waste time in protesting this decree, which he realized posed obvious dangers to his country's Interests. At the same time, he saw an opportunity presented by Spain's impending doom to press France for help in the settlement of the Florida 1ssue. On December 23, Napoleon, In orders issued from Milan, ordered his Minister of War to concentrate armies to occupy the whole Iberlan Peninsula, and to establish the magazines for their support. He was almost ready to act against Spain, and his return to Parls on January 3, 1808, announced to those in on the secret, that the subjugation of Spain was about to begin. 12

Armstrong was one of the most interested in Par1s. He had longed eince 1805 for the chance to challenge the Emperor by employing oimilar presaure tactice. Armatrong belleved that Napoleon's achemes to defeat England required either control of or the acquiescence of North and South Amerlca 
in his plans. This factor would give President Jefferson the ability to demand rather than receive, terms for Florida. Whatever these terms might be, Napoleon would have to agree to them, or yield the Americas to England's naval supremacy. As Armstrong saw it, the plan was both safe and sure. Napoleon made no secret of his wants. Whatever finesse he may have used in the earlier stages of his diplomacy was thrown aside after his return to Paris on January $3 .{ }^{13}$ The Emperor wanted the United States to 80 to war against Great Britain. 14 He did not hesitate to threaten, cajole, or bribe. In response to Armstrong's remonstrances against the Milan Decree, the Emperor ordered Champagny to take a commanding and declarative position. He instructed Champagny to answer that:

.... am ashamed to discuss points which the injustice is 80 evident; but that in the position which England has put the Continent, I do not doubt of the United States declaring war against her, especially on account of her decree of November 11; that however great may be the evil resulting to America from war, every man of sense will prefer it to a recognition of the monstrous principles and of the anarchy which that Government wants to establish on the seas; that in my mind I regard war as declared between England and America from the day when England published her decrees; that, for the rest, I have ordered that the American vessels should remain sequestered, to be disposed of as shall be necessary according to circumstances. 15

Champagny followed the instructions of his master and wrote a note to Armstrong, dated January 15, 1807. He condemned the practices employed by Great Britain as so contrary to the rules of nations that, therefore, it had become necessary to turn against her the arms which she made use of herself. If inconveniences resulted then it was to England that the United States should direct complaints. The United States, more than any other power, had legitimate complaints againet Great Britain. 16 No doubt this was correct. Believing that the 
United States was ready to assoclate with all other powers who had defended themselves against Great Britain, the Emperor had not taken any definitive measures against American vessels which may have been brought into French ports. He had ordered that they should remain sequestered until a decision was made, according to the dispositions expressed by the government of the United States. 17

Responding to Champagny's letter of January 15, 1808, Armstrong, In a note of January 27, 1808, concurred with the French assessment of Anglo-American relations. If these two powers were not in a sate of open war, they were at least close to 1t. Armstrong further informed Champagny that he was cognizant that England was otrengthening herself In Canada, Nova Scotia, and her West India islands, and that she contemplated the selzure of the two Floridas. Under the circumstances, Armstrong felt the Emperor should be apprized of the intentions of the British, and at the same time that the United States would not be indifferent to the two provinces passing into the possession of a power on the point of becoming an enemy. The United States would repel every attempt made by Great Britain to possess these provinces. Armstrong reminded Champagny that in 1806 the United States had been on the point of eettling its differences with Spain by force, and was only restrained by the desire, repeatedly expressed by the Emperor, that a good understanding might be preserved between the two powers, and that the points in the controverey between them would be amicably discussed and terminated. Armstrong etated that he was for the last tme instructed to present the subject to the Emperor and to colicit his efforts at mediation in order to bring the parties into an immediate 
negotiation. This measure alone would prevent force. ${ }^{18}$

Armstrong's action at this time were extremely shrewd and adept. He was aware that the Emperor was, at that very moment, concentrating his efforts on Spain. Napoleon, ever expedient, also sought to achieve his objectives, trying to lure the United States into his scheme. On January 28, 1808, the Emperor gave the order to occupy Barcelona and the Spanish frontier as far as the Ebro, and to march a division from Burgos to Aranda on the direct road to Madrid. These orders were not disguised; they announced the annexation of Spain to France. A few days later, Napoleon began to dispose of Spanish territory as if it were his own. 19

On February 2, 1808, the Emperor Instructed Champagny to Inform Armetrong that whenever war should be declared between the United States and England, and when, in consequence of this war Americans should send troops into the Floridas to repulse the English, the Emperor would approve. Champagny was also to Inform Armetrong that, should the United States enter into a treaty of alliance the Emperor would be willing to intervene with the Court of Spain to obtain the Floridas for the Americans. 20

On the following day, Champagny sent for Armstrong and gave him this verbal message, and the Emperor's offer to intercede to settle the western boundary of Louisiana, on condition that the United States enter into an alliance with France. 21

Armstrong deserves credit for not merely accepting verbal assurances of the Emperor. Armstrong was determined to make sure that the French government was aware of what it needed to do to revive American 
friendship. He also wanted to place on record any official or unofficial overturee which had been made to him. Armstrong's correspondence clearIy demonatrates that he was not easily duped by professions of French friendship, and did not hesitate to impress the French government with his disgust and extreme displeasure for their past actions. Armstrong was certainly not intimidated by French officialdom. He bluntly accused France of violating certain neutral rights, and conmented to Champagny that it was indeed difficult to differentiate between the hostile actions of Great Britain and those of France. His irritation was clearly evident in the following:

I should little deserve, and still less reciprocate the frankness of this declaration, were I to withhold from your Excellency my belief, that the present conduct of France towards the comerce of the U.S., 80 far from promoting the views of his Majesty, are directly calculated to contravene them.

That the U.S. are at this moment on the eve of war with Great Britain on account of certain outrages committed against their rights as a neutral nation is a fact abundantly and even generally known. Another fact scarcely less known 1s, that, under these circumstances, France also has proceeded, in many instances and by various means, to violate these very rights. In both cases all the injunctions of public law have been equally forgotten; but between the two, we cannot fail to remark a conspicuous difference: with Great Britain the U.S. could invoke no particular treaty providing rights -upplementary to these injunctions.--But such was not their -ituation with France: with her a treaty did exist;--a treaty trengthened by time and confirmed by experience; a treaty stipulating the broad princlple, that free ships make free goods;--a treaty sanctioned with the name and guaranteed by the promise of the Emperor himself "that all its obligations should be inviolably observed."

I will not press the comparison farther, nor will I do more than suggest, that an open and unprovoked violation of existing engagements, cannot, in 1tself, but operate as a strong disuasive from new and more intimate connexions. 22

Armstrong perspicaciously suggested further that the professed

views of the Emperor would be most certainly promoted were all 
American property captured and held contrary to the provisions of existing treaties released, if any future outrage of these provisions forbidden, and if means for complying with the request made in his letter of January 28, 1808 adopted. 23

The tone and language of General Armstrong's correspondence with Champagny were certainly not what the Emperor expected, nor what he cared to hear, another example of the firmness which Armstrong maintained, when necessary, in his efforts to adequately represent the best interests of the United States. The Emperor responded in a similar fashion. He Instructed Champagny to write to the American minister that the treaty with the United States was founded on the principle that the flag covers the goods. If the United States submitted to the British Order in Council of November, then she would have renounced the protection of her flag. However, if Americans regarded this act as one of hostility, the Emperor was ready to do justice in every respect. 24

\section{CHOICE OF ENEMIES}

The documents in this exchange between Armstrong and the French government were forwarded to the Secretary of State. If American leaders were under any 111 usions about Napoleon's character, these should have been shattered when they read the despatches from Armstrong. He candidly expressed his opinions of Napoleon and Champagny, and did not hide the frustrations he had felt for quite some time. He bluntly warned his superiors to be cautious. Critically, but accurately, Armstrong described French actions: 
With one hand they offer us the bleselings of equal alliance agalnst Great Britaln; with the other they menace us with war If we do not accept this kindness; and with both they pick our pocket, with all imeginable diligence, dexterity, and Impudence. 25

Characteristic of Armstrong, he advised firmer action on the part of the United Statea. He encouraged the United States to make a choice between one enemy or the other--elther France or England; "but in elther case do not suspend a moment the seizure of the Floridas." 26 The United States was eventually to pursue this course of action, but not before many more case of national abuse. In his despatch of February 17. 1808, Armstrong expressed the hope that American policy, while being more temperate, would nonetheless be firm. This followed his explanation that the King of Holland had closed his ports to American commerce except during a sorm, and that while the etorm lasted, Americans were to be regarded as prisoners of war. To a man of Armstrong's sense of pride and justice, this behavior was "outrageous."27 On February 22, 1808, Armstrong once again Informed Madison about the enforcement of the French decrees agalnst the United States. He belleved that the two facts he mentioned would "sufficiently show the decided character of the Emperor's policy with regard to us."28 First, Armstrong informed Madison that, in a Council of Administration meeting It was proposed to modify the operation of the decrees, a proposition supported by the whole welght of the Counc1l. The Emperor, however, "became highly indignant and declared that these decrees should suffer no change, and that the Americans should be compelled to take the positive character, either of allies or of enemies."29

$$
\text { Second, on January 27, 1808, twelve days after Champagny's }
$$


witten assurances that these decrees would not alter the status of any sequestered property until diecussions with England were brought to a close, and seven days before he repeated to Armstrong these assurances, the Emperor had, by a opecial decision, confiscated two American ohips and their cargoes merely because they did not possess a document not required by any law or usage of the commerce in which they had been engaged. This was done on the basis of a report of sequestered cases, totalling up to 160. At the then current prices, that would amount to 100 million francs, a sum whose magnitude alone made all attempts at saving it hopeless. The principle sufferers from such action, as Armstrong recognized, would be the Danes, Portuguese and the Americans. Although Armstrong once more advised that the United States stand Its ground, Jefferson and Madison were preparing to respond more in line with their desire to avoid unpleasant confrontation. 30

\section{EMBARGO ACT}

While events were rapidly transpiring in Europe, newo arrived from the United States that Congress had passed the Embargo Act on December 22, 1807.31 This measure, along with simultaneous measures for defense which placed great rellance on gunboats, 32 actually hindered Armstrong's diplomatic efforts. In his instructions of February 8, 1808, Armstrong was officially informed of the passage of the Embargo on American ships, a result of the illegal and hostile actions of France and Great Britain against American comerce and navigation. The Adminietration saw the Embargo as the means best ouited for the crisis. It was thought to be effective security for American mercantile policy 
and for mariners then at home, and those who were daily arriving. At the same time, it was not a measure of, nor a fust cause for war. HavIng been informed of the passage of this act, Armstrong officially made it known to the French government. In describing the act, the Secretary of State had written that it was:

...strictly a measure of precaution required by the dangers incident to external comerce, and being indiscriminate in its terms and operation toward all nations, can give no just offence to any. The duration of the act is not fixed by it-elf; its causes in a degree sufficient in the judgment of the Legislature to induce or forbid its repeal. It may be hoped that the inconveniences felt from it by the belligerent nations may lead to a change of the conduct which imposed the inconveniences of it on itself. 33

For Jefferson and the Republicans the Embargo Act was the alternative to war, indicative of their faith in the principle of peaceable economic coerclon. Despising war and large standing armies and navies, advocates of peaceable coercion believed that they could achieve their objectives without the need to risk one's country in costly and bloody wars.

The President resorted to the use of the Embargo as a last alternative when diplomacy appeared to have falled. The Chesapeake incident of June, 1807, the fallure of the Monroe-P1nkney talks to resolve serfous matters of commerce, the British announcement of their Orders In Counc1l of November, 1806, and January, 1807, and other British outrages, plus news of France's retallatory decrees, forced the Adminietration to use means just short of war in hopes that the belligerente could be encouraged to desist from their violatione of international law.

If Jefferson had wanted, he could have had a war against England, 
as the country was in an inflanmatory mood. However, without an adequate navy, and with an exposed coastilne, war seemed foolhardy to him, as well as contrary to his beliefs and general abhorrence for war. ${ }^{34}$ Instead, Jefferson tried to use the Chesapeake affair as a veapon of peaceable economic coercion. Jefferson thought the measures employed by the Administration in the form of economic coercion would bring about the desired changes in Great Britaln's conduct. On July 2, 1807, he had 1ssued a proclamation forbldding the British to use American territorlal waters and ports for provisioning. ${ }^{35}$ On December 14, 1807, the previousIy suspended Non-Importation Act was finally allowed to go into effect, al though it was not strong enough to force concessions from the belligerents. 36

Having recelved news of the British Orders in Council and of the French decrees, it was necessary for the President to act. Jefferson honestly belleved that the Embargo was, in Itself, a form of resistm ance. ${ }^{37}$ Although considered an alternative to war, it entalled most of the miseries of war, without any of 1 ts compensations. 38

The Embargo as a means of coercion obviously falled. 39 Perhape the most important consequence of the Embargo was the divisive spirit it created in Americans. It gave rige to omuggling and produced outright condemation from many of the country's leading politiclans-especially those from New England where the effect was felt the hardest. 40 The opposition towards the Embargo became increasingly loud, until the Embargo was repealed in the final days of the Jefferson Adminietration.

In theory, the Embargo and 1ts subsequent Supplementary Acts were impartial, but in practice, it was directed mainly towards Great 
Britaln. Jefferson had always been susplcious of British aims. Deoplte the harm the Prench decrees caused Americans, Jefferson never really believed the contest in Europe was between tro countries of equal etrength, especially after Loulsiana had been ceded to the United states, and after France had lost its fleet at Trafalgar. After these events, France appeared to Jefferson as much less threatening than did Great Britain. After all, Great Britain had control of the 8eas, she had the means through her American basea to insult, plunder, or attack the United States, and she had the motive of revenge to. encourage her host1lity. Jefferson's susplclons of British motives should not, then, be underestimated. Her insolent behavior was an important factor in Inducing Jefferson to choose a weapon that accommodated the war aims of Napoleon. 41 Despite Jefferson's efforts to discount this, the Embargo Act was viewed as a pro-French measure by many in and out of Congress. In the Embargo Message, the President tried to emphasize the new construction of the Berlin Decree as if the Embargowere intended to be directed against France. This was dellberately misleading. 42 The President knew that one of the first effects of the act would be to give some teeth to the Non-Importation Act which had gone into effect on December 14, 1807. The President believed that If Great Britain were deprived not only of food imports, but also of raw materials for industry, powerful British manufacturers would force the goverment to yleld to American demands. One of the President's objectives was to strike a blow at Britaln without comitting the United states to war, and without acquiring the label of being a French agent. 43 
Jefferson, however, was not successful in hiding his intentions from the Federalists. Many of them knew from the beginning the true significance of the Embargo. On the very day of 1 ts passage, Representative Samuel Taggart expressed his apprehensions about the effects of the Embargo:

Last night precisely at eleven o'clock we closed a session which had been held for three days in secret. Should I say that the die is cast, that my country is no longer independent; we have been legislating under an imperial decree of the Emperor of France and sanctioning a plan matured in Paris it would be saying no more than I fear will be reallzed. 44

Jefferson, then, was fully aware that the Embargo constituted a service to Napoleon, and as much as admitted that it vould not hurt France. The President reassured the French minister, Turreau, of the Embargo's effect. "The Embargo which appears to hit France and Britain equally," Jefferson said to Turreau, "1s for a fact more prejudicial to the latter than the other by reason of a greater number of colonies which England possesses and their Inferiority in local resources." 45 Unlike Great Britaln, France was reasonably self-sufficlent and could get most of the supplies which she needed from her continental satel11 tes. 46

Because Jefferson viewed France as not posing an imnediate threat to American security, he saw the Embargo as an offensive as well as a defensive weapon. ${ }^{47}$ In his resistance to England, Jefferson undoubted1y hoped that Napoleon would favor American ambitions to the south, especially the Floridas, 48 a hope based on the Emperor's promise to General Armotrong that if the United States made an alliance with France againat Great Britain, Jefferson would be free to intervene in Spanish 
America. 49

In this dangerous game of diplomacy, Jefferson was outplayed by Napoleon. The Embargo Act, Intended as a fair trade for the Floridas, In effect made the United States an ally in the Continental system, wthout help in acquiring one square foot of Florida in return. The Emperor's price for his cooperation kept rising, desplte Jefferson's objections to the treatment accorded him. 50

Although the Embargo Act actually favored Napoleon's Continental Syatem, this should not be interpreted to mean that Jefferson or the Administration cared for Napoleon. In fact, just the opposite was true. Jefferson wote of Napoleon:

...Bonaparte was a lion in the field only. In civil life a cold-blooded, calculated, unprincipled usurper, without a virtue: no statesman, knowing nothing of commerce, political economy, or civ1l government, and supplying ignorance by bold presumption. I had supposed him a great man until his entrance Into the Assembly.....From that date, however, I set him down as a greet scoundrel. 51 
Notes

Chapter IV

I $_{\text {ASPFR }}$ III, 5, 269-270. An additional series of orders in Council also followed those of Nov. 11, 1807 on Nov 25, 1807.

2 stockder, 500 .

3 Pinkney to Madison, Nov. 23, 1807, ASPFR, III, 203-206.

4 stockder, 501.

5 Melvin, 41.

6Ibid., 41-43.

7 Perkins, 70 .

8 ASPER, III, 290-291.

9 Armstrong to Madison, Dec. 27, 1807, NA Despatches, Vol. X.

Received in Washington, D.C. on March 26, 1808.

10 Ibid.

11 Ibid.

12 Adams, IV, 291.

13 Ibid., 291-292.

14 Armstrong to Madison, Jan. 22, 1808, with enclosures, NA

Despatcheo, Vol. XI; Champagny to Armstrong, Jan. 15, 1808, ASPFR, III, 248-249.

15 Napoleon to Champagny, as quoted In Adams, IV, 292.

${ }^{16}$ Champagny to Armetrong, Jan. 15, 1808, ASPFR, III, 248-249. 17 Ibid. 
${ }^{18}$ Armstrong to Champagny, Jan. 27, 1808, N Despatches, Vol. XI. 19. Adams, IV, 293.

20 Napoleon to Champagny, Feb. 2, 1808, as c1ted In Adams, IV, 293. ${ }^{21}$ Armstrong to Madison, Feb. 15, 1808, NA Despatches, Vol . XI. 22 Armetrong to Champagny, Feb. 5, 1808, NA Despatches, Vol. XI. 23 Ibid.

24 Napoleon to Champagm, Feb. 11, 1808, as cited in Adams, IV, 295. 25 Armstrong to Madison, Feb. 15, 1808, M Despatches, Vol. XI. 26 Ibid.

27 Armstrong to Madison, Feb. 17, 1808, NA Despatches, Vol. XI. 28 Armstrong to Madison, Feb. 22, 1808, MA Despatches, Vol. XI. 29 Ib1d. 30 Ibid.

31 Annals, 10th Cong., 18t sess., pp. 2814-2815; Armetrong to Champagny, Feb. 8, 1808, M Despatches, Vol. XI.

${ }^{32}$ Annals, 10th Cong., lst sess., P. 2814. Intricately associated with Jefferson's ideas of peaceable coercion and dread of war, was his detest of large standing armies and large navies. To him, these were sources of repression in a democracy, as well as an expensive financial drain. In 1806 the navy had only one frigate in active service. When it appeared that need for protection of American shores and rivers was iminent, Jefferson turned to the construction of gunboats which he prized highly. They were cheaper, supposedly effective for defense, and lese likely to involve America in ware. On Dec. 18, 1807. Congress authorized bullding, purchasing, arming or equipping, a number of gunboats, not exceeding 188, for the protection of the ports and 
harbors of the United States. Perkins, 51-52, states:

The fallure to develop military defenses, like the policy of rigorous financial retrenchment, undermined the effectiveness of American protests before 1812, convinced Britain she need never fear more than an ineffectual war against her, and cost the United States heavily when war came. In precisely those areas most requiring flexibility, Jefferson and his followers proved most rigid.

A.T. Mahan, Sea Power in Its Relations to the War of 1812, 2 vols. (London, 1903), I, 74-75, states that if Robert Morris' navy of twenty ships-of-the-1ine which he suggested in 1794, had existed in 1800, there probably would have been no war of 1812--that 18, if Jefferson's passion for peace and abhorrence of navies could have been left out of the account. See Jefferson's Message to Congress of Feb. 10, 1807, James D. Richardson, ed., A Compllation of the Messages and Papers of the Presidents, 1789-1897, 20 vols. (Hew York, 1897-1917, I, 407-409; hereafter cited as Richardson; for an expression of Jefferson's views on the efficacy of gunboats.

${ }^{33}$ Madison to Armstrong, Feb., 1808, iA Instructs., VI, 443-447. For thorough examinations of the Embargo, see Louls Martin Sears, Jefferson and the Embargo (Durham, N.C., 1947); Walter Wilson Jennings, The American Embargo, 1807-1809 (Iowa City, 1921).

${ }^{34}$ Alexander DeConde, A History of American Foreign Policy, 2nd ed. (New York, 1971), 93.

${ }^{35}$ Richardson, I, 410-412.

${ }^{36}$ Perkins, 113, states :

...the Nonimportation Act of 1806 was worse than useless. When at last seriously enforced in the spring of 1808, nonimportation became an important ancilliary to the Embargo, but the passage in 1806 of weak legislation to take effect only after month of delay was neither an effective act of coercion nor a wise prelude to friendly negotiation. 
37 Mahan, I, 187, 1s extremely critical of the Embargo. 38 Ibid., 185.

39 Perkins, 265; Jennings, 193; A.L. Burt, The United States, Great Britain and North America: From the Revolution to the Estab1ishment of Peace After the War of 1812 (New York, 1961). 40 Jennings, 231. Burt, 261, states that the Embargo falled because it did the most damage to the nation it was supposed to protect. 41 Lawrence S. Kaplan, "Jefferson, the Napoleonic Wars, and the Balance of Power," W11liam and Mary Quarterly, 3rd.ser., XIV (1951), 198; . DeConde, History, 94; Bemis, History, 151; and Perk1ns, 150, all support the contention that the Embargo was directed primarily at Britain, therefore it aided France.

${ }^{42}$ Three out of four documents attached to the President's message dealt with French violations of American neutrality. Kaplan, "Jefferson, the Napoleonic Wars...," 201.

43 Ibid.

${ }^{44}$ Taggart to Taylor, Dec. 22, 1807, George H. Hanes, ed., "Letters of Samuel Taggart, Representative in Congress, 1803-1814," American Antiquarian Soclety Proceedings, new ser., Part 1, XXXIII (1923), 223. T. Pickering to R. King, Jan. 2, 1808, Charles R. King, ed., The Life and Correspondence of Rufus K1ng, 6 vole. (1894-1900; rpt. New York, 1971), v, 46.

${ }^{45}$ Turreau to Champagny, June 28, 1808, as quoted In Kaplan, "Jefferson, the Napoleonic Wars..., ", 201.

47 Ibid., 202.

${ }^{48}$ Ibld., 202-203; Perkins, 149. 
${ }^{49}$ Armstrong to Madison, Feb. 15, 1808, MA Despatches, Vol. XI; Kaplan, "Jefferson, the Napoleonic Wars...," 203n. This promise was made before Napoleon knew of the Embargo.

50 Kaplan, "Jefferson, the Napoleonic Wars....," 203.

51 Jefferson to John Adams, July 5, 1814, Writings of Jefferson, VII, 461. Albert Gallatin placed no more confidence in Napoleon to modify his measures, perhaps even 1 ess than in Great Britain to modify hers. He stated: "The only difference in his favor, and it arises probably from Inability alone, is that he interfers not with her domestic concerns." Gallatin to Charles Pinckney, Oct. 24, 1808, Henry Adams, ed., The Writings of Albert Gallat1n, 3 vols. (Philadelphia, 1879), I, 419. 
CHAPTER V

CONTINENTAL SYSTEM INTENSIFIED

While President Jefferson struggled with Congress over the Embargo Act and defense measures, Napoleon occupled himself with dismantifng Spain. ${ }^{I}$ Lacking epecific instructions as to the course he should follow, Armstrong persisted in his protests to Champagny by using the argument that the decrees themselves were being violated. In a note of March 1, 1808, he protested the violation of articles 76, 79, and 80, In the case of the br18, Mercury, captured by a French privateer. His firmness cannot be missed in his notes to the French Minfster of Forelgn Relations. He boldly warned Chamagny:

I cannot close this detall whout the most serlous remonstrances against abuses so revolting--so multiplied and so injurlous to the rights of American comerce... their perpetration and continuance cannot fall to Interrupt that good understanding which has so long subsisted between the two powers which has been productive of nothing but advantage to both and which of course would be most unwisely exchanged for the plllage of a few trading vessels. 2

Armotrong's diligence in the pursuit of American Interests is demonstrated by the fact that, prior to his recelpt of official inetructions, dated February 8, 1808, ordering him to formally protest the BerIIn and M1lan Decrees, ${ }^{3}$ Armotrong had already written at least twenty notes of proteet and inquiry pertaining to cases which had arisen under the Berlin and Milan Decrees. After recelving his Instructions, Armstrong further denounced these decrees as violations of the treaty exioting between the United States and France. 4 He did 
not waste time in presenting a note to the French government which he hoped would obtain elther a recall of the 11 legal measures, or at least leave in force the rights which accrued to the United States. He did not immediately receive an answer to this note, nor did he expect one, as the Emperor had left for Spaln. At no time before his departure had Napoleon indicated any change in the views which had originally produced the Beriln and Milan Decrees. 5 Armetrong understood all too well that with Napoleon's activities in Spain, as vell as his apparent success throughout the Continent, the United States must necessarily be brought more etrictly into Napoleon's fold. Armstrong did not have much optimism at this point in his efforts to alter Napoleon's decrees as they affected American commerce. General Armstrong's protests and effectiveness were further undermined by the American Embargo Act. It was difficult to protest the capture of American ships when they were not legally in French waters in the first place. This predicament was exploited by Napoleon as he calculated his next move.

\section{BAYONNE DECREE}

During the two or three months following the abdication: of Spain's Charles IV, Napoleon was at the sumit of his ambitions. The Emperor was further engaged in gradiose plans that he hoped would secure England's destruction and achleve his world empire. The English navy and English comerce were to be driven from the Mediterranean Sea, the Indian Ocean, and American water. Orders were quickly 1ssued for the reconstruction of the navies of France, Spain, and Portugal. Great expeditions were to occupy Ceuta, Egypt, Syria, 
Buenos Aires, and the Isle de France. 6

To obtain these objectives, the Empire needed not only the submission of Spain, but also the support of Spanish America and the United States. Napoleon saw his opportunity to use the American Embargo as a means to accomplish his own purposes. 7 on Apr 11 17, 1808 , he issued an order that all American vessels entering the ports of France, Italy, and the Hanse towns, be selzed. This order was known as the Bayonne Decree. The ostensible reason for 1 ts 1 ssuance was that because of the American Embargo Act, ships that violated this law were, In reality, English ships that pretended to be American. Even Armstrong termed Napoleon's reasoning as "very ingenious." 8 His protests against this type of reasoning were fut1le. 9 After a glimer of hope that the system with regard to the United States might be ameliorated, Armstrong's despatch of June 6, 1808, announced to Mad1son that several American ships had been condemned by the French Councll of Prizes. 10 Despite the rapid pace of events in Europe, it was not until May 2, 1808, that Madison finally sent instructions to Armstrong that were Intended to guide him through the dangers of Napoleonic diplomacy. 11 Madison informed Armstrong that the Administration did not appreciate Napoleon's efforts to coerce the United States into joining France in a common effort. He stated that the notion that France had presumed to declare war against Great Britain for the United States had created quite a sir. He further added that:

To present to the United States the alternative of bending to the views of France against her enemy, or of incurring a confiecation of all the property of their citizens carried into French prize courts, implied that they were susceptible of Impressione by which no independent and honorable nation 
can be guided; and to prejudice and pronounce for them the effect which the conduct of another nation ought to have on their Councils and course of proceeding, had the alr at least of an assumed authority, not less irritating to the public feeling . 12

Madison replied that the United States, while acknowledging the inducement offered by France in the event of war with Great Britain to interpose with Spain to obtain the Floridas, had chosen, nonetheles, to pursue a policy of neutrality. However, in what was obviously designed to appease the Emperor, the Secretary of state stated that, In the event such a crisis demanded that the United States take a precautionary occupation of the Floridas against the hostile designs of Great Britain, "1t w11l be recollected with satisfaction that the measure had been contemplated with approbation by His Imperial Majesty. "13

Included in the despatch of May 2, 1808--received in Paris on June 8--was information relating the passage of the act which gave the President the authority to suspend, whole or part of the Embargo laws. 14 The conditions on which the suspending authorlty was given to the President claimed Armstrong's particular attention. The American government was appealing equally to the justice and the policy of both belligerents. Madison Informed Armstrong that the President counted upon him to apply his best efforts to make this appeal as impreselve to the French government as possible. ${ }^{15}$ According to the Administration, it was only sound policy for France to rescind at least that part of her decrees which violated neutral righte, and to be the first one of the two belligerents to take that step. It was also reasonable to expect that this step would be imnediately taken, 
although the total repeal of her decrees was to be more reasonably expected, especially if Great Britain repealed or wae likely to repeal hers. ${ }^{16}$ The Administration continued to believe that Napoleon could be brought to reason. Th1s was an error Jefferson and Madison consistently made.

The Emperor and Champagny were still in Bayonne when Axmstrong received a note from the latter, dated June 13, 1808, from which Armstrong Inferred that the Emperor had taken the American refusal of an alliance with relatively good humor, further evidenced by an order to the Council of Prizes to suspend their proceedings againet American cases. ${ }^{17}$ Being oomewhat encouraged by this, and at the same time seeing: an opportunity to press American objectives with regards to Florida and the western boundary, Armstrong took the occasion to address a letter to Plerre de Cevallos, Joseph Bonaparte'o Minister of Forelgn Relations. 18 In so dolng, Armstrong pursued an avenue which had previously been closed by the obstinancy of Godoy and the former king, Charles IV. This was a shrewd move on the part of the American minister, who also forwarded a copy of his full authority to negotiate with spain. 19

In the short time following Champagny's letter of June 18, 1808, however, Napoleon appears to have had a change of heart, having had time to reflect more carefully on coming events-owhich looked rosier now that his brother, Joseph, was on the throne of Spain. There no longer appeared to be a reason to appease the United States. The Emperor, therefore, instructed Champagny to inform Armstrong that:

...you do not know what he means about the occupation of the Floridas; and that the Americans, being at peace with the Spaniards, cannot occupy the Floridas without the per- 
mission or the request of the king of Spain. 20

Champagny, obligingly, wrote a note to Armstrong, dated June 22, 1808, reflecting a marked change in temper from his previous note of June 18. 21 That Armstrong was somewhat dumbfounded by ouch a denial, is stating it mildiy, although Armstrong had experienced Napoleon's duplicity before. No wonder Armotrong had demanded that official or unofficial overtures from the Emperor be put in writing. He had wisely prepared for this possibility. The letter of June 22 not only retracted the promise of approving the cautionary occupation of the Floridas by the United States, but it also asserted that the Emperor's message of February 3, 1808, had been misunderstood. 22

Champagny found himself in an embarrassing situation not unlike that of his predecessor. ${ }^{23}$ Armstrong immediately reminded Champagny of the written explanation Champagny had given himself on this very subject, in which the only stipulated condition for such an occupation was an attack or demonstration of attack by Great Britain. There was not a single syllable mentioned about either the privity or the consent of the king of Spain, both of which were now deemed necessary. 24 The general would have been completely justified in calling both Champagny and the Emperor Ilars, and he must surely have held this opinion of them. Armstrong's perspicaclousness in analyzing the effects of military and political events on French policy with regard to the United States was clearly evident when he ascertained that the ideas expressed by Champagny had no doubt resulted from the new relationship which the Floridas represented to the. French government. The abdication of Charles IV and the assumption of the throne by the Emperor's 
brother, Joseph, clearly had changed the situation. 25

On July 4, 1808, General Armstrong, as instructed, again protested the position in which the Emperor had placed the United States. Choosing between an acquiescence to the views of France against Great Britain, and a confiscation of all American property sequestered by order of the Emperor, was equally of fensive to both governments. 26 The Bayonne Decree was, in effect, a declaration of war against American commerce. It increased seizures of American vessels, and contributed to other outrageous behavior, such as actually burning American ships, which Armstrong protested vehemently. 27

Writing to the Secretary of state on July 26, 1808, Armstrong informed Madison that his orders of May 2, 1808, with regard to the Emperor's proposition of February 3, and the other related in Champagny's letter of January 15, had been executed. Although it would have given him the greatest pleasure to have received from the French government explanations on the subject of the differences between them that would have satisfled the views of the United States, he could not report that this had occurred.

...I owe it as well to you as to myself to declare that every attampt for that purpose, hither to made, has falled, and under circumstances which by no meang indicate any change, in this respect, for the better. 28

The same spirit was reflected in a letter to President Jefferson two days later, in which Armstrong stressed again that France did not seem disposed to change her eystem. Indeed, Armotrong correctly assessed that she was much attached to 1t. Calling French logic "madness," Armstrong reported that the Emperor had declded to identify 
American commerce with that of England. 29

\section{RETREAT TO BOURBON d' ARCHAMBAULT}

General Armstrong was pessimistic that any satisfactory response from the French government would be forthcoming. H1. frustration was further compounded by the fact that the American government had consistently disregarded his advice to employ firmer action to acquire American territorial objectives or to uphold American honor. Once again, Armstrong called for more forceful measures in 11ght of cont1nued French and Spanish abuses. If the time had not yet cone to selze Cuba, as the President had once advocated, then it would never come. A set of clrcumstances 80 favorable to that object were not likely to occur again. 30 In this assessment, Armstrong was no doubt correct. Frustrated that his advice was not followed, and possessing little hope for a change in the Emperor's system, Armetrong, suffering with a bad case of rheunatiam, decided to leave Paris for the baths of Bourbon d' Axchambault, 150 miles from Paris, where he stayed until fall. 31 The Court had left Bayonne on July 20 and 21. The Emperor was expected at Nantes on August 7 and at Ramboulllet on August 13, and it was doubtful he would even touch at Paris. If he should, then Armstrong would endeavor to draw from him an answer to the remonstrances which he had made at various times since November, 1807. He then retired to await further Instructions from Madison. 32

As Armstrong left Paris for Bourbon d' Archambault, he left notes with his secretary for Champagny, in which he desperately tried to impress upon the French the many disadvantages of bad relations between 
the United States and France. Armstrong instructed his secretary to express Armstrong' : regrets to Champagny that Franco-American relations were far less than what they should be. He believed that the Emperor certainly had a right to make any municipal regulations he deemed proper. For example, it was within his right to deny entry into the ports of France to American ships which had touched in England, or were destined for that country, and he could either sequester or confiscate auch vessels of the United States as should Infract those laws, after due promulgation and notice. Beyond this, however, the United States hoped and belleved that the Emperor would not 80.33

While Armstrong was at Bourbon d' Archambault, he received Madison's instructions of July 21, $1808 .^{34}$ In this set of instructions Madison referred to the cases of the burned American vessels which Armstrong had reported in his letter to Champagny of April 2, 1808. According to the Secretary of State, if ample reparation should not have been made, the President thought it proper that Armstrong should remonstrate "In terms which may awaken the French government to the nature of the injury and the demands of justice." 35 Armstrong had already addressed this question and had failed to receive a satisfactory response. Armstrong exercized his independence as a Minister Plenipotentiary, and declined to press the French government further on this point by going to Paris to renew discussions with Champagny as suggested by Madison in his instructions. ${ }^{36}$ In not fulfilling this portion of his Instructions, Armstrong was completely justified. It would have been useless and possibly even injurious to the American position. 37 
Armstrong also informed the Secretary of state that the St. Michael had returned from England and brought with her accounts which left no confidence in a change in the system on that oide of the Channel either. To keep this fact a secret from the French government was an Impossibility. Knowledge that England and the United States were at odds almost excluded the possibility of an adjustment between France and the United States, since this fact would tend to cause the French to extend their policy. ${ }^{38}$

Although Armstrong had earlier thought that an Embargo might have been appropriate against the belligerents, by the end of summer he clearly recognized that the Embargo was a fallure, as it had not achieved 1ts objectives in Europe. Th1s assessment must have been unsettling to Jefferson and Madison who were experiencing rapidly increasing domestic opposition to 1t, and were burdened with the problems of trying to enforce a measure so blatantly ignored by American shippers, despite the risks of capture, forfelture, and even burnings. Armstrong stated:

We have somewhat over-rated our means of coercing the two great belligerents to a course of justice. The embargo is a measure calculated, above any other, to keep us whole and keep us in peace--but beyond this you must not count upon it. Here it is not felt, and in England [in the midst of the more recent \& interesting events of the day] it is forgotten. By the way--the Emperor would prefer 1t, a war on our part with G.B.; but woulghprefer 1t, to any state of things, except that of a var.

Armstrong recognized that the Emperor--although hostile to the Frobargo originally--had concluded that it was indeed a hostile act toward Great Britain which alded his Continental system, ${ }^{40}$ in spite of the fact that the Embargo did adversely effect some French colonial 
trade, especially in the West Indles. 41 In the Fall of 1808 , the Emperor gave h1s approval to the Embargo. He was, in fact, upset when the Embargo was eventually repealed at the end of the Jefferson Administration. The official report, largely in the Enperor's words, stated:

The Americane, a people who owe their fortune, prosperity, and almost their existence to comerce, have given the example of a great and courageous sacrifice. They have forbidden.... all commerce... rather than shamefully submit to the tribute which the Engliah attempt to impose upon the navigators of all nations. 42

Armstrong once again urged the United States to take firmer action. Unless France did the United States justice, the Embargo should be raised and commercial vessels should be armed. His remarks were almost pleas for action, if only to show the world that the United States would not allow 1tself to be pushed around without at least making a symbolic gesture of resistance. He further argued that:

Should she adhere to her wicked \& foolish measures, we ought to content ourselves with doing this. There 18 much, very much besides, that we can do, and we ought not to omit doing all we can;--because it is believed here, that we cannot do much, and even, that we w11 not do, what we have the power of doing. For God's sake let your measures be auch, as will correct this erroneous estimate of both your power and your spirit. 43

The Administration again shled away from taking a firm etand, convinced the arming of merchant ships would inevitably lead to war with one belligerent or the other. 44 Despite rapidly growing domestic opposition in the United States to the mbargo, the Administration, lacklng what it saw as alternatives, clung to the Embargo. The only other alternative appeared to be war, and Madison abhorred the thought. 45 
Having spent almost four years in France by this time, Armstrong had experienced the difficulties of conducting diplomacy with Napoleon's government, and his position was made even less desirable by the Administration's refusal to accept his advice. Additionally, Armstrons learned that many of his confidential letters to Madison had been published by Congress, This damaged his position, since the French goverment was allowed to know his confidential oplnions regarding Franco-American relations. Some of his French sources, fearful of being exposed, dried up, thereby depriving Armstrong of valuable inside information. 46 Falling to see a prospect for change in France's conduct, and becoming increasingly distliustoned with his misolon, General Armstrong began to believe there was no reason to continue keepling a minister in France. H1s despatches more frequently expressed his desire to return to the United States, at the President's approval--delayed on several occasions in order to pursue some new possible break-through. 47

At the time he wrote his despatch to Madison of August 30, 1808, stating that the United States had over-rated 1ts ability to pressure France to alter her pollcies, Armstrong was not aware that his last note to Champagny, plus certain effects of the Embargo, actually helped to produce a reconsideration of French policy. ${ }^{48}$ On September 11, 1808, Collins de Sus8y, the Director General of the Customs, presented a report to Napoleon on the neutral situation, especially that of the Americans. In this report Collins held that: (1) it would be useful to hold in French ports the American vessels which arrive in ballast, then load with goods useful to England, and (2) it was desirable 
to cause the arrest of all Americano who navigated in Europe. Direct evidence 1s lacking as to the preclee circumstances which produced this letter, but its connections with the Bordeaux petition and Armstrong's note of early Auguet are obvious. 49

On September 15, 1808, Napoleon referred this report to Decrès for his opinions. Decrès took lesue with Collins for reasons which are an interesting application of Armstrong's views. He stated that there was no doubt the Americans arrived in France only under a ifcense of the King of England. It was a requirement of the Order in Council of November, 1807, which could not be evaded by the Americans unless the Order was a dead letter. That they were still in force was shown by the strictness of the blockade and by the arrival, on September 13, of the ship, Junot, with a British 1icense. Decrès recognized possible advantages to the state. Since the said vessels came in ballast, France received payment for her goods without any French money being paid out In return--certainly the most advantageous arrangement a comercial state could desire. He urged ignoring the actions toward the neutrals who came in ballast into french ports. It was only necessary to enforce measures on those who should be convicted for violating the decree of blockade by trading in English goods. However, it would be important to authorize not only the Americans, but all those who wished, to export French surplus of wines, grains, brandy, and the products of manufacturing. The dignity of the decree would, therefore, not be violated in the least, since it would be executed in all its forms. Not only would there be more money brought into France, but French farmers and producers would also benefit. 50 
Decrès also disagreed with Collins that Congress would thank Napoleon for the "competition" in enforcing the American Embargo. He belleved that it was not in the interests of the Emperor to selze Americans on the open seas. He further argued against the new rigors of the blockade which would deprive the allies of the Empire of the only outlet for their products, and the only cource for their supplies. Yet he did hold that just reciprocity demanded the application of the Berlin and Milan Decrees to those neutrals who went to the ports of the enemy or the enemy's allies. On this last point, which Decrès was inclined to adopt, Napoleon asked for a further report, which appears not to have been presented when he departed for Germany on September 22.51

Armstrong, in a private letter of October 20, 1808, wrote to Madison that Napoleon seemed to be serfously re-considering FrancoAmerican relations. "His Majesty was disposed to remove all difficulties between the U.S. and France but that time was wanting at the moment to enter upon the business." 52 However, when Napoleon returned from Erfurt, it was when he was deeply involved with the business of Spain, and establishing greater vigilence in enforcing the Continental System toward neutrals. Yet, like all the other quickly abandoned experiments of 1808 by which Napoleon sought to alleviate the pernicious effect of the strict interpretation of his system in France, the freer trade policy urged by Decrès marked the certain trend toward a oystem of exceptions-a trade by special 11censes. 53 There is evidence that Napoleon had not achleved his aims. He had falled to secure effectual co-operation in enforcing his interpretation of the system. 54 
Shifting to the license trade was an undeniable break with the Continental system. 55 Armstrong, therefore, had come closer to achleving greater auccess than even he had Imagined. Had it not been for the peculiar military circumstances of the moment, it is quite possible that the position of American commerce might have appreciably Limproved. 56

\section{THE COUNT ROMANZOFF INITIATIVE}

Although discouraged by his apparent lack of diplomatic success, Armstrong tried alternative measures, even if they were long shots. One of his inftiatives was to seek the support and ald of the Russian Forelgn Minister, Count Romanzoff, who was in Paris to arrange with Champagny the detalls of joint Russian and French diplomacy. There had previously been a disposition on the part of the Russians to promote and maintain the rights of commerce generally. Russia was more than likely encouraged by Denmark, Prussia, and the smaller Baltic powers iwho are literally starving under the rigid prosecution of the present anticomercial system." 57 This fact was another reason to believe that the modification of the Continental system was indeed being contemplated. Since Napoleon's allies and those powers which he controlled were balkIng at thelr predicaments, the Emperor could not have been totally deaf to their plight.

Armstrong speculated that Count Romanzoff just might possibly Influence the French Cabinet to mitigate its position with regard to American commerce. Though doubtful, Armstrong flgured that the experiment was at least worth a try, aince Napoleon was away in Spain. 
Armstrong recognized that it would be supported by American complaints, as well as by those of the whole manufacturing interests of France and her dependencies. 58

In November, 1808, William Short had arrived in Paris. He had been appointed American Minister to Russia, although he still awaited Senate confimation. The fact that an American minister would soon be going to St. Petersburg seemed to please Romanzoff, and he promised to replace André Daschoff, the chargé at Washington, with a full minister. 59 The Russian minister told Armstrong that ever since he had come into office, he had been desirous of producing this effect. For in dissolving their comercial connections with Great Britain, it had become necessary to seek some other power as a substitute, and the United States would do nicely. 60

Encouraged, Armstrong sought to use the Count to get the Emperor to alter his position with the United States and return to France's previous position with regard to rights of neutral commerce. Unfortunately, Armstrong's initiative proved hopeless. The Count had already tried approaching the Emperor for the Danes, who wanted compensation for their plundered comerce. ${ }^{61}$ The Emperor's response was to tell the Danes that he would examine the claim, however, he had no intention of making good on 1t. 62

Once more, the prospects for any sort of rellef in the Emperor's system were shattered. On January 2, 1809, Armstrong reported to Madison that no change was to be expected, as he had recelved no encouragement from the Russians. In fact, far from being mollified, the French system was being even more greatly enforced. Armstrong 
confirmed that:

...their anti-neutral system is more rigidly observed;
the embargo on ships of the United States found here (before
the Imperial Decrees were 18sued) 1s continued; every ship of
ours coming into a port of France, or of her allies, is imme-
diately seized and sequestered; cargoes, regularly admitted
to entry by the custom houses, are witheld from their owners;
ships most obviously exceptlons to the operations of the de-
crees, have been recently condemned, and, what in my view of
the subject does not admit aggravation;--the burning of the
ship Brutus on the high seas, so far from being disavowed,
is substantially justified. 63

Armstrong had already predicted this renewed hostility against American commerce when he judged that the fallure of the French peace Initiative with England would only newly irritate the Emperor, resulting In a greater adherence to his decrees. 64 
Notes

\section{Chapter V}

IOn Feb. 21, 1808, Napoleon gave orders to secure the Spanish royal family. On March 19, Charles IV abdicated the throne in favor of his son Ferdinand. The French army entered Madrid, and Napoleon left Paris for Bordeaux and Bayonne on April 2.

2 Armstrong to Madison, March 1, 1808, NA Despatches, Vol. XI. 3 Madison to Armstrong, Feb. 8, 1808, NA Instruct8., VI, $443-447$. ${ }^{4}$ Armstrong to Madison, April 5, 1808, NA Despatches, Vol. XI; Armstrong to Champagny, April 2, 1808, NA Despatches, Vol. XI.

${ }^{5}$ Armstrong to Madison, April 5, 1808, NA Despatches, Vol. XI. 6Adams, IV, 302-303. Gloves, 233-252, asserts that from 1807 to 1814, Napoleon launched a serious drive to win command of the seas, and that the Royal Navy took this drive serlously. The author demonstrates that the number of battleships England was able to put to sea dropped from a high of 113 in 1808 and 1809. Napoleon's number of battleships Increased, numbering 80 as compared to 99 for Britain by the end of the war--a number dangerously close to Britain's. Napoleon was also making use of new harbors as well as those good ones gained through his conquests.

TPerkins, 166, states that Napoleon at first objected to the Embargo because it fell short of war. Napoleon was also initially concerned about the effect of the Embargo on French colonies in the 
West Indies, but he eventually was 11 ttle interested in these colonies. See Armstrong to Madison, April 15, 1808, NA Despatches, Vol. XI.

8 Armstrong to Madison, Apr 11 23, 2808; Armstrong to Madison, Apr11 25, 1808 (postscript), NA Despatches, Vol. XI. The only authentic information received by the state Department relative to the text of the Bayonne Decree is Armstrong to Madison, April 23 and 25, 1808, ASPFR, III, 291. Stockder, 503, states that there was some validtty to the charge that certain American ships which violated the Embargo law were only pretending to be American ance they had evaded the Embargo by using fraudulent British papers and registers.

9 Melvin, 72 .

${ }^{10}$ Armstrong to Madison, June 6, 1808, NA Despatches, Vol. XI. See also Armstrong to Madison, May 16, 1808, NA Despatches, Vol. XI. 11 Adars, IV, 304-305. 12 Madison to Armstrong, May 2, 1808, NA Instructs., VI, 458. ${ }^{13}$ Ibid. 14 Armstrong to Madison, June 25, 2808, NA Despatches, Vol. XI. ${ }^{15}$ Madison to Armstrong, May 2, 1808, NA Instructs., VI, 458. ${ }^{16}$ Ibid.

17 Armstrong had previously sent a note on June 10,1808 to Champagny declining the Emperor's terms for a proposed alliance. Armstrong to Champagny, June 10, 1808, NA Despatches, Vol. XI. See also Armstrong to Madison, June 25, 1808; Armstrong to Champagny, June, 1808, NA Despatches, Vol. XI.

${ }^{18}$ Joseph, Napoleon's brother had assumed the throne of Spain on June 15, 1808. 
${ }^{19}$ Armstrong to Madison, July 7, 1808, with enclosures, MA Despatches, Vol. XI.

${ }^{20}$ Napoleon to Champagny, June 21, 1808, as quoted in Adams, IV, 311.

${ }^{21}$ Armstrong to Madison, July 8, 1808, NA Despatches, Vol. XI. See also Champagny to Armstrong, June 22, 1808, NA Despatches, Vol. XI. 22 Armstrong to Madison, July 8, 1808, NA Despatches, Vol. XI; Champagny to Armstrong, June 22, 1808, NA Despatches, Vol. XI.

${ }^{23}$ In 1806, through Talleyrand, Napoleon had given assurances of his desire to see an amicable settlement of Spanish-American issues, then reversed himself, contrary to his promises, and sided with Spain in affirming that West Florida was indeed Spanish territory and not part of the Loulslana Territory sold to the United States. Talleyrand found himself in a difficult position to extricate himself with his honor intact. ${ }^{24}$ Armstrong to Madison, July 8, 1808, NA Despatches, Vol. XI; Armstrong to Champagny, July 8, 1808, NA Despatches, Vol. XI. 25 Armstrong to Madison, July 8, 1808, NA Despatches, Vo1. XI. 26 Armstrong to Champagny, July 4, 1808, NA Despatches, Vo1. XI. 27 Four American shlps were stopped by French ships-of-war in the high seas and ordered burned by Rear Admiral Baudin. Property from the ships was placed under the jurisdiction of the Imperial Council of Prizes to be judged by it as a case of ordinary capture. Armstrong posed the question as to whether or not the French Government condoned the conduct of Baudin in burning or destroying ships and merchandise of a frlendly power on the high seas. Armstrong to Champagny, July 10, 1808, NA Despatches, Vol. XI. 
${ }^{28}$ Armstrons to Madison, July 26, 1808, NA Despatches, Vol. XI. 29 Armstrong to Jefferson, July 28, 1808, Jefferson Papers LC, Reel 41.

30 Ib1d.

31 Armstrong to Champagny, Aug. 6, 1808, NA Despatches, Vol. II. See also Armstrong to Madison, July 31 and Aug. 18, 1808, NA Despatches, Vol. XI.

32 Armstrong to Madison, July 31, 1808, NA Despatches, Vol. XI. 33 Armstrong to Champagny, Aug - 6, 1808, NA Despatches, Vol. XI. See also Armstrong to Benevent, Aug. 26, 1808, NA Despatches, Vol. XI. 34 Armstrong to Madison, Aug. 28, 1808, NA Despatches, Vol. XI.

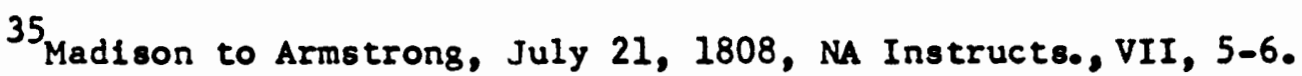
${ }^{36}$ Adams, IV, 313, refers to this decision as a flat refusal to obey his instructions. One must presume that Armstrong had previously protested, but owing to existing circumstances, Madison's instructions were not appropriate or sulted for the situation as assessed by Arm8trong.

37 Armstrong to Madison, Aug. 28, 1808, NA Despatches, Vol. XI. ${ }^{38}$ Ibid. See Armstrong to Benevent, Aug - 26, 1808, NA Despatches, Vol. XI.

${ }^{39}$ Armstrong to Madison, Aug. 30, 1808, James Madison Papers, Manuscript Division, Ilbrary of Congress, Washington, D.C., microfilm copy, Reel 10; hereafter cited as Madison Papers LC, followed by reel. 40 Perkins, 166.

41 Melvin, 71 .

42 Champagny, "Report to the Emperor," Sept. 1, 1808, as quoted in 
Perkins, 166.

${ }^{43}$ Armstrong to Madison, Aug 30,1808 , Madison Papera LC, Reel 10. ${ }^{44}$ Dumas Malone, Jefferson and H1s Time, 5 vols. (New York, 19481974), $v, 616$

$45_{\text {Burt, } 264 .}$

46 Adams, $V, 28$.

47 Armstrong to Madison, Oct. 25, 1808, NA Despatches, Vol. XI. 48 Melvin, 73.

${ }^{49}$ Ibid., 74. The Bordeaux Petition was drawn up by merchants of Bordeaux who were concerned about the adverse effects of Napoleon's decrees on Franco-American trade. It complemented many of Armstrong's arguments.

50 Melvin, 74-75.

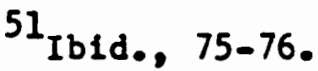

52 Armstrong to Madison (private), Oct. 20, 1808, Madison Papers LC, Reel 10.

53 Melvin, 76.

54 Ibid., 77.

55 Ib1d., 83.

${ }^{56}$ Sear8, 316, credits Armstrong's recommendation as a contribution to the modification of the Continental System.

57 Armstrong to Madison, Dec. 6, 1808, NA Despatches, Vol. XI. ${ }^{58}$ Ibld.

59 Adame, V, 29.

60 Armetrong to Madison, Nov. 24, 1808, ASPFR, III, 299.

6I Armetrong to Madison, Jan. 2, 1809, MA Despatches, Vol. XI. 
62 Writings of Gallatin, II, 490n.

${ }^{63}$ Armstrong to Madison, Jan. 2, 1809, NA Despatches, Vol. XI. 64 Armstrong to Madison, Dec. 14, 1808, NA. Despatches, Vol. XI. Napolion had eent agente to England with proposals for the establishment of peace. The British Cabinet, with little hesitation, rejected the terms as unsatisfactory. 
CHAPTER VI

\section{MOUNTING FRUSTRATIONS}

From the end of 1808, until his return to the United states in the Fall of 1810, Armstrong became increasingly frustrated with his diplomatic position, understanding that the chances of accomplishing his objectives were slight in light of Napoleon's actions and attitudes toward American commerce. As his frustratione increased, so did his temper. He did not fail to express his anger to his superiors in Washington, nor did he fall to offer them very candid assessments of his position as it pertained to Franco-American relations. No doubt such honesty was received with mixed feelings as the Administration reluctantly became aware of the fallure of peaceable coercion in which they had placed 80 much stake.

Armstrong's temper, bad in the winter of 1808-1809, became worse in the epring. ${ }^{1}$ His anger was certainly justified by the French attitude toward the United States, as epitomized in Champagny's instructions to Turreau. The French Minister of Foreign Relations informed Turreau that he should not hesitate to stress the legitimate grievances the Americans hed against England. This approach was certainly not designed to lessen Madison's Irritation. Champagny further remarked to Turreau that:

The Americans would like France to make then commerclal privileges which no nation at present enjoys....But...hitherto it has not seemed proper, in the execution of general measures, to introduce exceptions which would have really destroyed 
their effect. If the rules adopted againat English comerce had not been made common, that commerce would preserve the same resources as before for supporting the war. A system of exception for one people would turn the rule into an injustice toward all others; all would have right to complain of a privilege sranted to the Federal government which themselves would not enjoy. 2

It would have behooved Napoleon to have at least softened the harshness of his commercial policy toward the United states by offering the President some compensation elsewhere, such as Florida. Such a move would have had the effect of concentrating American hostility toward Great Britain, thereby favoring France. In December, 1808, Napoleon could not have retained the hope of controlling the Spanish colonies by force, yet he ordered the American government to leave them alone, as he ordered 1 to adopt the French system of commercial restraint. Thus the President found himself, because of Napoleon's attitude, in an extremely difficult and precarious position, especially as to why he should not go to war with France as well as with England. 3 Turreau': attitude, coupled with the information contained in Armstrong' despatches, should have convinced Jefferson and Madison to belleve sooner than they did that neither favor nor fustice could be expected from Napoleon. This suspicion should have been supported further by many private reports and observations received from France during the winter of 1808-1809. Although American attitudes may have been growing more hostile toward France, subsequent bulletins of the Emperor's successes in Spain were influential with the refusal of Congress to declare a double war. 4

On January 22, 1809, Napoleon returned suddenly to Par1s from Spain, ostensibly for the purpose of preparing for the impending 
clash between France and Austrla. 5 Although Napoleon was able to dipose of Austria, there were many signs of growing discontent among his allies and satellite countries, as well as increasing domestic pressure of commercial and agricultural interests, over the enforcement of the Continental system. 6 sensing that there was a definite need to alter his Continental System, Napoleon decided on the license system, a gystem borrowed from the British, on February $14,18090^{7}$ In 80 doing, he offered, on February 16, to release American vessels from the embargo. This was in the form of a decree issued simultaneously with: the decision in favor of 1icenses. 8 Although evils were inherent In it, Napoleon knew it to be a relatively effective system which would serve simply as a temporary expedient to relieve pressure. 9 Armstrong Informed the Secretary of State about Napoleon's offer to release American vessels. Armstrong, however, percelved that there was no real change in the disposition of efther belligerent toward the United States. Armstrong was skeptical of Napoleon's promise that embargoed American ships in French ports and those of her dependencles would be released, on condition of their direct return to the United states. 10

Proving Armstrong's akepticism justified, a few days after February 16, 1809, Napoleon attached various conditions to the release of the American ships, conditions which Armstrong strongly opposed. To him, these conditions represented open discrimination against the United States, the equivalent to isouing French Ilcenses for American ships to even sail the high seas. 11 The most probable reason Influencing Napoleon to attach conditions was the news from the Unfted 
States of the probable adoption of non-intercourse act affecting trade with England and France. 12

Armstrong's bellef that the.Embargo had falled miserably to accomplish its objectives was confirmed. He foresaw no good reason to continue it in force, and as he was accustomed, bluntly said so to his superiors. It had obviously not produced the desired political effect abroad, and it had produced some effects at home less desirable that they could have wished. The American minister called for throwing open comerce to all but France and England, and to let those who 8 t11l wished to trade with those two countries, desplte the risks, suffer the consequences if need be. 13

Armstrong, as usual, forcefully expressed his disapproval of the conditions being imposed by the Emperor in his decree of February 25, 1809, In addition to the terms atated in Champagny's letter of February 20. Having recelved this letter, Armstrong immediately ordered that the owners and consignees of the American ships being held in French ports, should, after securing bond, proceed to the United States. They should avold touching at any port or place which would expose them to future detention by either belifgerent. Believing that this rule fulfilled all the intentions of the two governments, Armstrong was surprised to learn from the American consul at Marseilles that a new regulation on this subject had been imposed, and that bonds were required by the Imperial custom house which amounted to twice the value of the ship and cargoes. They were conditional for the direct return of the ships to the United States. In lodging his complaints over this requirement, Armstrong referred to it as a "discriminating and unfavorable 
policy with regard to the flag of the United States."14

Thoroughly disgusted with this latest action of the French government, and angered by the difficult position in which both Great Britain and France had placed the United States, Armstrong once more advised the United States to take a firmer stand, this time against both Great Britain and France. Armstrong knew that war was unavoldable. Even Madison ultimately had to accept the same conclusion, though he procrastinated until the United States was seriously divided and England was on the verge of defeating Napoleon, thus being able to direct greater attention to the United states than she would have been able to do if the Administration had accepted Armstrong's advice for war sooner. Although the Administration felt that war against one belligerent, let alone both, was unthinkable, Armstrong belleved that unity of purpose was the most important factor to conelder. He argued that a war with only one of the belligerents would paralyze half of the American effort. He reasoned:

... whereas a war with both, will put into motion every drop of American blood, and will be followed by many other useful consequences, among which I consider as most important, the siving to our people some new views of interest, and some new principles of action; and the turning from a perilous foreign commerce (which cannot be maintained but by a navy and which is, besides, always touching and talnting your politics) into the 1 ess profitable, but more secure and independent channels of useful manufacture.

It is true there may be something appalling in the idea of waging war with the two great champions of the universe, at the same time and ingle handed, and it may even require cond1derable firmness to get over the apprehension arising from the possible union of their forces against 48 , but besides their mutual hatred and discord, our guarantee, on this head, will be found in the obvious circunstance, that the war with France, would but be nominal (a mere war of words and paper) while with England, it would take a character of most seriousness and activity. To illustrate this distinction by an example--As things are going in the Spanish colonies, France can feel no great interest in saving the Floridas, and would (no doubt) 
be more gratified at seeing the British army routed from Canada and Nova Scotia, than mortified at learning that Pensacola, Mobile, and St. Augustine were in our possession. ${ }^{15}$

EMBARGO REPEALED, NON-INTERCOURSE, A NEW ADMINISTRATION

Recognizing that, as a measure of peaceable coercion, the Embargo had clearly failed to force Great Britain and France to rescind their illegal measures, Armstrong urged that it be repealed. After much resistance, the Administration was forced to reach the same conclusion. The repeal of the Embargo Act coincided with the expiration of Jefferson's second term as president. Although the Embargo may have delayed the outbreak of war, Jefferson's most ambitious foreign policy initiative only had the effect of delaying the war until a less favorable time in 1812. ${ }^{16}$ The difficulty was not necessarily in the Embargo's composition or in its general purpose, but in the special reasons Jefferson had for adopting 1t. He overestimated America's coercive power. Designed in part as a means to punish Britain, the Embargo's fallure led directly to the War of 1812, and pointed up the flaws in Jefferson's understanding of the balance of power in Europe. 17

At the end of February, 1809, the Non-Intercourse Act was passed, not because it was popular, but because it contained the repeal of the Embargo. Although not wanting to 80 to war, some Congressmen at least wanted to appear to be making a sacrifice in light of the abuses of national honor, therefore, compromise occurred. The new act contained "scraps" of various plans. ${ }^{18}$ Besides repealing the Embargo laws, this act excluded shipe from French and British porte, and closed American ports to both countries after May 20, 1809. It forbade, under the 
threat of severe penalties, the importation of Britioh or French goods, and it gave the President authority to reopen by proclamation the trade with France or England in case either of these countries should cease to violate neutral rights. 19 In effect the law did three things. It Invited concessions from England and France while continuing pressure on them. It allowed trade with the few remaining neutrals. And thus it gave a backdoor entry to belligerent markets. 20

If the Embargo did not convince Great Britain or France to alter their systems, no one serfously belleved this act would be able to do so either. Although intended to be impartial, the act, unlike the Embargo, actually favored Britain over France. The French had fewer alternatives for export markets or points of shelter for their ships. Champagny complained to Hauterive that this decision was:

...unfavorable to France against which the United States can have no complaint that she has attempted to invade their sovereignty nor to have comitted acts of violence against their coasts and their vessels. 21

The Royal Navy would make sure that relatively few American ohips slipped into enemy ports, whereas the French could hope to intercept only a small proportion of those ships that chose to violate the law by salling to England. David M. Erskine, British minister to the United States, was Indeed pleased about the passage of the Non-Intercourse Act, which he recognized would benefit England. He expressed this viewpoint in a letter to British Forelgn Secretary, George Canning, on February 10, 1809.22

When the final strugsle took place in Congress over the repeal of the Embargo, no small share of the Administration's willingness to 
pasa the repeal was due to their realization that doing so would relleve them of appearing to obey the dictates of the Emperor. No doubt the pessimlotic letters from Armstrong and Turreau's attitude had also convinced them that a favorable alteration in the Emperor's system could not be expected. Turreau recognized the significance of the Embargo repeal, and was irritated to see his influence decline. Men who had given him pledges that the Embargo would be withdrawn only when war against England should be declared, could offer no better excuse for failing to honor their promise than that Napoleon had forfeited his claim to their support. ${ }^{23}$ On March 19, 1809, two weeks after Congress adjourned, Turreau wrote to Champagny from Baltimore:

You will have judged from my last despatches that the Embargo law would be repealed. It has been so, in fact, despite my efforts to maintain it, and notwithstanding the promise of quite a large number of influential Representatives, especially among the senators who had guaranteed to me its continuance t111 the next Congress, and who have voted against their pol1tical conscience. I had informed your Excellency of the disavowed opposition to the continuance of the embargo, and their threats to resiet its execution, terrified Congress to such a degree that the dominant party became divided, and the Feebleness (faiblesse) of Mr. Jefferson sanctioned the last and the most shamefuI act of his Administration..... Isay it with regret, - and perhaps I have said it too late, - I an convinced there is nothing to hope from these people. 24

On March 4, 1809, Madison assumed the office of President and Jeffersor retired to Monticello. Out of office for only two days, Jefferson wrote a friendly letter to Armstrong in Paris, dated March 6, 1809, in which the former president explained the reasons for the repeal of the Embargo. He stated that if the decrees and orders were not revoked before the next meeting of Congrese in May, war would surely follow. Referring to Armstrong's advice to seize the Floridas, Jefferson told Armstrong that they would indeed become America's the first moment that 
any war was forced upon the United States, or when the Floridas were threatened by any other power. ${ }^{25}$ Out of office, Jefferson seems to have reached a point at which he was more willing to accede to the advice which he had previously tried to avold. Although Jefferson and Armstrong were not the closest of friends, their correspondence indicates that they possessed respect for each other.

Like his predecessor, Madison was an advocate of peaceable coercion, and shled away from confrontation and war. Therefore, it is not ourprising that he, too, as president, preferred to avoid Armstrong's advice whenever he called upon the Administration to take a firmer stand in defense of neutral rights or in support of national honor. Like his predecessor, Madison sought alternatives to war to achleve his objectives.

In Armstrong's first set of instructions from the new Secretary of State, Robert Smith, dated March 15, 1809, he was officially Informed of the passage of the Non-Intercourse Act prohibiting commercial trade of the United States with Great Britain and France. Although this measure was not intended as a hostile act, it was, nonetheless, a determination not to merely acquiesce to the edicts of the belligerents. At the same time, it was clear that the Administration had deemed it expedient to repress any desire for use of force to preserve American rights. Nevertheless, when Congress was to meet again on May 4, 1809, had the belligerents still not demonotrated a similar concillatory splrit other measures would doubtless be adopted as the honor of the United States might require. Secretary Smith informed Armstrong that the latter was authorized to tate that if the edicts of either of the 
belligerents were entirely revoked, or even modifled so as not to infract American neutral righte, it was the opintion of the President that Congress would, at the ensuing special sesston, authorize acts of hostility against the other belligerent. Armstrong was instructed to refer to this opinion in conversation, but not to state it in writing because of the peculfar delfcacy of its character, unless he recefved satisfactory assurances that its intended purpose would be fully accomplished. 26

In urging revocation of the French decrees Armstrong was to stress the equitableness of American claims, and was to be guided by the arguments that: (1) they violated maritime rights, which the United States, as a neutral power, claimed under the law of nations; (2) they violated American rights under the existing Treaty of 1800; and (3) they created a pretext for the British continuing their orders in Council in force, extensively affecting the commercial relations of the United States. 27

Meanwhile, the Emperor had left Paris on April 13, 1809, for the Danube to fight Austria once again. On April 19, he crossed the Inn and began the war. ${ }^{28}$ During the next three months, his hands were full. The time was not ideally suited for diplomatic business pertaining to American affairs as Armstrong had been ordered, especially as Napoleon had left Paris a few days after Smith's instructions vere recelved in Paris. However, in acknowledging recelpt of these instructions, Armstrong indicated that he would make another attempt to obtain the repeal or modification of the Emperor' decrees. Armstrong recognized, however, that there was little hope of success, especially since the 
Emperor was preoccupled with military mattere. Armstrong correctly estimated that this latest military adventure would engage the Emperor for two or three months. 29

Obeying his instructions, though, Armstrong went to see Champagny, only to discover that the latter had jolned the Emperor in Germany. To pureue him there was not permissable, as the Emperor did not see ministers of foreign countrles during a campaign. Armstrong, therefore, wrote a letter to Champagny, enclosing a copy of the Non-Intercourse Act, and a general assurance of the act's pacific character. 30 He also Informed Champagny that:

....the undersigned is Instructed to add, that any interpretation of the Imperial decrees of the 21 Nov. 1806, and 17 Dec. 1807 which shall have the effect of leaving unimpaired the maritime rights of the Union, will be instantaneously followed by a revocation of the present act, and a re-establishment of the ordinary comercial intercourse between the two countries. 31

Armstrong debated whether he should wait until he could personally meet with Champagny before informing him of the other part of Armstrong's instructions. He soon decided that he would relate that portion of the Secretary's message to Champagny in witing after all. The letter to Champagny stated that if France were to exempt American ships from future vexation and capture, and if Great Britain would not do the same, then the President would advise an immediate rupture with the latter. 32 Just how the Emperor would view this proposition was uncertain. Armstrong speculated that, since the proposition made to England was exactly the same as the one made to France, the Emperor would probably postpone his decision until he saw what England was likely to do. If, for any reacon, England did modify her policy according to American 
whes, the Emperor would then probably follow suit in order to preserve some degree of consistency between his practices and h1s preaching, and to prevent England from having the benefit of American arms and comerce at once. If, on the other hand, England continued in her tenacious manner toward the United States, Napoleon would no doubt persevere in h18. 33 Champagny, from Augsburg, merely acknowledged recelpt of Amrstrong's letter of Apr1l 28, 1809, containing notice of the passage of the Non-Intercourse Act, without making any further couments or observations. ${ }^{34}$ In fact, mere acknowledgement was all that Armstrong had received from the French Minister in response to any correspondence since Champagny had left Paris to Join the Emperor. ${ }^{35}$ wishing to recelve more definitive anowers from Champagny, Armstrong, sincerely desirous of returning to the United States, tried to use this as a means of prompting a greater response from the French government. The General Informed Champagny that he wished to return to the United States for a few months in order to deal with private business matters. Since the American ship, Mentor, was nearby at L'orient, he wished to take advantage of it. He therefore requested passports for himself and his family. In preparing to depart, Armstrong decided to leave Mr. Ridgway, Consul for the port and district of Antwerp, in charge of the legation at Paris until his return. Armstrong told Champagny how much he wished to see friendship reotored between the two countries. He stated: "The satisfaction that such an arrangement would give to my Government would be second only to the regret it would feel, were the subsisting differences either to continue or to increase." 36

Armstrong informed Champagny that he did not want to return to the 
United states without first receiving the consent of the Bmperor. It was entirely with the viev of obtaining that consent that his applicat10n: for passports was made in writing and forwarded to the Emperor'e headquarters. 37 Although serlous about returning to the United states, Armstrong nonetheless also used this as a ploy designed to prompt a positive response from the Emperor.

\section{NEWS FROM ENGLAND}

Compounding Armstrong's already difficult diplomatic position was his leck of officlal correspondence from Pinkney, American minister in London. An examination of Armstrong's diplomatic correspondence clearly reveals that he was irritated by Pinkney's fallure to keep him posted as to what was transpiring in Great Britain that might have a direct effect on Armotrong's position with the French government. Since Pinkney had instructions simflar to Armstrong's, he was to comnunicate to Armstrong any British advances made toward the adjustment of AngloAmerican differences. 38 Armstrong became all the more anxious when journal reports started to appear in France which suggested that the United States and Great Britain had settled several points of controversy. The British government supposedly rescinded certain parts of Its Orders in Council that had Imposed a tribute on Anerican comoerce. No doubt Armstrong tried to exploit these rumors to his advantage, while playlng coy by stating that any such rumors were not to be credited as official oince he had not heard from the American minister in London. The possibility of an adjustment in London allowed Armstrong to press the French goverment for an adjustment of Franco-American 
differences on equitable terms repecting American rights. 39

St111 not having heard anything officlal, Armstrong recelved accounts from England which Indicated that the British Orders in Council had indeed been revoked, and that the United States had also revoked.1ts Non-Intercourse Act. Recognizing that these revelations were at varlance with his letter to Champagny of May 26, 1809, Armstrong was compelled to protect his official position, and honestly disavowed having any official knowledge of arrangements which may have transpired; he reiterated once more that Pinkney 8 till had not informed him of any changes. 40

In the meantime, French abuses continued and Armstrong directed his energies toward protesting them. On June 4, 1809, Armstrong wrote a letter of protest to Champagny concerning the American ship, Jefferson, which had fallen into the hands of French ships of war on April 25. After the ship had been visited and the crew removed, the vessel was burned. As Armstrong emphatically pointed out, this was the seventh instance in which such an outrage had been committed on American vessels by the Emperor's ships of war--outrages which had no parallel In the history of modern abuses. Armstrong demonstrated his digust and extreme concern to Champagny: "It 18 accordingly within the letter of my instructions to say, that unless full and imediate reparation be made, the United States cannot but regard this new outrage as one of premeditated host111ty."41

Not having heard anything significant from the French government, Armstrong, In light of the above-mentioned incident, wrote to Secretary Smith on June 6, 1809 that such a delay under the circumstances might 
very well be interpreted as a refusal to the American proposition, and as such, a justification for a rupture between the two countries. Armstrong ascertained, however, that the Battle of Essling had temporarily placed the Emperor in a most critical position, comanding the Emperor's attention. Armstrong recognized that Napoleon was probably not fighting for glory or empire at that moment, but more likely for existence itself. Armstrong offered three possible explanations or outcomes. (I)That nothing of a nature merely political had yet been submitted to the Emperor, and that nothing of that character would be submitted until the fate of the campaign had been decided. (2)That if defeated and driven from Germany, Napoleon's policy, with respect to the United States and others, would necessarily undergo great changes. (3) If successful, the consideration that the United States had not chosen that moment to put themselves on the list of his enemies might render a reconciliation easier. Whether or not these considerations justified deferring until the next session of Congress, the adoption of any new measure with regard to France was a question, according to Armstrong, that Congress itself had to decide. 42

Having walted for month for official confirmation of changes in Great Britain's relationship to the United States, Armstrong finally was informed by Pinkney of the British Order in Council of April 26, 1809, and of the Erskine Agreement, reached between that minister and the United States. The consequence of that agreement had been a proclamation by President Madison on April 19, 1809, which renewed American trade with Great Britain on June 10 , the date the British Orders in Council were to be withdrawn. 43 
The instructions from Secretary Smith, dated April 21, 1809, included printed copies of the correspondence between Smith and Erakine over the Chesapeake affair, the revocation of the British Orders in Counc1l, the British proposal to send a special envoy to conclude a treaty, and a copy of the President's proclamation. Armstrong was urged to seek the earliest opportunity to assure the French government that there was not, in this adjustment with Great Britain, nor would there be in the proposed treaty, anything to any degree inconsistent with the friendiy adjustment of American differences with France. On the contrary, there was a reasonable expectation that the revocation of the British orders in Council would remove every motive for the continuance of the 11 legal parto of the French decrees. 44 A week later, bolstered by his apparent diplomatic victory, reflecting the Administration's newly-acquired confidence, the secretary of state wrote that, as no pretext remalned for the perseverence of the French government in its decrees, Armstrong was to:

...let it be understood that their immediate revocation is confidently expected, and the more 80 , as the President indulges the persuasion that the Emperor 1s sincerely disposed to reestablish the suspended relations between the two countries. 45

If the Emperor was disposed to withdraw his decrees, he was, it was presumed, aware of the propriety of doing it so as to take effect immediately. In this case, Armetrong was authorized to assure the French goverment that the President would not fail to isaue his proclamation in accordance with the eleventh section of the act of Congress, as soon as the revocation of the decrees was known to him. 46 This set of instructions did not reach Armstrong unt1l the night 
of June 11. Just when it appeared the American minister had acquired additional diplomatic leverage, this advantage vas erased. He became Increasingly aware that the Erokine Agreement was apparently disavowed by the British Government. Armstrong was placed in a difficult position, seeing imediately that the French would be able to use the disavowal to their advantage. Armotrong knew that the French would say that only when Great Britain had actually sanctioned the Erskine Agreement would the appeal to the Emperor be made. To escape the embarrassment that such an answer might have produced, Armstrong decided to barely mention the arrangement, and referred to it as a new proof that there was no disposition on the part of the American government to enter into engagements which would not preserve inviolate all the rights of American maritime independence. ${ }^{47}$ In his note to Champagny of June 12, 1809, Armstrong quickly moved to lessen the effects of a possible disavowal of the Erskine Agreement, by stating that, although the British king might indeed eventually refuse to sanction the arrangement, he could neither combat the justness, nor diminish the force of the conclusion. 48

Soon thereafter, Armstrong received official word from Pinkney confirming his suspicions as to the reason for that minister's si= lence. 49 In a letter dated June 3, 1809, Pinkney enclosed coples of British newspaper which showed exactly what had transpired in Great Bxitain as related to American affairs, and what was likely to happen. Plnkney expressed his apprehension, as he did not know how news of the disavowal of the Erakine Agreement would be received in the United States. Pinkney further informed Armstrong of the latest Order in 
Council, which was undoubtedly a measure to conclliate the United States, although he, Pinkney, had not chosen to be a party to it. It was to be considered a Britieh measure, binding the United states to nothing, and looking for no step to be taken on the part of America. Finally, Armstrong was told that a vessel had sailed to America with Erskine's recall. His successor, Francis Jackson, would proceed on his mission in two or three weeks. 50 Madison and Smith's diplomatic victory had been short-lived, and Armstrong had no doubts as to the consequences for h1s postion with Napoleon and Champagny.

\section{INTERVIEWS WITH HAUTERIVE}

Having received no correspondence from Champagny in many weeks, other than brief acknowledgements of his letters, Armstrong reasoned that the Emperor had been too preoccupied with military matters to contemplate American affairs. However, Napoleon had been paying far more attention to American affairs than the General could have known. 51 Never in his career had the Emperor been busier than when Armstrong had written his note to Champagny of April 29, 1809, but it caught Napoleon's attention at once. He had fought battle after battle, and on May 10, 1809, he entered Vienna and took up headquarters at schönbrunn, the favorite palace of the Austrian emperor. He was still in an extremely precarious military position when he learned, through despatches from Paris, that the United States, on March 1, had repealed the Embargo Act, and that the British Orders in Council of November, 1807, had been withdrawn on April 26, 1809, leaving only a blockade of Holland, France, and Italy. The effect of these two events was greatly magni- 
fied because of their simultaneous nature. 52

Napoleon, at first, saw no reason to alter his direction. After reading Armatrong's letter, he dictated a reply that was almost the same as the Milan Decree 1tself. Shipe were floating colonies of a nation. When American vessels were violated by British searches and taxes, they could only be considered as denationalized and, therefore, subject to selzure. 53 Napoleon sent these remarks to Champagny, and four days later, on May 22, 1809, Napoleon fought the Battle of Essing, and sustained a $108 s$ of 15,000-20,000 men--a serious setback which temporarily at least, opened the Emperor's mind to a possible reconsideration of his position regarding the United States. 54 On May 26, 1809, Champagny made a report to the Emperor about American affairs. After recalling the history of the various orders, decrees, blockades, embargoes, and non-intercourse measures, Champagny urged the Emperor to recognize the value of American trade to a country impoverished by the British blockade. He stated as candidly as was possible to the Emperor:

The fact cannot be disguised; the interruption of neutral commerce which has done much harm to England has been also a cause of 1088 to France. The staple products of our territory have ceased to be sold. Those that were formerly exported are lost or are tored away, leaving impoverished both the owner who produced them and the dealer who put them on the market. One of our chief sources of prosperity is dried up. Our interest therefore leads us toward America, whose commerce would bring us either materials of prime necessity for our manufactures, or produce the use of which has become almost fo
necessity, and which we vould rather not owe to our enemies.

Champagny advised Napoleon to cease punishing America. He advised Hauterive; the acting Minister of Foreign Relations at Paris, to discuss with General Armatrong the details for an arrangement between 
the two countries. This move was supported by the argument that England had made advances to America and, in April, had revoked her Orders in Council of November, 1807. This move was further supported when news of the Erskine Agreement settling the commercial dispute between Great Britain and the United States reached the Emperor. 56 Consequently, Napoleon drew up the draft for a new decree, which proclaimed that the United States, by its firm resiotance, had brought about the revocation of the British Orders of 1807. The neror was, therefore, exempting the United States from the Milan Decree and leaving only the Berlin Decree (a blockade of the British Isles) to offset England's modified blockade of French-occupied Europe. 57 On June 13, 1809, Champagny forwarded instructions to Hauterive, directing him to begin negotiations with Armstrong. 58 Consiotent with the train of American fortune, knowledge of the disavowal of the Erskine Agreement reached the Emperor at about the same time that Hauterive's instructions were drawn up. Although allowed to continue his talks, Hauterive was informed that the extreme uncertainty of the situation prevented a decision. 59

In writing to Smith on June 30,1809 , Armstrong was at last able to report that he had received, since June 12, two notes from Champagny, one of June 7, and the other of June 13. With the latter note, Hauterive also delivered a verbal message, stating that he had been instructed to acquaint himself with American business generally, to discuss with Armstrong the subjects of his late notes, and to report from time to time to the Emperor. 60

Although Hauterive requested an interview with Armstrong, the 
American minister was confined to bed for two weeks, and it was not unt1l June 30 that he met with Hauterive in Armstrong's apartment. The Counsellor apologized for Champagny' allence, from May 12 until June 7, assuring Armstrong that the Emperor's occupations between those dates had prevented him from attending to anything foreign or political. Hauterive then referred to the measures about which Armstrong had so often complained. He declared that, as they had been forced upon the Emperor by the abuse of Great Britaln, so they would be immediately renounced by him, on evidence that Great Britain had adopted a system more 11 beral and just. 61

Hauterive then inquired of Armstrong what, after all the recent activity between the United States and Great Britain, was the actual standing of the United States with that country, and what were the modifications of the decrees that Armstrong desired. Armstrong told Hauterive what he had already written to Champagny. With the exception of a single letter juet recelved from Pinkney, Armstrong could honestly state that that was all he knew of what had transpired between Great Britain and the United States. Pinkney's letter clearly established that, as late as June 3, nothing had been done in England of a character that authorized or required Pinkney's participation, and that the only act mentioned by Pinkney at all, was that of the British Council of April 26, 1809. As to Hauterive's second question, Armstrong reminded him that the demands of the United States government had long since been before the Emperor in the form of the Non-Intercourse Act, and in Armstrong's diplomatic correspondence. Somewhat sarcastically, Armstrong atated that if there'were anything difficult to understand in 
either, Armstrong would be pleased to explain it. The difficulty, replied Hauterive, was in finding what sort of modification of the decrees would satisfy Armstrong as well as the pmeror. He posed the questions: Should they be made municipal only, and how far should they go? Should they forbid the entry of a ship coming from England? Should they forbid the entry of a ship which had submitted to a British visit? Armstrong replied:

...any exercise of authority within their own ports, in opening or shutting these to neutral conmerce would be an act against which we could not reasonably object; that between the two cases he had stated, there was some distinction; that to exclude a ship because she had traded with England, would be to punish her for her own act--but to exclude her because she had been visited--would be to punish her because her force was inferior to that of the visiting vessel. After all, it was a question for them, rather than for us to decide, whether this distinction was or was not of sufficient clearness and magnitude, to make any change in their general policy. 62

In closing the conversation with Armstrong, Hauterive spoke of the advantages to both parties that would result from a better understand1ng. He strongly and repeatedly declared the, general good will of the Emperor toward the people and government of the United States. 63 Armstrong, of course, had heard those same affections expressed numerous times.

In assessing this interview with Hauterive, Armstrong, although cautious, was nevertheless somewhat encouraged. He recognized from the temper and character of this interview that an important change in the Emperor's attitude toward the United states had taken place, although Armstrong was unaware of the order which Napoleon had issued earlier similar to the wording in the Milan Decree. If Armstrong's impressions were correct, that change was the result of pressures which had for some 
time been trying to influence the Emperor, then there could be no doubt about its durability; it would at least last long enough to produce the experiment which Hauterive hinted at in his closing remarks. If, however, this change was meant only to tranquilize the United States for the moment and to take 1 ts ultimate form from the fortunes of the military campaign, then less was to be expected from it. Armstrong's suggestion to the Secretary of State was, remarkably, that in any case, the event warranted a little more patience on the part of the United states. 64

In subsequent conversations with Hauterive, he implled that, in the present state of Spain, the Emperor might be willing to give the Unted states advantages in the comerce of its colonies. Armstrong reported that Hauterive repeated the 1dea several times, and although he felt Hauterive probably expected some sort of answer, Armstrong belleved that the ground was "thorny," and he avoided dealing with such a probing question, especially one that had long interested the United States. 65

Although Armstrong had expressed a certain amount of optimism over the interviews with Hauterive, he was, nevertheless, a realist. He had negotiated with Napoleon far too long to simply swallow any balt which he might dangle. Belfeving that the French government would convey its answer fairlysoon, Armstrong prepared for a possible negative response. Anticipating the possibility of a rupture, Armstrong suggested to the Secretary of State that some competent individual ought to be in Parle to take charge of American business, just in case it would be proper for Armstrong to leave, without having 
to take with him all traces of the legation. Quite matter of factly, Armstrong Informed Smith that qualifled ruptures occurred quite of ten, and they were no doubt better than more absolute ones; they left the two nations both having made displays of disagreement, but were still adequate for leading to reconciliation. 66

As Armstrong had learned from experience in dealing with Napoleon, military victories would have an effect on America's relations with the Emperor, to the disadvantage of the United States. On July 6, 1809, Napoleon fought the Battle of Wagram, and on July 12, Austria was forced into submission. The Battle of Wagram, In Napoleon' o way of thinking, placed him in a much stronger pooltion, and made him less inclined to tolerate American resistance to his Continental System. This victory, following shortly the knowledge of the British government's repudiation of the Erskine Agreement, coupled with Napoleon's discovery from a decree of the King of Holland that the Non-Intercourse Act seemed to discriminate against France in favor of the rest of the Continent, compelled him to order the Hauterive negotiations stopped. 67

Armstrong instinctively knew that, for better or for worse, the state created by Napoleon's victory over Austria furnished an opportune moment for discovering the sentiments of the Emperor with regard to American commerce. Armstrong, therefore, sought another Interview with Hauterive. No doubt Armetrong appreclated Hauterlve's frankness, though he probably was not permitted to relate that a change had taken place in the Bmperor's views and in particular that decree which would have been a positive step towards accommodation, prepared by Napoleon's orders as a substitute for those of Berlin and Milan had been laid 
aside. Armstrong related that Hauterive stated that the Emperor:

...will not recede from his present system, until he be asaured, what is your actual standing with England? with. what temper your government has received the modifled order of the Britioh council and the rejection of the arrangement entered Into at Washington ? and above all, whether your views and feelings, with regard to the Britioh doctrines of search and blockade, have euffered any change $3^{68}$

Armstrong had absolutely no doubts as to Napoleon's intentions. If there had been any doubte, they were done away with in that: (1)captures of American vessels by French cruisers continued to be made on the coasts of France, Holland, Italy, and Naples; (2)American cotton, imported through whatever channel, and all cargoes brought by American vessels into the ports of Holland, were excluded by name from the markets of France; (3)American commerce with Holland was subject to a great deal of embarrassment; and (4) in the ports of Naples and Spain, Amerlcan ships and cargoes were, as in France 1tself, actually sequestered. The renewed vigor of French actions against American comerce gave Armstrong serlous doubts as to whether his letter would even make it to America. 69

Writing two days later, Armstrong further assessed the intentions of the Emperor. He ascertained that when Hauterive's answers in a conversation with Armstrong were translated Into plain English, they meant that unless the United States resisted the British doctrines of search and blockade, America was not to expect any relaxation on the part of the Emperor. The Emperor did promise--for what it was worth-that until he knew the President's intentions on these points, he would take no step to make matters worse between the two countries than they already rere. Armstrong put little stock in these promises. 
The recent change in the Emperor's language in regard to American comerce was a change in language only. Circumstances prescribed it for the moment, but when those came to an end, Napoleon came out with the intent of adhering to his old offensive system, qualified only by a promise of changing conditions to which he knew the United States could not, or would not, consent. It was probable, Armstrong stated, that if pressed on this matter, attempts would be made to cover up the real motives, by suggesting doubts about the present American standing with Great Britain, and offering as evidence for these, Canning's letter of instructions to Mr. Erskine. 70

\section{SECRET VIENNA DECREE}

Armstrong's persistent lack of confidence in the Emperor's promises was certainly justified. Quick to yield before evident disaster, Napoleon was just as quick to exhaust the fruits of an evident victory and the advantage he had obtained over the United States was just as decided, if not as extensive, as that which he had gained over Austria. The United States would pay for her deflance by the usual means of seizing her cormerce. ${ }^{71}$

This can be best 1llustrated in the case of an American vessel loaded with a cargo of colonial produce which had arrived at san Sebastian on May 20 after the Non-Intercourse Act had opened trade to Spanish ports. On June 7, 1809, while the Emperor was still hesitating, possibly leaning toward concession with the United States, Decrès asked the Emperor what should be done about this and other such ships. This was a particulariy difflcult case. The French decree had denationalized 
every vessel that had gone to England, wished to go there, been visited by an English cruiser, violeted the laws of the United States, or had been suspected of fraud. The echooner in question, however, was not under suspicion of fraud; she had not been to England, nor had she ever thought of going there; she had not been stopped by a British cruiser; she was in a Spanish port, nominally outside French jurisdiction, and she was authorized to go there by United States law. ${ }^{72}$

Decrès' letter reached Vienna about June 13, 1809. The subject was referred to the Minister of Finance, but no decision appears to have been reached until August. Maret, the Secretary of State in personal attendance to the Emperor gave Champagny, on April 4, the draft of a new decree. Although this decree was never published, it offers a clue to most of the Emperor's detalled movements for the following year. ${ }^{73}$ In consideration of the American Congress's act of March 1, 1809, forbidding entry of all French vessels into 1 ts ports under penalty of confiscation of both ships and cargoes, Napoleon had, on the report of the Minister of Finance, decreed that:

Art. 1. The American schooner loaded with colonial produce and entered at San Sebastian the 20 th May, 1809, will be seized and confiscated.

Art. 2. The Merchandise composing the cargo of the vessel will be conveyed to Bayonne, there to be sold, and the produce of the sale paid Into the caisse de l'amortissement (sinking fund).

Art. 3. Every American ship which shall enter the ports of France, Spain, or Italy will be equally seized and confiscated, as long as the same measure shall continue to be executed in regard to French vessels in the harbors of the United states. 74 
Chapter VI

${ }^{1}$ Adams, $v, 31$.

${ }^{2}$ Champagny to Turreau, Dec. 10, 1808, as quoted in Adams, $V$, 31-32.

${ }^{3}$ Adams, v, 32 .

4Ibid., 32-33. Perkine, 68, states that, instead of encouraging America's European trade which would have benefitted Napoleon directly and perhaps even Involved the United States in war with Britain sooner, from 1807 omward he did everything possible to restrict it.

5 Armstrong to Madison, Feb. 16, 1809, NA Despatches, Vol. XI. Gelvin, 86.

7

7 Ibid.

8 Ibid., 101.

9. Ibid., 87-88, 91.

10 Armstrong to Madison, Feb. 16, 1809, iNA Despatches, Vol. XI. Approximately 20 American ships were involved, not counting those in Holland.

11 Armstrong to Madison, Feb. 21, 1809, M Despatches, Vol. XI; Armstrong to W1lliam Lee [n.d.], enclosed in Armstrong to the Secretary of State, March 22, 1809, M Deepatchee, Vol. XI; Armstrons to Champagny [n.d.], enclosed in Armetrong to the Secretary of state, Apr11 10, 1809, NA Deapatches, Vol. XI. 
12Melvin, 101. See also Armstrong to Madison (private), March 30, 1809, Madison Papero IC, Reel 11.. Armstrong to Madison, March 26, 1809, NA Despatches, Vol. XI.

${ }^{13}$ Armstrong to Madison, Feb. 16, 1809, NA Despatches, Vol XI. 14 Armstrong to Champagny, [n.d.], enclosed in Armstrong to the Secretary of State, April 10, 1809, NA Despatches, Vol. XI. In his despatch to the Secretary of State of March 22, Armstrong referred to this French action as "mere trick" to get from the owners of the embargoed ships bonuses that were double the value of the ships. Armstrong to the Secretary of State, March 22, 1809, NA Despatches, Vo1. XI.

15 Armbtrong to the Secretary of State, March 22, 1809, NA Despatches, Vol. XI.

16 Perkins, 182. On page 174, Perkins states that the Embargo had the unfortunate consequence of providing an excuse for Ineffective military preparations which had eerious consequences when war finaliy came in 1812.

17 Kaplan, "Jefferson, the Napoleontc Wara,...," 205.

18 Perkine, 231.

19. Arnals, 10th Cong., 2nd sess., pp. 1824-1830.

20 DeConde, History, 96.

${ }^{21}$ Champagny to Hauterive, June 13, 1809, as quoted in Perkins, 232.

22

Erakine to Canning, Feb. 10, 1809, as cited in Adams, IV, 445. 23 Adams, V, 33-34.

${ }^{24}$ Turreau to Champagny, March 19, 1809, as quoted in Adams, V, 
33-34.

25 Jefferson to Armstrons, March 6, 1809, Jeffereon Papers LC, Reel 43. For Armetrong's reply, see Armstrong to Jeffercon, June 11, 1809, 1b1d. Although they disagreed on policy at times, both men seemed to have had a mutual reapect for each other. This was far truer with Jefferson than it was with Madison.

${ }^{26}$ Smith to Armstrong, March 15, 1807, NA Instructs., VII, 33-34. Although Robert Smith algned his name to diplomatic instructions, the actual texts were oftentimes written or re-written by Madison.

${ }^{27}$ Smith to Armetrong, March 15, 1807, NA Instructs., vII, 33-34. ${ }^{28}$ Armetrong to the secretary of State, April 14, 1809, NA Despatches, Vol. XI.

29 Armetrong to Smith, April 27, 1809, NA Despatches, Vo1. XI. ${ }^{30}$ Armstrong to Smith, May 3, 1809, with enclosures, NA Despatches, Vol. XI.

31 Armstrong to Champagny, April 29, 1809, NA Despatches, Vol. XI. 32 Armetrong to Smith, May 3, 1809; Armstrong to Champagny, May 2, 1809, NA Despatches, Vo1. XI.

33 Armstrong to Smith, May 3, 1809, NA Despatches, Vol. XI. 34 Ib1d.; Champagny to Armstrong, May 4, 1809, NA Despatches, Vo1. XI.

${ }^{35}$ Armstrong to Smith, May 26, 1809; Champagny to Armstrong, May 9, 1809; Chempagny to Armetrong, May 17, 1809; Armetrong to Champagny, May 19, 1809, NA Despatches, Vol. XI.

${ }^{36}$ Armatrong to Chempagny, May 4, 1809, MA Despatches, Vol. XI. ${ }^{37}$ Armetrong to Champagny, May 19, 1809, MA Despatches, Vol. XI. 
${ }^{38}$ Armstrong to Smith, May 3, 1809, NA Despatches, Vol. XI. See 2180 Armetrong to Smith, May 26, 1809, NA Despatches, Vol. XI. ${ }^{39}$ Armetrong to Champagny, May 26, 1809; Armstrong to Smith, May 26, 1809, NA Despatches, Vol. XI. Erskine, belleving that the forms of American forelgn policy might shift and become favorable to England, suggested to British Forelgn Minister Canning that Canning sacrifice the Orders in Council in order to win American goodwill. Canning accepted the suggestion and Erskine was Instructed to negotlate a settlement, and to explore the possibility of a new commercial treaty. On April 26, a new Order in Council appeared, which seemed to abandon the whole ground taken in the order of Nov., 1807, and to return within the principles of international law. The new decree declared that the old orders were revoked and annulled, except so far as thelr objects were to be retained by a general blockade of all ports and places under the government of France. The blockade was to extend northward as far as the Ems and was to include on the south the ports of northern Italy. The new blockade was not even claimed to be effective. No squadrons were to enforce 1ts provisions by their actual presence before the blockaded ports. In that respect, the order of April 26, 2809, was as 11legal as that of Nov..11, 1807, but the new arrangement opened to neutral comerce all ports not actually ports of France, even though the British flag would be excluded from them. Adams, V, 63, ASPFR, III, 241.

${ }^{40}$ Armstrong to Champagny, June 5, 1809, NA Despatches, Vol. XI. In a private letter to Madison of June 5, 1809, Armstrong Informed the President of the difficulty he was having since he had not been kept 
abreast of developments in England. Having received journals which Indicated an adjustment had been made, he wrote:

I am still this moment... owithout a single syllable either by verbal messages or by writing... a fact the more extraordinary as conveyances have not been wanting and as M.P. himself acknowledged the necessity of communicating with me.

Armstrong to Madison, June 5, 1809, Madison Papers LC, Reel 11.

${ }^{41}$ Armstrong to Champagny, June 4, 1809, NA Despatches, Vol. XI.

42 Armstrong to Smith, June 6, 1809, 1bid.

43 For text of Madison's proclamation, see Richardson, I, 457.

${ }^{44}$ Smith to Armetrong, April 21, 1809, NA Instructs., VII, 40.

${ }^{45}$ Smith to Armstrong, Apri1 17, 1809, NA Instructs., VII, 41-43. ${ }^{46}$ Ibid., 41.

47 Armstrong to Smith, June 30, 1809, NA Despatches, Vol. XI.

${ }^{48}$ Armstrong to Champagny, June 12, 1809, NA Despatches, Vol. XI.

${ }^{49}$ Armstrong to Madison, July 2, 1809, NA Despatches, Vol. XI.

50 PInkney to Armstrong, June 3, 1809, NA Despatches, Vol. XI.

$5 I_{\text {Brant, James Madison, }} v, 79$.

52 Adams, v, 136.

53 Brant, James Madison, V, 79-80.

${ }^{54}$ Adams, v, 137-138.

${ }^{55}$ Champagny to Napoleon, May 26, 1809, as quoted in Adams, V, 138.

${ }^{56}$ Adams, V, 138-140.

57 Brant, James Madison, v, 80 .

58 Adams, V, 140.

59 Ibid., V, 140-141; Brant, James Madison, v, 80. See also Mel-. vin, 102-104. 
${ }^{60}$ Armstrong to Smith, June 30, 1809, N Despatches, Vol. XI. 61 Ibid.

62 Ibid.

63 Ibid.

64 Ibid.

${ }^{65}$ Armstrong to Smith (private), July 3, 1809; NA Despatches, Vol. XI.

${ }^{66}$ Armstrong to Smith, Ju1y 3, 1809, NA Despatches, Vol. XI. 67 Melvin, 104 .

${ }^{68}$ Armstrong to Smith, July 22, 1809, NA Despatches, Vol. XI. 69 Ibid.

70 Armstrong to Smith, July 24, 1809, NA Despatches, Vol. XI. 71 Adame, $V, 142$.

72 Ibid., $142-143$

73 Ib1d., 143.

${ }^{74}$ Imperial Decree, as quoted in Adams, V, 143-144. 
CHAPTER VII

DIPLOMATIC GAMBLES

JOURNEY TO HOLLAND

Napoleon, while giving the appearance he intended to alter his system, had only reverted to his old pollcies toward American commerce, and pursued them with a renewed vigor that made the American position increasingly desperate. Almost at his wits' end, Armstrong sought any means that would offer hope to relleve the status of American commerce. Clearly demonstrating his knowledge and awareness of European events and personalities, Armstrong devised a plan that would hopefully enlist the support of the Emperor's own brother in seeking the relaxation of Napoleon's decrees. In a bold diplomatic gamble, Armstrong decided to proceed to Holland and confer with Louls, the king of that country.

Holland was nominally independent, and its trade was an object of interest. While England shaped her policy to favor the 11censed or smuggled trade with Dutch ports, the United States risked relations with England and France by treating Holland as an independent neutral. The nominal independence of Holland was due only to the circumstances which had made Louis her king, as Joseph had been made king of Spain. Of all Napoleon's brothers, Louls was the one who offended the Emperor the most. From the very moment he went to Holland, Loufs assumed the position of an Independent monarch, and devoted himself to winning the popularity of his subjects. He did not execute the Berlin Decree until 
Napoleon actually threatened war; he connived to evade it and he issued licenses and adnitted cargoes just as he pleased. He did these things with such conscious disregard of the Emperor's wishes, that Napoleon became angry. ${ }^{1}$ Obviously aware of the independent role that Louls was pursulng, knowing that the old system was about to be rigorously enforced against the United States, ${ }^{2}$ and having been advised by several commercial houses in that country that his personal application to the King fust might produce some useful effect, Armstrong decided to set out for Holland to pursue this avenue. ${ }^{3}$

On August 15, 1809, Armstrong arrived in Amsterdam. On August 18, during an Interview with the Dutch Minister of Forelgn Relations, Armstrong firmly remonstrated against the frequent and lawless depredations of French cruisers along the coasts of Holland, and particularly againet French selizures of American vessels within the bays and harbors of the king of Holland. In reply, the Dutch Foreign Minister informed Armstrong that the French government had established the doctrine of "common soverelgnty" between allied nations in each other's bays and harbors. It was a doctrine, however, that the Dutch Forelgn Minister could not subscribe to in terme of 1 ts reasonableness and authority. The Minister further Informed Armstrong that the KIng, after returning to Amsterdam and being informed that Armstrong was in the city, would probably wish to see him. In that case, Armstrong was urged to bring up the subject to the King personally. 4

On Auguet 19, having dined with the Foreign Minister, Armetrong received a note informing him that the king would see him at 7:00 p.m. that evening. Armstrong was admitted into the King's private apartment 
and found him alone, except for a chamberlain. Armotrong reported that a long and free conversation ensued. The King expressed his disapproval of the commercial policies of the Continental system, calling them injustices, and cited his efforts, along with other nations, to oppose Napoleon's system. Louls conveyed his deep concern for the current state of commerce. He called the United States and Holland both great commercial states, yet weak in naval force in a world that was governed by force. The King gave assurances of his most friendly dispositions toward the American government and people, pledged to Armstrong that, in any event, even war, American citizens and their property within his kingdom, would be safe. According to Louls, his relationship to the Emperor could not induce him to forget the protection which he owed to those who engaged in a regular and falr comerce. 5

Armstrong used this pledge to introduce the subject of reports that American ships had been seized by French cruisers within the territorial jurisdiction of the King. Louls' response was that the shipe had been retaken after the cruisers were beaten off by Dutch gunboats, and the American ships were then returned to their owners or their consignees. On this point, the King had quarreled with the Emperor himself. 6 Louls referred to the system as "bad--so bad that it cannot last--but in the meantime we are the sufferers." 7

In reaponding to Armstrong's remark that the $K i n g$ had placed an embargo on the vessels in his ports, the king replied it had been done merely on account of the Britich Invasion of Walcheren 8 When Armetrong requested a relaxation of the rule to enable him to send despatches to 
his government, the king was extremely agreeable and indicated that one of the Americen vessels could safl imediately for the United States, If Armstrong so wished. 9

In writing to President Madison on August 20, 1809, Armstrons Informed him that among the facts not mentioned in hia public despatch of the same day to the Secretary of state, there was one that the President should know about in particular--King Louls would instruct his ambassador in Paris to join with Armstrong in denouncing the current depradations, and in endeavoring to bring about a change in Napoleon's conduct.

Armstrong left Amsterdam for Parls on the following day, and when he arrived there he was going to attempt a private audience with the Emperor. This suggestion had come from a minister, much in his confidence, who had called upon Armetrong the night before he had left Paris to suggest an experiment, and had of fered his services to bring it about. Since the move for a private audience had to come from the Emperor himself--and as he was not always disposed to grant such indulgences--the plan was to convince his own counsellors of its usefulness. The demand for Armstrong!s passports would be the means most likely to produce the desired effect, and Armstrong would try this. 10

On September 6, 1809, Armstrong returned to Paris. Alghough King Louls had been ancere in promoting friendship and trade with the United States, plane that were contrary to the Emperor's desires did not have much chance for success. Subsequent events and the pecultar nature of Napoleonic Europe, guaranteed that Armstrong's diplomatic gamble vould fall to produce the sought-after effects. ${ }^{11}$ Desplte the 
outcome, Armstrong deserves credit for exploring additional avenues in the interests of his country.

\section{THE ALTENBURG LETTER}

Two lettere from Champagny awaited Armstrong on his return to Paris. One, known as the Altenburg letter, was poorly designed to appeal to Armstrong. In essence, the Altenburg letter was nothing more than a definitive statement of the principles which had and would continue to govern, the Emperor's conduct toward neutral commerce. To this letter, offered as an anwer to the Amertcan propositions, Armstrong belleved that any reply before receiving further instructions from the President, would have been premature. ${ }^{12}$ Although France admitted the principle that the flag covers the merchandise in the letter, other demands were impossible for neutrals to accept. It was only because of the arbitrary acts of the British government that France was forced to adopt measures of reprisal, though very reluctantly. ${ }^{13}$ The note also presented the facade that France was willing to come to terms with Great Britain. However, Napoleon had no thought of making demands that England would accept. He had been, after all, in pursuit of the destruction of English naval power since 1805. As an answer to the American Non-Intercourse Act, Champagny's letter of August 22, 1809, was final. It closed by stating that the ports of Holland, the Elbe and the Weser, Italy, and Spain, would not be allowed to enjoy privilegee of which French ports were deprived. Whenever England revoked her blockades and orders in Counc1l, france would revoke her retallatory decrees. 14 
The other despatch from Champagny expressed a civil hope, hardly felt by the Bmperor, that Armstrong would not for the present carry out his plans for returning to the United States. No doubt Champagny wanted to placate the American minister as much as possible, in light of the Emperor's hostile actions toward American commerce, as well as fear about the possible consequences of the accredited American minister to France leaving with negative impressions. In agreeing to stay until the next spring, Armstrong had to consider his honor, as well as that of his country, especially in light of the Altenburg letter's offensive tone. His conduct on this occasion was certainly not governed by personal motives. He clearly realized his departure might have increased the danger of exposing a great amount of American property in France, Holland, Italy and Naples. 15 He opted to try once more "to open and to mooth the road between the two powers to an anicable adjustment of their differences." 16 Considering the years of frustration he had already experienced, Armstrang's comitment to his duty was truly commendable.

\section{THE PRESIDEITT'S PROCLAMATION}

Shortly after Armstrong responded to the Altenburg letter, he received official word from the Secretary fo state that the recentlyconcluded Erskine Agreement had been disavowed by the British government, and the President had signed, on August 9, 1809, a proclamation reviving the Non-Intercourse Act against Great Britain. ${ }^{17}$ Enclosed in the Secretary'. despatches was a copy of the proclamation, which Armstrong could present to the French government as another example of the 
United States' determination to observe the principles of neutrality, so long as she should consider 1t proper to be neutral. Smith informed Armstrong he was not hopeful that any adfustments between Great Britain and the United States would take place, especially as a result of the British government' condition speciffed in the published letter of Instructions from Canning to Erskine, or of the pretensions as avowed to Pinkney and subsequently communicated by him to the United States, or as a result of the discussions with the new British minister, Jackson. 18

Armstrong communicated this to Champagny in a note of September 16, 1809. He confirmed that the President's proclamation of August 9, 1809, was a consequence of official information that the British Orders in Council of January and November, 1808, had not been repealed in compllance to the agreement entered into by the United States and Erskine. Armstrong stated that he was authorized to assure Champagny that if--as there was reason to belleve--the British government would adhere to the conditions secifled in a letter from Canning to Erskine of January, 1807, no amicable adjustment of the differences then existing between the two powers would take place. Further, the conversations ascribed by the letter to the Secretary in Washington and to Pinkney in London, had been either much mistaken, or grossly misrepresented. Armstrong concluded that he hoped the Emperor would now find reason to belleve that one of two effects might be produced. Either the United States would be made a party to the war against Great Britain, or Great Britain would be compelled to respect the righte of neutral comerce. 19 
Having written to Chempagny according to his inetructions, Armetrong proceeded to air his frustrations in lettere to both Jefferson and Madison. He was none too optimistic, and did not expect any eignificant modification or relief in Napoleon's system. Fresh from new victories, Armstrong understood that this would have an effect on Napoleon's thinking and hence on the United States. From-all past experiences he felt the effects would not be "propitious." He clearly saw that the "danger is that an adherence to the present system will be both quickened and increased by an additional power to enforce 1t." 20 Armstrong once wore saw that taking a firmer posture against both Great Britain and France was the only practical alternative left. As usual, though, his cry for firmer action went unheeded. He expressed his frustration and viewe to Jefferson by stating:

If we submit much longer, we shall eettle this controversy, but we shall certainly not be gainers by doing so... Before you left the presidency, I anticipated this state of things, and offered it as my humble opintion, that you should declare war against France and England. Every hour assures me of $1 \mathrm{t}^{\prime} \mathrm{s}$ [sic] correctness... With this country you will have reconclliation and redress, the moment jou take this step. I feel as certain of it as I do of my existence. And if England will go to the Devil, why should we prevent 1t? She has no clain on our benevolence. 21

The principle of the Vienna Decree had required confiscating American comerce in retaliation for penalties imposed on French ships that knowingly violated the Non-Intercourse Act. Although this rule and the Bayonne Decree eeemed to cover all ordinary objects of confiscation, the Bmperor adopted a supplementary rule that American merchandise was really English property in disguise. In writing to Secretary Smith on November 18, 1809, Armatrong related the incident of a cotton 
oplnner near Parls and the head of a very large establishment who petitioned the Emperor for leave to introduce about 600 bales of American cotton. The petition was rejected and the following words were written upon 1t: "Rejected, as the cotton belongs to American comerce." Armstrong, not disguising his anger, stated that this severity toward American comerce was all the more extraordinary as it was a well known fact that Portuguese cotton--wh1ch was none other than English property--was allowed into France with little difficulty. As American cotton was banished from the market, both the sale and the price of cotton belonging to England were increased proportionately. 22 Having decided to selze all American property that arrived in France on private account, and having taken into his own hands the business of selling this property, as well as of admitting other merchandise through 1icenses, Napoleon protected his own interests by closing the door to competition. To his credit, Armstrong was able to discern a bit of this strategy before it had taken its final form. ${ }^{23}$ He realized that what he had feared with regard to American commerce, had taken place in the North. He predicted that something similar would take place in Spain. He was privately informed that General Loison had left Parls, charged with the purpose of selzing British property, or property suspected of being British, in the ports of Bilbao, St. Sebastian, Passages, among others. The ramifications were quite clear to Armstrong:

The latter part of the rule is no doubt expressiy intended to reach Arerican property. With the General goes a mercantile man, who will be known in the market as his friend and protege, and who, of course, will be the exclusive purchaser of the merchandise which shail be selzed and sold as British. This 1s a 
opecimen at once of the violence and corruption which enter into the present system--and of a piece with this, is the whole business of licenses, to which ( $I$ am sorfy to add) our countrymen lend themselves with great facility.

Caught between Great Britain and France, American comerce was violated mercilessiy. One prohibition crowded upon another. Throughout the rest of the year, Armstrong's correspondence was replete with instances of French seizures and blatant violations of American neutral rights. American consuls and private businessmen throughout Europe frequently requested his intervention, as Napoleon forced his satellites throughout the Empire to implement his system. Having done all that he could, Armstrong felt he had exhausted all possibilities. for peaceably resolving American complaints against France. His call for firmer action, even if it had involved war, would have been the most logical step in forcing the Emperor to make concesw sions. American leadership, with Madison as President, still avoided that inevitable course, and in so doing, subjected America's diplomats to additional abuse and humilfation. The firmest measure of resistance on the part of the United States was simply what Armstrong was able to convey in his persistent protests. 
Notee

Chapter VII

$1_{\text {Adams, }}$, 145-146.

${ }^{2}$ Armstrong to Bourne (Consul-General in Amsterdam), Aug. 7, 1809,

NA Despatches, Vol. XI.

3 Armstrong to Smith, July 26, 1809, NA Despatches, Vol. XI.

4 Armstrong to Smith, Aug. 20, 1809, NA Despatches, Vol. XI.

5 Ibid.

6Ibid.

7 Ib1d.

${ }^{8}$ Ibid. An island at the mouth of the River Scheldt, Holland. Austria was preparing to flght Napoleon, and her primary hopes of support lay in the Peninsular War and a posible Britioh descent upon Hannover, where unrest was developing. However, Britain and Austria were technically at war. The preparations for the expedition were ludicrously unguarded, and on July 28, 1809, when ratification of peace between the two countires at last arrived in London from Vienna and ships set sail, the French newspaper could announce that Walcheren was the point of attack. Official favoritiom gave the command of the 40,000 man army to the Earl of Chatham. He wasted precious days battering the walls of Flushing when he should have made straight for Antwerp, the goal. He finally withdrew to the fever-ridden owamps of the Isle of Walcheren. Only a remnant of the army survived by the end of the year. Hubert 
N.B. Richardson, A Dictionary of Napoleon and His Times (New York, n.d.), $442-443$.

${ }^{9}$ Armetrong to Smith, Aug. 20, 1809, M Despatches, Vol. XI.

${ }^{10}$ Armstrong to Madison, Aug. 20, 1809, Madioon Papers LC, Reel 11.

${ }^{11}$ see Chapter IX, PP. 156-157, note 25 of this thesis.

12 Armstrong to Smith, Sept. 16, 1809, NA Despatches, Vo1. XI.

${ }^{13}$ Champagny to Armstrong, Aug. 22, 1809, ASPFR, III, 325-326.

${ }^{14}$ Ib1d.; Adams, V, 149-150.

${ }^{15}$ Armstrong to Smith, Sept. 16, 1809, NA Despatches, Vol. XI.

16 Armstrong to Chempagny, Sept. 8, 1809, NA Despatches, Vol. XI.

${ }^{17}$ See Richardson, I, 458, for text of the proclanation of Aug. 9 , 1809.

${ }^{18}$ Smith to Armstrong, Aug. 12, 1809, NA Instructs., VII,57-59. For an account of the Jackson affair and negotiations, see Adams, V, $109-132$.

${ }^{19}$ Armstrong to Champagny, Sept. 16, 1809, NA Despatches, Vol. XI. ${ }^{20}$ Armstrong to Jefferson, Sept. 19, 1809, Jefferson Papers LC, Reel 44. See also Armstrong to Madison, Sept. 18, 1809, Madison Papers LC, Reel 11; Armstrong to Smith (private), Oct. 18, 1809, NA Despatches, Vol. XI.

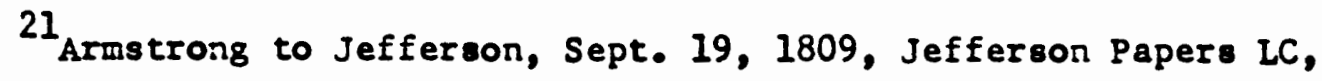
Reel 44.

22 Armetrong to Smith, Nov. 18, 1809, with enclosures, NA Despatches, Vol. XI.

23 Adame, V, 151.

24 Armetrong to Smith, Dec. 10, 1809, NA Despatches, Vol. XI. 
CHAPTER VIII

CABINET REBELLION

The latter part of 1809 and the early part of 1810 produced pressures within France due to the difficulties associated with commercial restriction--particularly a shortage of revenue, as well as the sheer difficulties in the enforcement of the Continental System. Threatened by financial difficulties, Napoleon also found himself confronted with what amounted to Cabinet opposition. As was his habit, he temporarily yielded to the advice he disliked, and promised to do something for French industry. The three princlple ministers were Champagny, Fouché, and Montalivet--newly appointed Minister of the Interior. These three lost no opportunity to advise the Emperor to encourage neutral trade. This advise found further support from Mollien, Minister of the Treasury and from Decrès. I That Armstrong was aware of a struggle among the Cabinet to alter the Continental System, 18 evident in his correspondence. In a despatch to Secretary Smith of December 22, 1809 , Armstrong revealed he had been privy to the fact that on the previous day Fouché had declared to the Governor of the Bank that the Imperial Decrees with regard to the United States were on the verge of modification. Armstrong was careful to caution the secretary of state not to raise his hopes too much, as past experience had been that encouraging signs were deceiving. 2 Nevertheless, by January 6, 1810, Armstrong could report to his ouperior: 
The veil, which for come veeks past covered the proceedings of the Cabinet with regard to neutral comerce, is now 80 far withdrawn, as to enable us to see with sufficlent distinctness, both the actors and the acting. The Ministers of Police and Interfor (Fouché and Montalivet) have come out openly and vigorously against the present anti-comercial system, and have denounced it as "one originating in error and productive only of evil, and particularly calculated to impoverish France and enrich her enemy." While they have held this language in the Cabinet, they have held one of nearly the same tenor out of 1t, and have added (we may suppose on sufficient authority) the most solemn assurances that the Emperor never meant "to do more than prevent the commerce of the United States from becoming tributary to Great Britain; that a new decision would soon be taken by him, on this subject, and that from this, the happiest results were to be expected."3

Exactly what changes rould take place Armstrong could not say for sure, although he had some 1deas. He was forever cautious, recognizing that any new propositions might be considered too liberal by some French officials and would, therefore, receive serious opposition. Armstrong was encouraged, however, by the fact that events in Holland and the needs of Naples might combine to demand at least a modification of the present system. Even at that, Armstrong recognized that he might easily have over-rated the influence of these circumstances:

The Emperor sees things in a way almost pecullar to himself, and It may be that he is at this moment determined on a course which will have the effect of converting a nation of friends into one of enemies;--of expelling from Holland her money, her industry and 4 intelligence, and of dethroning a brother of his own raising.

Once again, Armstrong tried to dampen any unfounded or over-anxious optimism produced by knowledge of Cabinet opposition to Napoleon's enforcement of his system. Having received Smith's despatches of December 1, 1809, informing Armstrong of the rupture with the new British minister, Jackson, 5 Armstrong knew that to those who did not understand the tortuous policy of France of the time, the rupture with Jackson 
might appear to favor the prospects of American business in France. However, Armstrong clearly realized that the exact opposite was more likely. As long as France thought the United States and Great Britain might reach an agreement with each other, France spoke of altering her system, and even 1ssued public and ministerlal declarations supporting this proposal. However, on December 18, 1809, the day the news of the rupture reached Paris, milltary orders were given to selze and confiscate all American vessels and their cargoes which had arrived, or which would arrive, in the ports of Spain. The King of Naples also ordered that all American property captured and brought into his territories should be sold. Armstrong demanded from Champagny the grounds on which this new outrage was based. Armstrong reported that a person in high office had stated this latest outrage was largely political. Looking beyond this explanation, Amstrong deduced that the deficit of over fifteen million francs in revenue the previous year had to be compensated. The obvious course of action, then, was to sap the Americans. Since the United States continued to be at odds with Great Britain, the French could do this with impunity. 6

In the mean time, the renewed confiscation of American ships was contrary to the promise received by Montalivet and Fouché from Napoleon to alter his astem so as to aid their objectives in improving France's comercial position. At a 1088 to invent a theory in which neutrals could be plundered and encouraged at the same time, the Emperor referred the subject to Champagny on January 10. Napoleon requested a complete history of French relations with the United States since the Treaty of Mortefontaine, and ordered the recall of General Turreau, in whom he had 
little confidence, and who he felt should be replaced by a more adept representative. ${ }^{7}$ He remarked to Champagny:

All the measures I have taken, as I have said several times, are only measures of reprisal... It was only to the new extension given to the right of blockade that I opposed the Decree of Berlin; and even the Decree of Berlin ought to be considered as a Continental, not as a maritime blockade, for it had been carried out in that form. I regard it, in some sort, only as a protest, and a violence opposed to a violence... Down to this point there was little harm. Neutrals still entered our ports; but the British Orders in Council necessitated my Milan Decree, and from that time there were no neutrals.... I am now assured that the English have given way; that they no longer levy taxes on ships. Let me know if there is an authentic act which announces 1t, and if there is none, let me know if the fact is true; for once I shall be assured that a tax on navigation will not be established by England, I shall be able to give way on many points. 8

As Adams observes, Napoleon's ministers must have been aware that the Emperor's remarks and the assertions of his comercial pollcy were Inverted only for momentary expediency. The Emperor himself had of ten declared, and caused his ministers to declare, that the Continental System, established by the Berlin Decree, had a broad military purpose quite independent of retallation--that it was aimed at the destruction of England's comerce and resources. Regarding Napoleon's profession of ignorance that England had abandoned her transit duties on neutral merchandise, every minister had to have been aware that only six months earlier, the Emperor had discussed with them measures to be taken in consequence of that abandonment. He had sent them the draft of a new decree founded upon 1t. And he had finally decided to do nothing only because England had again quarrelled with America over Erskine's arrangement. These pretexts certainly could not have been accepted by any of Napoleon's ministers.' 


\section{THE "MOROSE" MINISTER}

In keepling with the Emperor's pretext, Champagny--recently created Duke of Cadore--requested from Armstrong the Information regarding the history of Franco-American relations. M. Petry called upon Armstrong with a message from Cadore stating that the order which had been sent to Spain to seize American shipo was not intended to do anything more than to put them in sequestration, that he had declined answering any letter on the subject because he had hoped that means might have been found to adjust all the points in the controversy between the two countries, that the Emperor was sincerely disposed to be on friendly terms with the United States, and that he (Cadore) wished to know whether Armstrong was, or was not, authorized to conclude a treaty. Armstrong informed Petry that in addition to his plenipotentiary powers, he also had the authority to conditionally revive the Treaty of 1800 . When asked on what grounds Armstrong would act under this authority, the American minister responded in his candid manner by stressing, in writing, the need to restore any sequestered American property. He did agree that any ship which had paid tribute to a forelgn power should be llable to confiscation, but aside from this exception, commerce should be free. 10

Th1s note was carried to Cadore who forwarded it to the Emperor. Within a few hours, the Emperor responded, clearly illustrating his irritation with the American minister's latest display of firmness, and his fallure to be intimidated. Since Armstrong had written the note in French, the Emperor took the opportunity to attack Armstrong's writing 
ability, condeming his lack of proficiency in French. Napoleon informed Cadore that he preferred Armstrong to write in English, "but fully in a manner that we can understand." 11 Furthermore, Cadore was Instructed to send, by special courier, a clpher despatch to the United States requesting General Armstrong's recall. The American government was to be informed that it:

... is not represented here; that its minister does not know French; 10 a morose man with whom one cannot treat; that all obstacles would be raised if they had here an envoy to be talked with. 12

No doubt this latest display of Napoleon's anger was the result of his growing irritation with the American minister who was not easily intimidated by the Emperor or his Court. During the latter part of Arnstrong's tenure in France, he became increasingly unpopular with the Emperor and the French Court. The reasons are obvious. As French outrages toward American commerce became wore frequent and more vicious, General Armstrong's protests were correspondingly frequent and forceful. Although the vast majority of foreign representatives were easily intimidated by the power and presence of the Emperor, Armstrong was not noticeably impressed by the pomp and circumstance surrounding the Emperor. This lack of deference became quite evident to those who attended Court. ${ }^{13}$ Having been unsuccessful in forcing the Emperor to alter his system for the benefit of American comerce, having of ten experienced the peror's failure to keep his promises, and being cognizant of the Diperor's way of responding to the exigencies of the moment, Armstrong saw little to be gained by partaking of the frivolities of Court-o routine which he did not particularly enjoy anyway. Arm- 
strong was, after all, like Jefferson, the product of American republicanism, and, in some ways, not naturally well-suited to engage in Court etiquette. Of Armstrong, William Lee stated:

His conversation is instructive and entertaining; his pen unequalled; and with all this, he has a rudeness of character, a stiff republican frankness about him that is not agreeable to strangers, and is the worst comodity a man can bring to Paris. 14

Many around Napoleon Interpreted Armstrong's Increasing absence from Court appearances as an affront to the Emperor--which it certainly was. It was one way that Armstrong, having exhausted all normal diplomatic channels, denonstrated his contempt for the French violations of American neutral rights. Though in French soclety attention to detall and etiquette were extremely important, Armstrong was not much inclined to indulge in the "little attentions which please...."15 Napoleon was not at all accustomed to such bold protests, especially from a representative of a mere republic. Flnally, Napoleon reached his limit and exploded, using Armstrong's "moroseness" and inadequacy as pretexts to rid himself of such an independent and persiotent minister who refused to demonstrate the desired deference. In order to try to expedite Armstrong's recall, the ald of John Quincy Adams, American minister to Russia, was sought.

In the August 17, 1810 entry in his memoirs, Adams recorded a conversation with a Mr. Six. Six had hinted to Adams that he could state with certainty that much of the difficulty in American relations with France was due to the French government's dislike of General Armstrong. Six believed Adams was the only one who could comunicate this Information to the United States government. Although the French 
government did not doubt Armstrong's character, they did feel that he was "morose, captious, and petulant."16 Adams, possessing no love for Armstrong, did, nonetheless, understand and sympathize with him. Adams stated:

Now, I am afraid that under the circumstances in which the General has been there, the last three years, they would have had quite as much reason to be disastisfied on such ground with me as they can have with him. And I am sure I should think it very ill treatment from him if, upon such vague and loose pretences, he should transmit to the Government a complaint that I was thought morose, captious, or petulant, with suggestions that he himself was the fittest man to take my place. I do not suspect Mr. Six of any 111 design in this affair, for I believe him sincerely and cordially my friend and that of America. Neither do I incline to suspect the Ambassador. I suppose him to be indifferent on the subject, and rather to have fallen in with Mr. Six's opinions than to have spoken from any particular instructions from himself. My own course upon this occasion is plain--to be silent. 17

While attending Court some time later, the French Ambassador to Russia re-affirmed that relations between France and the United States might be settled were someone other than General Armstrong in the American diplomatic post. ${ }^{18}$ During the following month, Adams, having dined at the French Ambassador's country home, was once more encouraged to approach the American government with the complaints regarding Armstrong. The French Ambassador, in referring to the complaints, assured Adams they were nothing that would injure Armstrong's credit at home. He was being criticized because he scarcely ever saw Cadore, never went to Court, and when anything was done by the French government of which he disapproved, he presented "testy" notes, which necessitated answering in similar style. Adams wrote that: "...I now see the whole front of Armstrong's offence is omitting to go to Court, and presenting notes too full of truth and energy for the taste of the 
Emperor. 19

Under normal circumstances, a representative of a foreign country who was not well liked by the host government, would be a handicap to his country's interests. That the United States was a weak maritime power subjected to the unscrupulous actions of the Emperor of France justified Armstrong's conduct. Standard diplomatic protocol had no chance of success. In presenting "testy" notes to the Emperor, and in refusing to attend Court as often as was deemed appropriate, General Armstrong was defending the Interests and the honor of the United States by the only means avallable to hlm. That the Emperor resented Armstrong's forcefulness and requested his recall, may be taken as a distinct compliment to Armstrong's effectiveness under very difficult circumstances. 
Notes

Chapter VIII

1Adams, v, 221-222.

2 Armstrong to Smith, Dec. 22, 1808, NA Despatches, Vol. XI.

${ }^{3}$ Armstrong to Smith, Jan. 6, 1808, NA Despatches, Vol. XI.

4 Ibid. This same Impression of Napoleon was held by William Lee, American consul at Bordeaux. In Nov., 1809, he left Bordeaux and stayed in Paris for five months while he sought to promote his designs of a bridge to be constructed on the Garrone River. His observations of court IIfe and of Armstrong's conduct are useful. See Lee to Mrs. Susan Palfrey Lee, Jan. 13, 1810, Mary Lee Mann, ed., A Yankee Jeffersonian: Selections from the DLary and Letters of Willian Lee of Massachusetts Written from 1796 to 1840 (Cambridge, Mass., 1958), 76-77; hereafter cited as Diary and Letters of Lee.

${ }^{5}$ See Smith to Armstrong, Dec. 1, 1809, NA Instructs., VII, 79-81. 6 Armstrong to Smith, Jan. 10, 1810, NA Deepatches, Vol. XI. 7 Adams, $V, 226$.

${ }^{8}$ Napoleon to Champagny, Jan. 10, 1810, as quoted in Adams, v, 227. 9 Adams, V, 227-228.

10 Armstrong to Smith, Jan. 28, 1810, NA Despatches, Vol. XI.

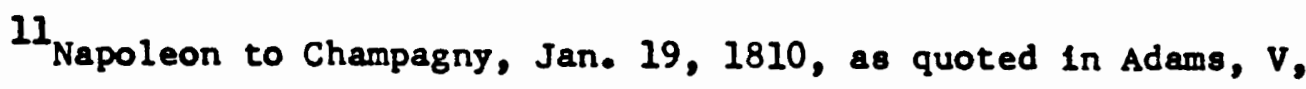
228-119.

12 Ibid. 
13 Lee to Miss Susan Palfrey Lee, Dec. 6, 1809, DLary and Letters of Lee, 90-91; Lee to Mise Suban Palfrey Lee, Dec. 10, 1809, 1bid., 92-94; Lee to Miss Susan Palfrey Lee, Jan. 4, 1810, ibid., 103-105. 14 Lee to Mrs. Susan Palfrey Lee, Jan. 29, 1810, 1bid., 111-113. ${ }^{15}$ Lee to Mrs. Susan Palfrey Lee, Feb. 5, 1810, 1b1d., 114, states that Armstrong would have made an excellent minister to London. ${ }^{16}$ Entry for Aug. 17, 1810, Charles Francis Adams, ed, Memoirs of John Quincy Adams Comprising Portions of His Dlary from 1795 to 1848 . 12 vols. (1874-1877; rpt. Freeport, N.Y., 1969), II, 149-150. ${ }^{17}$ Ib1d., 150-151. ${ }^{18}$ Entry for Aug. 22, 1810, 1bid., II, 151.

${ }^{19}$ Entry for Sept. 13, 1810, 1bid.: Brant, James Madison, V, 151, states, when Armstrong protested the seizures and destruction of American ships, his notes in English "were shortened by the caustic omission of diplomatic gloss." 
CHAPTER IX

\section{NAPOLEON REJECTS CABINET ADVICE: ABUSES CONTINUE}

On January 25, 1810, Armstrong received an invitation to meet with Cadore. The two discussed three subjects: (1) the means for amicably adjusting the differences between the two countries; (2) the motives for the seizure of American vessels and cargoes in Spain; and (3) the condition on which (as offered in Cadore's letter of August 22, 1809) the Emperor would consent to repeal his Berlin Decree. I

With regard to the first topic, Armstrong observed that the points which most engaged Cadore's attention were abuses to which an immediate repeal of the decrees might expose France and the measures first calculated to correct these. As to admitting colonial produce, Cadore informed Armstrong that the Emperor had determined nothing. Armstrong used this occasion to mention that the United States produced one of the articles under that general category in great quantity (cotton), and that they had also begun to produce another (sugar). That many articles not calculated for the markets of Europe--the products of the middle and northern states--were carried to the West Indles and exchanged for sugar, coffee, rum, and molasses--was a trade of basics. The cheapness with which it enabled the United States to supply these articles, should, on the grounds of economy alone, give Americans preference over British omugglers, who would supply them if the United states did not. Cadore responded that the question was no doubt worth considering. 2 
On the second point, Cadore remarked that the orders which had been given with regard to American ships in Spain were a regular consequence of the syotem declared in the letter of August 22, 1809. He stated it was obvious the Emperor could not permit to her allies a commerce which he had denied to France. This would defeat his system and oppress his subjects by demanding from them great and useless sacrifices. If the system were not strictly enforced everywhere, it would not produce the desired effects. Cadore reminded Armstrong that the property selzed had only been sequestered, and as such, was subject of the current negotiation. As American remonstrances had already been sufficiently frequent, and as this meeting was intended for conciliation only, Armstrong thought it more prudent to suppress the obvious answer which he might have given on this point. ${ }^{3}$

Under the third topic, and in conformity to Armstrong's instructions of December 1, 1809, Armstrong asked if the Emperor would revoke the Berlin Decree if Great Britain revoked her blockades. Cadore replied that the only condition required for the revocation would be a previous revocation by the British government of her blockade of France-or part of France--such as from the Elbe to Brest. If the British government would then recall the Orders in Council which had occasioned the Milan Decree, that decree would al so be annulled. ${ }^{4}$

The proposed Vienna Decree, the draft of which was sent to Paris in August, 1809, confiscating all American ships in reprisal for the seizure of French ships supposedly threatened by the enforcement of the American Non-Intercourse Act, was not even alluded to during the discussions with Armstrong, or in discussions among Cabinet ministers. 
It was not until January 25, after Cadore's interview with Armstrong had been reported to the Emperor, that Napoleon at last resorted to the ideal contalned in the Vlenna Decree. This long period of hesitation demonstrated how unfounded Napoleon's plea of retaliation was. However, no other explanation was made for this measure which Napoleon insisted upon implementing, and which Cadore had no alternative but to obey. 5 The Emperor dictated the draft of a note in which the principles of confiscation were laid down:

If American ships have been sequestered in France, France only imitates the example given her by the American government; and the undersigned recalls to Mr. Armstrong the Act of Congress of March 1, 1809, which orders in certain cases the sequestration and confiscation of French ships, excludes them from American ports, and interdicts France to the Americans. It is in reprisal of this last provision that the American ships have been seized in Spain and Naples. The league against England, which has the cause of neutrals for its object, embraces now all the Continental peoples, and permits none of them to enjoy comerclal advantages of which France is deprived. France will permit it in no place where her influence extends; but she is ready to grant every favor to the ships of a neutral power which shall have subjected themselves to a tribute, and shall recognize only the laws of their own country, not those of a foreign government..... If the Minister of the United States has the power to conclude a convention proper to attain the object indicated, the undersigned is ordered to give all his care to $1 t$, and to occupy himself upon it without interruptions. 6

This note was quite remarkable. The proposed Vienna Decree confiscated American ships because French ships were forbidden under threat of confiscation to enter American ports. The note of January 25 suggested a variation from this idea. American ships were to be confiscated in France because they were forbidden to leave America. 7

Despite the almost united pressure within Napoleon's Cabinet to relax restrictions against American commerce, Napoleon clung to the 
objectives of his Continental system. Having tactfully resisted the Emperor's will and reasoning regarding American comerce as long as possible, on February 14, 1810, Cadore finally sent a note to Armstrong as had been ordered by the Emperor. 8 Aware and fearful of Armstrong's responses to the note, Cadore took it upon himself to deviate from the Emperor's precise instructions, and proceeded to alter the text of the note somewhat. In part, Cadore stated:

His Majesty could place no rellance on the proceedings of the United States, who, having no ground of complaint against France, comprised her in their acts of exclusion, and, since the month of May, have forbidden the entrance of their ports to French vessels, under the penalty of confiscation. As soon as His Majesty was informed of this measure, he considered himself bound to order reprisals on American vessels, not only in his territory, but likewise in the countries which are under his influence. In the ports of Holland, of Spaln, of Italy, and of Naples, American vessels have been selzed, because the Americans have seized French vessels. The Americans cannot hesitate as to the part which they are to take; they ought either to tear to pieces the act of their independence, and to become again, as before the revolution, the subjects of England, or to take such measures as that their commerce and Industry should not be tariffed (tarlfes) by the English, which renders them more dependent than Jamalca....9

Adams states that Napoleon had become noticeably reckless when he allowed Cadore to send this note. Every line was either an error, or a misstatement of the truth. Apart from these obvious faults, the note tried to cover too large an area of complaint against the United States. In the projected Vienna Decree, Napoleon had ordered retaliation everywhere for the confiscation threatened by the American NonIntercourse Act. Realizing the impossibility of maintaining that position, he continued to confiscate American ships in France under the old Bayonne Decree, and ordered the eequestration of American ships throughout Europe on the basis that other countries should not enfoy 
the comerce that was denied to France. Cadore's note abandoned this position again, in order to return to the doctrine of the profected Vienna Decree. In order to make it appear reasonable, he claimed that Americans had seized French vessels. 10

Neither the errors nor misstatements nor their purposes escaped General Armstrong. His first inclination was to overlook the obvious discrepancies, and enter at once into a discussion for renewing the Convention of 1800. Armstrong believed this approach would test the sincerity of the overtures being made to $\mathrm{him}$, and perhaps have the effect of drawing from Cadore the precise terms on which the Emperor would acquiesce to American demands. ${ }^{11}$ In a note to Cadore of February 18, 1810, Armstrong presented a plan for renewing the Convention of 1800. He assured Cadore, however, that the United States was then no more disposed to part with her rights than she had been at the time of the Revolution. 12

Armstrong was called on by Petry on behalf of Cadore, and was informed that Champagny had prepared a contre projèt for renewing the Convention of 1800 and submitted it to the Emperor. It would be communicated to Armstrong in a few days. Without placing more optimism upon this declaration than he should, Armstrong took the opportunity to reaffirm the American position to Petry. Any treaty, in any form, which did not provide reparation for the past, as well as security for the future, would neither be accepted by Armstrong, nor ratified by the President or the Senate. 13

However, on March 10,1810, whatever hesitancy Armstrong may have had about 1lluminating the obvious errors and misetatements in Cadore's 
note vanished. Armstrong resorted to speaking in the "morose" manner which the Emperor had resented and about which he had complained. The most reasonable explanation for this sudden change in approach was probably contained in a verbal answer to Armstrong's note of February 21. He was informed that the Emperor had decided to sell the American property seized in Spain. ${ }^{14}$ This information came almost simultaneously with a report from the American consul in Copenhagen, who complained about the sorry state of American comerce, and who was greatly alarmed by the approach of a large French force, as well as a royal order announcing that privateering would immediately commence. The consul had stated: "This may be termed the funeral eulogy of our rights in this country-.......15

Armstrong, in true form, again responded to Cadore's note of February 14. He assailed the many errors and misstatements that related to the history of American relations with France. Armstrong did not deny that since May 20, 1809, the United States had forbidden entry of French vessels into her harbors, nor that confiscation was the penalty attached to violation of this law. He did question, however, why this should offend France. He argued that the right to exclude foreign commerce was a right common to all nations. Could this, then, be regarded as a legitimate excuse for reprisal by a power who argued that the first duty of nations was to defend their sovereignty, and who even denationalized ships of those countries who would not subscribe to that opinion $?^{16}$

Cadore had maintained in his letter of February 14, that the United States had nothing to complain about to France. On this point, 
Armstrong was additionally contentious. He posed the following questions to Cadore: Was the capture and condemnation of a ship driven on the shores of France because of bad weather, nothing? Was the seizure and sequestration of many cargoes brought to France in ships violating no law and admitted to the imperial custom houses nothing? Was the violation of American maritime rights according to existing treatì nothing? There was no mistaking Armstrong's meaning when he stated:

In a word, was it nothing that our ships were burnt on the high seas without other of fence than that of belonging to the United states, or other apology than was to be found in the enhanced safety of the perpetrator? Surely, if it be the duty of the United States to resent the theoretical usurpations of the British orders of November, 1807, it cannot be less their duty to complain of the daily and practical outrages on the part of France.I7

Armstrong clearly left the impression that the United States did have legitimate complaints against France, especially since there were no less than 100 American ships within the Emperor's possessions, or those of his allies. 18

Armstrong systematically refuted the assertion that it was only after the Emperor had been informed of the passage of the American NonIntercourse Act that Napoleon felt it necessary to retaliate on American vessels, not only within his own territories, but also within the countries he controlled. Accurately, Armstrong informed Cadore that no French vessels had actually been selzed by American ships. The law was only a defensive measure and was restricted to the territory of the United States. A measure of reprisal could not possibly be justified by such a law. 19 Armstrong related that when the Non-Intercourse Act was first cormunicated to the Emperor in June or July, 1809, it did 
not excite any unfriendly feeling toward the United States. Far from it, this was immediately followed by overtures of accomodation, which, although they did not produce any positive results, did not make matters wor 8 . 20

In his final remarks to Cadore, Armstrong coyly professed not to know what clrcumstances had arisen that had prompted the Emperor to change his opinion. In a cynical manner designed to embarrass Cadore, Armstrong ended by stating that the "...confidence I feel in the open and loyal policy of his majesty, altogether excludes the idea, that the rule was merely found for the occasion, and made to justify seizures, not otherwise justifiable." 21

In March, 1810, Napoleon had not only convinced himself that the Non-Intercourse Act had just come to his knowledge, producing an outburst in defense of French national spirit, but he also forced Cadore-who knew otherwise--to vouch for the accuracy of the Emperor's menory by his signature. 22

The other logical explanation for the Emperor's conduct could very well have been his need for money. Napoleon's financial needs made him oper to every source which might have helped relieve them. 23

Having firmly lectured Cadore in his note, Armstrong was more convinced than ever that his mission to france could no longer be useful. Inteading to return to the United States during the spring, and not having received as yet a firm promise of a ship from the president, Armstrong applied to the Emperor for one to carry his famlly home. Were this request granted, he wished to leave France around the first part of June. By that time, he would have, hopefully, heard from the Secre- 
tary of state, and, though doubtful, have reached a conclusion of some kind to the long and protracted businese in France. The secretary of State must have been none too encouraged when Armstrong concluded a letter to him stating that there was "no hole or corner of Europe under French influence, whither the Emperor's confiscating orders have not reached." 24 Before he could return to the United States, Armstrong would still have to confront several more turns in the' Emperor's polfcy toward the United States.

\section{RAMBOUILLET DECREE}

On March 23, 1810, Napoleon signed his name to what became known as the Rambouillet Decree. This decree was a paraphrase of the projected Vienna Decree of August 4, 1809. It demonstrated the tenacity with which the Emperor, while seeming to yield to the opposition within his Cabinet, held to his purpose. In order to produce the effect of the Vienna Decree in the Ramboufllet Decree, Napoleon had not only to expel his brother, Louls, from Holland, and to annex that country to France, but he had also to force Fouché, his ablest minister, from the Cabinet. 25 The Ramboufllet Decree was ostensibly a response to the American Non-Intercourse Act of March 1, 1809. It stated that, since May 20, 1809, vessels navigating under the flag of the United States, or owned in whole or in part, by any citizen of that power, which had or would enter the ports of the Empire, or of French colonies, or of the countries occupied by French arms, would be seized, and the money received from their sale would be deposited in the Emperor's surplus fund (caisse d'amotissement). Vessels charged with despatches or with com- 
missions of the government of the Unites States, which did not have either cargoes or merchandise aboard would be excepted. 26

Following the signing of thls decree, not published unt1l May 14, 1810, and after Louis had been forced into the treaty of March 16, 1810, any business not directly related to Napoleon's second marriage preparations came to a halt. During this interlude, Armstrong informed Secretary Smith on April 7, 1810, that he had been promised a ship from the Emperor to transport himself and his family to the United States. Cadore, however, recommended that Armstrong not pin down his departure to any particular day. 28

Although the ports of Prussia were supposedly opened to American commerce, Armstrong advised Smith to avoid ports of Prussia and Denmark until further assurances had been given. ${ }^{29}$ on April 16, 1810, Armstrong warned Smith of the Rambouillet Decree by Informing the Secretary of State that the Emperor had directed the sale of American vessels taken in ports of Spain. The money arising from them was to be placed in the Emperor's calsse privée. The Emperor had also refused to give up the ship, Hero, and ordered that it be brought before the Council of Prizes, where the ship's condemnation was almost assured. ${ }^{30}$ The current precarlous state of American comerce, compounded by King Louis' position, were reported to Armstrong by Mr. Bourne, the American consul in Amsterdam, in a letter of April 27, 1810. In a private interview Bourne had had with King Louls on April 26, the King Informed him that he deeply regretted the measures he had been forced to adopt, relative to American merchandise in the public stores, due to the recent treaty of March 16, 1810. King Louls had resisted until this was no longer possible, and 
hoped to assure the American government of his cordial friendship. Nothing could have given Louis greater satisfaction than to have had the opportunity of cultivating amity and comerce which had for so long existed between the two countries. Louls assured Bourne that he was using every means within his power to obtain the release of the Hero's cargo. 31

For all practical effects, Napoleon treated the United States as if he were at war with her. This antipathy was confirmed when the Rambouillet Decree was published in the official journals of March 14, 1810, though the law had been in effect since it had been signed by the Emperor. Armstrong made the official promulgation of the decree known to Smith in a despatch of May 24, 1810. He informed Smith that four commissioners had been sent to Amsterdam with orders to take possession of American property found there, in accordance with Article 10 of the treaty between Holland and France. Further illustrating the futility of the American position, Armstrong reported that several American ships and cargoes for which compromise had been previously worked out under the sanction of the Council of Prizes were again seized to satisfy the provisions of the new decree. 32

THE NOH-INTERCOURSE ACT REPEALED, AND MACON'S BILL NO. 2 PASSED

News of Napoleon's most recent selzures and confiscations greatly upset Madison and the American government. In a letter to Jefferson of May 25, 1810, the President expressed his feelings about this: "The late confiecation by Bonaparte comprise robbery, theft, and breach of trust, and exceed in turpitude any of his enormities not wasting human 
blood." 33 The Non-Intercourse Act, like the Embargo Act, had obviously failed to bring about the desired response from either France or Great Britain. Like the Embargo, Non-Intercourse had placed a great strain on American comerce. As it was scheduled to expire naturally on May 1, 1810, the eleventh Congress allowed it to do so, replacing it with Macon's B111 No. $2 .^{34}$

Macon's Bill No. 2 was the last Congressional measure intended to counteract, through comercial interest, the encroachments of France and Great Britain. The first had been the Non-Importation Act of April, 1806. The second was the Embargo Act with its supplements dating from December, 1807. The third was the Non-Intercourse Act of March 1, 1809. The fourth was Macon's B1ll No. 2. Each year had witnessed a new experiment in peaceable coercion, as the philosophy of Jefferson and Madison was put Into effect. After the climax of the Embargo Act, however, each subsequent act merely represented a weakening faith in the policy, until Macon's Bill No. 2 marked the last step toward the admitted fallure of commercial restrictions as a substitute for war. ${ }^{35}$

This latest law re-opened American trade with all the world, though it excluded French and British warships from American waters. The most 1mportant feature of the bill, however, stated that if either England or France agreed to respect American rlghts, either by revoking or by modifying their edicts before March 3, 1811, the President could again apply Non-Intercourse to the nation that had not revoked its edicts. This would be done after an interval of three months had elapsed, allowing the violating nation an opportunity to follow the example set by its rival. 36 
Armstrong was informed of the passage of the new law and instructed to tell the French government that the Non-Intercourse Act, the pretext given for the seizing and confiscating of so many American vessels and cargoes, no longer existed. The Administration hoped that its prospects might be improved with this repeal, and felt that France might be encouraged by the President's willingness to revive Non-Intercourse against Great Britain if France would only revoke her offending decrees. 37

Following this set of instructions, another set was drafted telling Armstrong that if Pinkney's efforts in London to secure the revocation of the British blockades should fall, Armstrong was to formally relate to the Duke of Cadore that the Non-Intercourse Act no longer existed. If, as Cadore had stated in his letter of February 14, 1810, France was ready to do justice to the United States in exchange for a pledge on the part of the United States not to submit to the British edicts, then the President was ready to revive the Non-Intercourse Act against Great Britain. However, it would not be enough for France to agree only to stop molesting American commerce. Repeal of the French edicts would have to coincide with "a satisfactory provision for restoring the property lately ourprised and selzed." 38

The likelihood of Armstrong effecting revocation of the French decrees was extremely silm. Even more unlikely was the possibility of securing reparations for past injuries. This was wishful thinking on the part of the Administration.

When the text of the Ramboulllet Decree arrived in the United States in mid-July, a week after the last set of instructions had been 
sent to Armstrong, cries for war vere heard from numerous American citizens. It was probably a lack of adequate milltary and naval preparation that restrained the government from taking this step. ${ }^{39}$ (England had not offered any reasons to endear herself to the United States ei ther.)

This last measure of peaceable coercion passed by Congress was also the weakest of all the measures. Ironically, it was the only piece of American economic legislation which really had any effect on Napoleon. 40 Although theoretically impartial, Napoleon saw Macon's Bill No. 2 as a virtual surrender to British maritime policy. Since the Eritish llavy dominated the seas, whatever trade the new law allowed would in fact be subject to british control. 41 It threw open to British trade a market in the United States which alone would compensate England for her 1088 of trade with France and Holland. Macon's Act made the Milan Decree useless. ${ }^{42}$ The evidence indicates that Napoleon did not decide upon a radical reconstruction of his Continental system until his hand had been forced by this unexpected turn in American policy. The reconstruction first entailed "permits" for American ships, and then a conditional repeal of the Berlin and Milan Decrees. 43 
Notes

Chapter IX

${ }^{1}$ Armstrong to Smith, Jan. 28, 1810, with enclosures, NA Despatches, Vol. XI. In Smith's instructions to Armstrong of Dec. I, 1809, Armstrong was instructed to inquire about the third point. See Smith to Armstrong Dec. 1, 1809, NA Instructs., VII, 79-81.

2 Armstrong to Smith, Jan. 28, 1810, with enclosures, NA Despatches, Vol. XI.

3 Ib1d.

4 Ibid.

5 Adans, v, 230.

6 Projet de Note, Jan. 25, 1810, as quoted In Adams, V, 230-231.

7 Adams, v, 231.

${ }^{8}$ Adams, V, 232. Armstrong to Smith, Feb. 17, 1810, with enclosures, iA Despatches, Vol. XI.

9 Duke of Cadore to Armstrong, Feb. 14, 1810, ASPER, III, 380-381.

10 Adams, V, 232-233.

11 Armstrong to Smith, Feb. 18, 1810, NA Despatches, Vol. XI.

12 Armstrong to Cadore, Feb. 18, 1810, NA Despatches, Vol. XI.

${ }^{13}$ Armstrong to Smith, Feb. 25, 1810, iA Despatches, Vol. XI.

14 Armstrong to Smith, March 10, 1810, NA Despatches, Vo1. XI.

${ }^{15}$ Forbes to Armstrong, March 3, 1810, NA Despatches, Vol. XI.

16 Armstrong to Cadore, March 10, 1810, ASPFR, III, 381-382. 
${ }^{17}$ Ibid., 382.

18 Ibid.

19 Ibid.

${ }^{20}$ Ibid.

$21_{\text {Ibid. Madison was indignant as a result of the violence and }}$ outrages perpetrated on American property. He approved of the language used by Armstrong in his note to Cadore of March 10, 1810. Smith to Armstrong, June 5, 1810, NA Instructs., VII, 97-98.

${ }^{22}$ Adams, V, 235-236.

${ }^{23}$ Ibid., 236. Mahan, I, 145, states that Napoleon was always poverty-stricken.

${ }^{24}$ Armstrong to Smith, March 24, 1810, with enclosures, NA Despatches, Vol. XI.

${ }^{25}$ Adams, V, 236. Louis had refused to seize American ships at Amsterdam, thus forcing Napoleon to the conclusion that Holland must be annexed to France. Threatened with war, Louis was obliged to journey to Paris where he was coerced into signing a treaty on March 16, 1810, in which a secret provision called for the seizure of American property. Fouché opposed the annexation of Holland, and tried to prevent it. He believed that nothing but peace with England could put an end to the Emperor's experiments with the welfare of France. In a scheme with which he approached England through an agent named Fagan, he suggested that if Great Britain would abandon Spain, France would join in creating, from the Spanish-American colonies, a monarchy for Ferdinand VII, and from Loulsiana, a kingdom for the Bourbons of France. Almost simultaneous to Fouché's advances, Napoleon was secretly working advances of his own 
toward England. Armstrong's note to Smith of Jan. 10, 1810, reveals that Armstrong was knowledgeable about Fouché's scheme. See Armstrong to Smith, Jan. 10, 1810, NA Despatches, Vol. XI. Both Fagan and Napoleon's agent went to England and held interviews with British ministers in early Feb., 1810. However, their proposals were quickly dismissed. On April 27, Napoleon and his new Empress set out for Holland. In the course of the journey, Napoleon learned of Fouché's scheme. On June 3, Fouché was disgraced and exiled to Italy. Louis, however, still resisted putting into effect the decree. On June 24, French troops were ordered to occupy Amsterdam, and on July 3, Louis abdicated and took refuge in Germany. On July 8, Napoleon annexed Holland to France. For a good account of the events surrounding Loufs and Fouche, see Adams, V, 236-242.

26 ASPFR, III, 384.

27 Armstrong to Smith, April 4, 1810, State Papers and Publick Documents of the United States....," 3rd ed., II vols. (Booton, 1819), VII, $463-464$. ${ }^{28}$ Armstrong to Swith, April 7, 1810, NA Despatches, Vol. XI. 29 Ibid.

${ }^{30}$ Armstrong to Smith, April 16, 1810, NA Despatches, Vo1. XI.

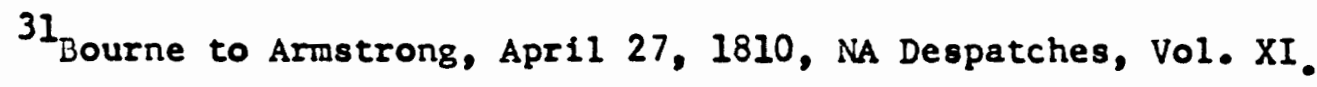
32 Armstrong to Smith, May 24, 1810, NA Despatches, Vol. XI. ${ }^{33}$ Madison to Jefferson, May 25, 1810, Letters and Other Writings of James Madison 4 vols. (New York, 1884), II, 478. 34 Annals, 11th Cong., 2nd sess., pp. 2512-2583. 35 Adams, V, 195-196. 36 Annals, Ilth Cong., 2nd sess., pp. 2582-2583. 
158

${ }^{37}$ Smith to Pinckney and Armstrong, May 4, 1810, NA Instructs., VII,

90; Smith to Armstrong, May 22, 1810, NA Instructs., VII, 96-97. See also Smith to Armstrong, June 5, 1810, NA Instructs., vII, 97-98. ${ }^{38}$ Smith to Armstrong, July 5, 1810, NA Despatches, Vol. XI. The original draft was pencilled by Madison and 18 found in Madison Papers LC, Reel 12 .

${ }^{39}$ stockier, 504.

40 Bemis, History, 154.

41 DeConde, History, 99.

42

Adams, V, 244.

43 Melvin, 194. 
CHAPTER $\mathrm{X}$

DECREES "REPEALED"

Napoleon, recognizing his Continental system was in need of change, created a Council of Commerce and Manufactures on June 6, 1810. 1 Through this council, orders and decrees designed to meet the needs in the license system were issued in an effort to bolster the French economic position. Oftentimes these decrees were duplicated, and the meaning of a public decree was often affected by some secret decree or order, contributing to civil confusion. ${ }^{2}$ When the council was created, further tariff revision had already been contemplated, either as a corrective measure for the high prices of colonial goods and raw material, or as a sefe-guard for French industry, with, of course, an incidental revenue objective. The first definite step toward such a purpose, however, seems to have been instructions to Montallvet on June 18, 1810, to prepare a report on the tariff, and to include certain trade statistics. 3

In attempting to meet the needs of France as he saw them, and desiring to prevent the United States from becoming an ally of Great Britain, Napoleon hit on a plan he thought would accomplish his objectives. He pretended to make satisfaction for the United States, at the same time maintaining his system in order to hurt Great Britain. The actual reasons Napoleon instituted changes in his Continental System at this particular time are debateable. Quite possibly the Emperor was 
alarmed by the reports of increasing anti-French sentiment in the United States. 4 Additionally, he may have seen an opportunity to embroll the United States with Great Britain by relaxing his decrees. He also recognized that the European economy required goods which only Americans could provide. 5 However, the Emperor was aware that American ships which did cone to France would risk being sequestered, because all of them would either have been visited by English ships, or would have touched in England. Napoleon realized it was probable that few American ships would venture into French ports without knowing for sure what France meant to do with them. 6

Napoleon recognized that he could do one of three things: maintain his decrees, (2) expressly revoke them, or (3) appear to revoke them while in fact maintaining them. Characteristically, the Emperor opted for the third course of action.

Since Napoleon's primary motive at the time was commercial, the Emperor devised a plan to withdraw his decrees as they affected American conmerce. Deviously, Napoleon proposed to replace them with customs regulations that would effectively prevent the importing of goods which he did not want or need, or which were primarily the products of British colonies. The repeal, then, would be nominal and, in essence, allow the system to remain intact while appearing to have been changed or dropped. Napoleon further explained his projected scheme:

This situation will have no influence on the customs legislation, which will always regulate arbitrarily duties and prohibltions. The Americans will be able to bring sugar and coffee into our ports,--the privateers will not stop them because the flag covers the goods; but when they come into a port of France, they will find the customs legislation, by which we shall be able to say that we do not want the sugar and coffee brought by 
the Americans because they are English merchandise; that we do not want tobacco, etc.; that we do not want such or such goods, which we can as we please class anong prohibited goods. Thus it 18 evident that we should commit ourselves to nothing. 7

The Emperor issued a decree, passed on July 5, but not then promulgated, recognizing neutral rights by issuing licenses under the name of "permits" for thirty American vessels. The legal thirty vessels carrying cargoes consisting of cotton, potash, codfish, indigo, or logwood, would come from one of two ports--New York or Charleston-mand would bring with them certificates of origin. 8 The ships could only enter at one or two designated French ports, and would be required to take, in return, wines, cognac, silks, and other French goods equivalent to the value of the incoming cargo. 9

When Armstrong became aware of this decree, he was upset with It and with Napoleon's scheming. Armstrong was further suspicious of Napoleon's motives and more certain of the Emperor's lack of good faith when told that it was not a convenient time for Armstrong to press for the fulfillment of the Emperor's earlier promise to provide a ship for the Minister's return to the United States. Armstrong stated: "Such was the fact--but what are promises now a days?"10

Napoleon's new system apparently was founded upon the decrees of July 3, 5, and 25, 1810. These three decrees may be regarded as the component acts for the reconstruction of the French navigation system upon the Ifcense trade. The first decree blocked out the general plan and worked out the importation features except for neutral countries supplying their own goods. The decree of July 5 on American permits remedied this oniseion, for both imports and exports from neutrals. 
The decree of July 25 filled out the scheme by bringing all French export trade under uniform regulations. ${ }^{11}$ This third decree forbade ships to leave a French port for a foreign port without a license, which, in the Emperor's eyes, gave that ship the character of being French. 12 In other words, the Enperor's scheme was founded on and left intact his Berlin and Milan Decrees, except for the license feature. The licenses themselves were classified in thirty different series: for the ocean, the Mediterranean, England, and so on. They designated the cargoes to be carried inward and outward. They made no distinction between neutrals and enemies. The license that authorized a voyage from London was the same, except for its serles, as that which covered a cargo of cotton from Charleaton. Any distinction was limited to imposing on the neutral additional trouble to prove that his goods were not English. In theory, the importation of such English merchandise as would have relieved England's distress was forbidden, and the exportation of French merchandise was encouraged, not only in order to assist French industry, but also in order to drain England's specie. Sugar, coffee, and cotton from the colonies were especially prohibited, but when captured by privateers or confiscated on land, colonial produce was first admitted to the custon-house at a duty of fifty per cent, and then sold for the benefit of the Imperial treasury. 13

Napoleon dmposed this system and tariff on all countries under his control, including Switzerland, Naples, Hamburg, and the Hanse Towns, while he exerted all his influence to force the same policy on Prussia and Russia. As far as it concerned the United States, the only neutral left, the system classified American ships elther as English 
when unlicensed, or as French when licensed. This new oystem, another form of the Berlin and Milan Decrees, was in some respects more offensive than the original. 14

THE CADORE LETTER AND TRIANON TARIFF OF AUGUST 5, 1810

Although news arrived in Paris that the American Non-Intercourse Act had been repealed and Macon's Bill No. 2 had taken its place, Armstrong himself falled to receive official notice of these events from his government. However, through an American who had recently been in London, Armstrong received despatches from Pinkney, which Included a copy of the Act of May 1, 1810. Around July 9, Armstrong communicated the passage of Macon's B1ll No. 2 to Cadore as reported in a newspaper. Cadore responded that such an unoffictal form could not be made the basis for any governmental proceedings, but he, nevertheless, forwarded the newspaper to the Emperor. ${ }^{15}$ For three weeks Napoleon made no decision on the subject of the American act, probably due to his pre-occupation with the annexation of Holland, and formulation of his tariff system. Then, on July 31, 1810, the Emperor disregarded Cadore's sense of proper form and, ostensibly as a result of Macon's Elll No. 2, decided that his Berlin and Milan Decrees would be repealed as of November 1,1810 . In a note to Cadore, the Emperor made known his decision, and instructed Cadore accordingly:

After having much reflected on the affairs of America, I have thought that to repeal my Decrees of Berlin and Milan would have no effect; that it would be better for you to make a note to Mr. Armstrong by which you should let him know that you have put under my eyes the detaile contained in the American newspaper; that I should have liked to have a more official comunication, we may regard this as offictal,--he can consi- 
der that my Decrees of Berlin and Milan w11 have no effect, dating from November 1; such Act of the American Congress, on condition that (a condition que) if the Britioh Council does not withdraw 1 ts Orders of 1807, the United States Congress ahall fulfil the engagement it has taken to resestablish its prohibitions on British comerce. This appears to me more sultable than a decree which would cause shock (qui ferait secousse) and would not fulfil my object. This method appears to me more conformable to my dignity and to the serlousness of the affair. 16

On August 2, 1810, the Emperor h1mself dictated the letter that was sent to Armstrong on August 5. He made numerous changes in its text during the three day interval, but at last it was signed and sent to the American Embassy. 17 on August 5, 1810, Cadore delivered what became known as the Cadore letter. It has generated a great deal of historlcal debate, and has had a significant effect upon the subsequent course of American relations with both France and Great Britain.

The letter essentially relterated what Napoleon had written to Cadore on July 31. Cadore Informed Armstrong that he had placed the newspaper containing the Act of Congress of May 1 before the Emperor, and that the Emperor had expressed the hope that this act, as well as all other acts of the United States government which interested France would always be made known officially to him. According to Cadore, the Emperor had remarked that, in general, he only had knowledge of American acts indirectly, and then only after a long interval which was quite inconvenient, ${ }^{18}$ an obvious gross misstatement of fact.

Cadore wrote that the Emperor had applauded the Embargo laid by the United States, although it had the effect of hurting France, and caused her to lose the colonies of Martinique, Guadaloupe, and Cayenne. Despite these adverse effects, the Emperor did not complain. He made 
this sacrifice to the principle which had caused the Americans to lay the Embargo, inspiring them to restrict themselves rather than submit to the laws of Great Britain who vought to make herself the tyrant of the oceans. 19

Cadore further stated incorrectly that the Emperor had not known about the passage of the Non-Intercourse Act of March 1, 1809 until very recently. He referred to it as most injurious to the interests of France, interdicting to American vessels the comerce of France, while at the same time authorizing that to Spain, Naples, and Holland. It also announced confiscation against all French vessels which would enter the ports of America. Reprisal for confiscation against French vessels was, therefore, a right, demanded by the dignity of France, a circumstance on which it was impossible to compromise. 20

Seeming to have presented a defense of past French actions, the Emperor, through Cadore, stated that the United States had in fact retraced her hostile steps by revoking the Act of March 1, thus opening the ports of the United States to French commerce. In short, Congress had engaged itself to oppose the belligerent which continued to refuse to acknowledge the rights of neutrals. Responding to the new circumstances, Cadore informed General Armstrong that he was authorized to declare that:

...the decrees of Berlin and Milan are revoked, and that after the lst of November they will cease to have effect; it being understood that, in consequence of this declaration, the English shall revoke their orders in council, and renounce the new principles of blockade, which they have wished to establish; or that the United States, conformably to the act you have just cormunicated, shall cause their rights to be respected by the English.

It is with the most particular satisfaction, sir, that I 
make known to you this determination of the Emperor. His majesty loves the Americans. Their prosperity and their comerce are within the scope of his policy.

The independence of America is one of the principle titles of glory to France. Since that epoch, the emperor 18 pleased in aggrandizing the United States, and, under all circumstances, that which can contribute to the independence, to the prosperity, and the liberty of the Americans, the Emperor $y_{111}$ consider as conformable with the interests of his empire. ${ }^{21}$

Armstrong must have found these professions of love almost comica1. How could a man who had seized and even burned American vessels, confiscated the cargoes, and imprisoned the crews profess to actually love Americans? No doubt this was merely another scheme designed to camouflage his true intentions. Napoleon's true affections toward Americans is better fllustrated by the fact that, on the very day of the Cadore Letter, the Emperor put into effect his secret Trianon Tariff, which established customs regulations effectively halting imports. 22 Napoleon's objective was to diminish the duties rather than to augment them, yet to maintaln the colonial products at the price which they were in France so that goods from America could enter into competition with them. ${ }^{23}$ The Trianon Tariff of August 5 was actually evidence that the old Continental system of rigid exclusion, of a comercial crusade against England, had failed. While it had nominally been abandoned, it had really only given way to a new system of regulation, to navigation acts, and to a continental protective system aimed at England and her colonial products. 24

Simultaneous to the introduction of the secret tariff, Napoleon, in a secret decree of the same date and name, ordered the sale of sequestered American ships in French ports which had arrived between May 20, 1809 and May 1, 1810. From August 5 to November 1, 1810, 
American ships would be allowed to enter French porte, but they had to obtain a license before they could discharge their cargoes. ${ }^{25}$ This decree was never published, nor was Armstrong ever informed of Its existence. Albert Gallatin accidentally discovered a copy of the decree some ten years later when he was Minister to Par18, and realized what effect the knowledge of this decree might have had on the course of American affairs if it had been known at the time:

...no one can suppose that if it had been communicated or published at the same time [as Cadore's letter], the United States would, with respect to the promised revocation of the Berlin and Milan decrees, have taken that ground whlch ultimately led to war with Great Britain. It is indeed unnecessary to comment on such a glaring act of combined injustice, bad faith, and meangess as the enacting and concealment of that decree exhibits....

Napoleon, as usual, had no intention of actually alleviating the American position, though he tried to appear to do so. Armstrong quickly informed the secretary of State of the contents of Cadore's letter of August $5 .^{27}$ On the same day, Armstrong also wrote to President Madison, further explaining Cadore's letter as he saw it. He noted that, on July 27, advices had been received from England stating that Congress had been called Into special session. The object of this spectal session was thought to be a declaration of war against France. Although Armstrong may have overrated the Influence produced by this report, he felt that such a report, if credited at all, would not fall to produce considerable interest. Armstrong informed the President that repeated inquiries had been sent to him, wanting to know what he knew and what he belleved. Armstrong disguised nothing. Sensing a possible position of strength, he tried to make the moot of 
his position by being as completely honest to the inquirers as possible. He told Madison that he knew the inquirers to be respectable men and likely, from their connections with the Unfted States, to have been well informed. Armstrong told them that he had seen the letters, that he believed a special session was indeed likely, and that if it did take place, it could only be for the purpose of declaring war as had been suggested, since the Preeldent's powers were competent for any course of action short of a declaration of war. M. Petry was also of the same opinion. According to Armstrong, the revocation of the decrees, as stated in Cadore's letter, proved two things: (1) although France had no objection to frightening the United States, she had no desire to actually fight her. France, whose ambition, gigantic and terrible as it was, would find herself fully occupied for twenty years to come in establishing her dominion over Europe; and (2) tired of expedients in which she had lost character and money, and under which her people were fast becoming impoverished, France was again returning to a certain degree of justice, moderation, and good sense. 28

Armstrong further informed the President about the new Trianon Tariff which amounted to nothing less than fifty per cent of the marked price of articles. It made no difference to French officials if Armstrong told them that this would be self-defeating by keeping the articles enumerated out of the market, or even worse, by smuggling them into 1t. Armstrong had no doubts that the new tariff would be adopted. In concluding his letter to the President, Armotrong once more Indicated his intention to oall for the United States, this time by 
October 1 from Bordeaux. 29

REACTION IN AMERICA

News of the Cadore Letter first reached Washington, D.C. on September 25, 1810, in unofficlal form from Pinkney in London, in a newspaper statement reporting the letter from Cadore to Armstrong. 30 Exactly what transpired within the Cabinet is unknown. If Gallatin was consulted, he left no trace of his opinions. Robert Smith within a year would attack Madison publicly for the course that was pursued, and would give the impression that it was a result of Madison's judgment alone. ${ }^{3 l}$ One may ask what the reasons were for Madison issuing his proclamation of November $2,1810$.

One plausible explanation was that, in order to make use of the provisions contained in Macon's BIIl No. 2, Madison had to proclaim that France had indeed revoked or modified her decrees so that they ceased to violate the commerce of the United States. At the time, all Madison had was an unofficial copy of Cadore's letter. He certainly was not justified in making any sort of decision based upon the supposed revocation of the decrees. It was certainly not correct to say that the decrees were revoked when their effect was not to cease until November 1, and thenonly if one of the two conditions vere fulfilled. 32 In a legal sense, the decrees, which had been promulgated as fundamental laws of the land, could not be repealed simply by a note from the Minister of Forelgn Relations to the diplomatic representative of a foreign power. 33

Subsequent evente have clearly demonstrated that Napoleon had no 
Intention of actually repealing his decrees, although he wanted Madison to belleve that they had been. In accepting Napoleon's deception, Madison walked into the trap and took Congress with him. ${ }^{34}$ Napoleon "promptly bamboozled" Madison with false declarations of the revocation of his decrees. ${ }^{35}$ What then Induced Madison to act 80 impulsively and proclaim on November 2, 1810, that the Cadore letter was enough to satisfy the criteria that the decrees of Berlin and Milan had been revoked?

Perkins, somewhat sarcastically, states with confidence that Madison's actions were similar to those that had:

...characterized fish from time immemorial, President Madison belleved it possible to feed on the balt without swallowing the visible hook. Delay would encourage Napoleon to pull his Iine from the stream, whereas immediate acceptance might cause Great 36 Bitain to cast even more appetizlng food upon
the water. By grasping at this opportunity, Madison hoped to be able to force Great Britain into repealing her decrees, especially as it had been two years since he had told Erskine that the United States would be fully justified in having recourse to hostilities with either belligerent, and that she only hesitated to do so from the difficulty of contending with both. ${ }^{37}$ From approximately the end of 1807 until 1810, the aim of the American government had been to divide the belligerents by inducing one or the other to revoke its edicts, so that the example would lead to a revocation by the other, or the contest would at least be ilmited to a single one. ${ }^{38}$ This may be seen in a letter from Smith to Pinkney of October 18,1810 , in which the Secretary stated:

It ought not to be doubted that this step of the French Government will be followed by a repeal on the part of the 
British Goverment of 1 ts orders in Councll. And if a termination of the crises between Great Britain and the United States be really intended, the repeal ought to include the system of paper blockades, which differ in name only from, the retaliatory system comprized in the orders in Counc11. 39

Although no officlal correspondence had yet been received from Armstrong, Smith did nonetheless state that, when it was received, and if it corresponded with the printed matter contained in Pinkney's despatch, then Pinkney was to let the British Government understand that, on November 1, the President would issue his proclamation in conformance with the Act of Congress, and Non-Intercourse would be revived against Great Britain. ${ }^{40}$ On October 31,1810 , Smith sent for Turreau and informed him of the decision that had been reached by the President and the Cabinet. He stated that the Executive was:

...determined not to suffer England longer to trammel the comerce of the United States, and he hopes to be sustained by Congress. If, then, England does not renounce her system of paper-blockades and the other vexations resulting from it, arrangement with that Power is to be expected; and consequently you will see, in two days, the President's proclamation appear, founded on the provisions of the law requiring the non-intercourse to be enforced against either nation which should fall to revoke its edicts after the other belligerent had done so.....Although we have received nothing directly from Mr. Armstrons on this subject, which is doubtless very extraordinary, we consider as sufficient for the Government's purposes the communication he made to Mr. Pinkney, which the latter had transmitted to us. 41

On the very same day this interview with Iurreau occurred, New York newspapers announced the arrival of the despatch schooner, Spencer, with despatches from General Armstrong. Released from sequestration at Armstrong's request, the ship had taken seven weeks to disentangle herself from French bureaucratic red tape, and to make the crossing from Bayonne, having left on September 29. Disembarking at New York, 
the despatch carrier travelled almost $250 \mathrm{mlles}$ overland in two days in order to reach Washington before the President's proclamation was 18sued. $^{42}$ Upon examining the despatches, Madison and the Cabinet found two letters of July from Armstrong to smith, confirming press reports that American trade would be Ilmited to 30 vessels carrying French Iicenses; Cadore's letter of August 5, with a short cover note to Secretary Smith, and a private letter to President Madison concerned with 1t; a printed copy of the August 5 tariff; and letters dated as late as August 24 on various other subjects. 43

President Madison certainly had grounds to justify withholding the proclamation. In spite of the questionable evidence that the French decrees had actually been revoked, the President accepted that evidence and issued his proclamation on the basis of the revocation of the decrees. He, therefore, was moet responstble for what then transpired. Having made the decision, on November 1, to accept Cadore's letter as proof of repeal of the French decrees, within the meaning of Macon's Bill No. 2, the President, on November 2, 1810, 1ssued his proclamation, declaring that:

... it has been officially made known to this Government that the said edicts of France have been so revoked as that they ceased, on the said first day of the present month, to violate
the neutral commerce of the United States.

Also on November 2, instructions were sent to Armstrong, which included a printed copy of the President's proclamation. Armstrong was to let the French Government know that the proclamation had been issued on the grounds that the repeal of these decrees included revoking all the edicts of France which actually violated American neutral rights, 
and that in issuing the proclamation, the requisition. In the letter of July 5 to Armstrong, on the subject of sequestered property, would have been satisfied. 45

Madison's decision was rash, but to him the moment seemed fleeting. Napoleon's character was such that, if the United States had delayed or haggled, the Emperor could have immediately swung back to the decrees that he had so tenaciously defended. ${ }^{46}$ To Madison, the repeal of the French decrees promised at least an extrication from the dilemma of a shameful peace, or a war with both the great belligerents. In 1810, he was not confident about the prospects of a British repeal. He took consolation in the thought that, even if the desirable goals could not be attalned without war, the country would at least unite when the time came to assert its rights. Writing to Jefferson, on October 19, 1810, Madison stated: "We hope from this step the advantage of at least having but one contest on our hands at a time." 47 Unfortunately for Madison, he, like his predecessor, had not learned that $\operatorname{logic}$ did not always govern men's decisions. Madison ignored American partisanship and Anglophilia, and expected the people to support the goverment's demand for justice from England. The government also minimized the emotional commitment of England to her Orders in Counc1l. The President had hoped that Great Britain would seek material advantages through concession; if she did not, he expected Perceval to be too sensitive to domestic criticism to prosecute an armed conflict with the United states. 48 "These miscalculations grew out of Madison's central mistake, a bellef that Napoleon could be trusted to execute the bargain he offered." 49 However, Madison was not 
so idealistic as to expect generosity, and the instructions of November

2 showed that he was at least apprehensive that Napoleon would naxrowly interpret the Cadore letter. Nevertheless, Madison did expect Napoleon to recognize the advantages that would come from uniting the United States against England, as well as the potential disadvantages of insulting people already balky due to Continental abuses. "Hindsight shows us that most of them [Madison'scalculationd] were wrong, but the initial decisions understandable. The President is most to be condemned for failing to revise his analysis when new facts became avallable." 50 Again, the President must be held responsible for his actions, especially in light of reports from Armstrong's successors, Jonathan Russell and Joel Barlow clearly indicating that the decrees had not been repealed. When Madison, in spite of the evidence, allowed NonIntercourse to be reinstated on February 2, 1811, he had committed the United States to Napoleon's Continental System, against Great Britain, which was likely to draw the country into a war with Great Britain. More than likely, Madison allowed this to happen, in part, because he had already suffered a great deal of humillation over the Erskine Agreement. He refused to admit that he might have been wrong again. 51 Melvin sums up the position which confronted Madison and the United States:

When President Madison by his proclamation of 2 November 1810 and 2 February 1811 met the corditions of Cadore's 5 August letter, by which Napoleon had accepted the challenging repeal of the non-Intercourse law, the outcome was a pretty problem for diplomatic haggling.... In American diplomacy it was a perlod of small honor, and much watchful waiting. It was a situation which invited the bullying of Wellesley, and the double-dealing of Napoleon. 52 
ARMSTRONG CRITICIZED

Ao might have been expected, Armatrong's performance during the last couple of monthe of his diplowatic career in France has Indeed been criticized. 53 some criticism may be justified. However, major critics have been excessively hareh. The reasons for this criticism need to be examined more closely to more accurately assess Armstrong's performance in France.

The most common complaints against Armstrong's performance during his last two months in France are: (1) After having received the Cadore letter, Armstrong refrained from stating anything more than was necessary in his reports. He falled to express an opinion as to the faith of the Emperor's promise. He also falled to make further protests against actual reprisals, keeping silent so as not to deal with difficult questions because he wanted to bask in what little glory there may have been in the receipt of Cadore's letter itself. ${ }^{54}$ (2) Had Armstrong insisted upon the prompt release of the despatch schooner allotted to him a month earlier, or had he made proper use of the Hornet, which had been sent especially to receive his despatches, and reached France about September 6, full knowledge of French pollcy would have reached Washington before deciolve stepe were taken by the President and Cabinet. In-tead, Armstrong left Paris on September 14, and spent nearly two months in French seaporte waiting for the release of his own transport, the Sally, which was caught up in a tax debate. 55 (3) Armetrong did not follow his instructions. Indeod, his entire course of action after August 5 was on par with this dereliction. Had he obeyed his July 5 , 
1810 instructions, he would have notified Cadore on the day they arrived, August 7, that France would have to agree to restore American property in order to bring about action against Great Britain. He could have obtained "either an agreement or an equally illuminating refusal." When he finally did raise the issue of confiscations, on September 7, he gave no hint that restoration was a sine qua non. Instead, he invited an unfavorable reply by asking whether it was the Emperor's will that selzures should be a subject of present or future negotiations between the two governments, or if the acts already taken by the Emperor were to be regarded as conclusive against remuneration. He had already infuriated Napoleon with a note castigating the misconduct of French privateers, just after the Emperor had heard that his advice boat, La Franchise, had been seized at New Orleans. (It was not known that the President had ordered the ship released.) Finally, Armstrong's last action before leaving for Bordeaux was to propose that American ships be restored to their owners on conditions that they put up bonds equal to the full value of the property--the bonds to be payable within $81 \times$ months if the Emperor made a decision to that effect. M. Petry presented the American case far more strongly to Cadore, and Cadore presented it far more strongly to the Emperor than Armstrong had to any of them. "His inaction and weak action, contrary both to the spirit and command of his instructions, removed the last barrier to the sweep on Bonaparte's rapacity." 56 By withholding the Trianon Decree from publication, Napoleon retained a free hand elther to keep on conflscating American vessels selzed before May 1, 1810, or to drop that policy without any visible inconsistency. Armstrong's delay forced the 
President to make his first and most important decision with a misleading indication of French policy before him. His decision was simple, though. If harm resulted from his action, it would be curable by Congress after February 2, 1811, when Non-Intercourse against Great Britain was to be renewed. 57

(4)Armstrong used the concession from Napoleon, even though an ambiguous one, as the occasion for leaving his diplomatic post in order to avoid a potentially embarrassing situation, living in fear that the Administration would disgrace itself and him by revealing his position as one of "mere gasconade." 58

In response to the first criticism of General Armstrong, an examination of the official correspondence does seem to reveal that he may not have communicated as much as might have been normally expected after having recelved a letter such as Cadore's. He did, as has already been demonstrated, Immediately notify the Secretary of State and the President of the existence of Cadore's letter of August 5, however, his failure to comment and assess the sincerity of Napoleon's intentions may have indicated, initially at least, that he believed he had finally achieved a diplomatic victory. No doubt Armstrong would have been delighted to have capped his diplomatic career with such a success. Although Madison must bear the greatest responsibility for issuing his proclamation on November 2, Armstrong must also accept some responsibility for possibly mieleading Madison initially. Quite possibly, however, Armstrong may have refrained from commenting more thoroughly about Cadore's letter, because of his desire to allow time to test the sincerity of the Emperor's actions before forming any concrete conclusions. 
Although Armstrong may not have offered as much analysis as he should have, he did, in fact, offer what he thought was a plausible explanation for the letter. In his despatch to the President of August 5, 1810, he had told the Prealdent that he attributed the Cadore letter to the fear of a possible war between the United States and France. 59 Although this may have been overrated as a reason, it was still an attempt at analysis of the circumstances which had produced the letter. To the charge that Armstrong did not further protest actual reprisals so as not to raise difficult questions, evidence to the contrary exists. In a letter to the Duke of Cadore of August 20, 1810, Armstrong informed him that a number of armed private vessels, flying the flag of France and acting under her authority, had violated the neutrality of the United States. Offensive and lawless as these acts were, they were more aggravating because of proof that they were not the isolated and occasional depredations of a few private adventurers, but the commencement of a system, origanized under the patronage of France. ${ }^{60}$ This would certainly seem to qualify as a protest. To discount criticism that Armstrong attempted to avoid difficult questions, one need only refer to Armstrong's note to Cadore of August 20, in which he asked for a full and explicit written declaration of the treatment that American comerce could expect to experience in the ports of France, both before and after November 1, and whether the seizures in Spain were to be regarded simply as sequestrations-and open, of course, to future negotiation--or as confiscations, and beyond the $11 \mathrm{mits}$ of compromise. 61 while he remained in Paris, Armstrong committed himself to press for an answer to this note. He 
reported, however, that there did not appear to be the slightest disposition to make reparation for past wrongs (as required in Smith's July 5 instructions), although the French officials were careful to employ terms which would not elfminate the hope that some reparation would be made. 62 Armstrong again inquired of Cadore on September 7 as to this issue, and to seek to know what would be the effect of the Emperor's decree of July, 1810, on American comerce, which had forbidden the departure of neutral ships from the ports of France, unless provided with imperial licenses. 63

Armstrong wrote to Secretary of State Smith on September 10, 1810, that he had not received anything worth communicating since his last despatch until Cadore's letter to him of September 7. By this letter it was learned that the Rambouillet Decree was not in operation and that American ships entering French ports before November 1 would be judged under the Berlin and Milan Decrees. Armstrong offered the opinion that the system of which those decrees were a part, was "...fast recovering the ground it had lost; \& I should not be astonished, were it soon to become as great a favorite as formerly." 64

Armstrong did not fail to ask difficult questions as he sought to determine the effect the revocation of the decrees would have on American commerce, were they actually revoked, nor did he fail to protest outrages that were brought to his attention. Although he may not have elaborated a great deal in his correspondence immediately after receipt of the Cadore letter, his letter of september 18, 1810, demonstrated that he was seriously questioning the actual revocation of the decrees, which implicitly reflected on his faith in the Emperor's promises. 
The second major criticism pertaining to the use of Armstrong's own transport ship, as opposed to others that he might have been able to employ, appears trivial. How was he to know that the Sally would be tied up in French red tape for as long as it was? In criticizing Armstrong on this point, one critic at least appears to be attempting to absolve Madison of his responsibility for the decisions that he made, by implying that if Armstrong had acted otherwise, information would have been received before Madison isoued his proclamation on November 2, 1810.65 The same critic appears to have overlooked the fact that Madison was inclined to action regardless of the information avallable to him. If he did not possess adequate information prior to issuing his decree, he did have the opportunity to delay his proclamation. Again, in February, 1811, the President had the advantage not only of further despatches from Europe, but also of a personal meeting with Armstrong on his return to the United States. Disregarding all available evidence that Napoleon had not actually revoked his decrees, Madison gambled again, for whatever reasons, and issued the proclamation of February 2, 1811. He alone must assume the responsibility for this action which ultimately brought the United States into the Continental System, and hence, involved her in war with Great Britain. The third major criticism, although partially valid, is much too severe. One must bear in mind that transportation difficulties rere a perennial problem during the early part of the 19 th century. With a war taking place at the ame time, diplomatic instructions, when finally received--if ever--were oftentimes outdated, or no longer appropriate for the representative abroad. The diplomat, therefore, needed to 
rely upon his own good judgment to determine what course to pursue-If any--ae a result of newly arrived instructions from his superiors. No one can know for sure why Armstrong did not notify Cadore on August 7 that France would have to agree to restore American property in order to bring about action against Great Britain, or why he waited until September 7 to raise the issue of confiscations. Quite possibly, Armstrong had determined to allow time to pass so as to ascertain Napoleon's sincerity as contained in the Cadore letter before launching into demands. Additionally, Armstrong 1s accused of weak action, contrary to the spirit of his instructions, when, in his last action before leaving Paris, Armstrong proposed that American ships be restored to their owners on condition that they put up bonds equal to the full value of the property. Ironically, this same critic chastised Armstrong for having infuriated Napoleon with a note castigating the mis-conduct of French privateers. ${ }^{66}$ On the one hand, Armstrong is criticized for being too $\mathrm{firm}$, and on the other, he 18 criticized for being too weak. Agreeing that Armstrong may not have followed his instructions precisely, is not to support the contention that he was derelict in his duty. Such a conclusion is biased and misleading. Finally, Armstrong has been accused of using the opportunity created by the Cadore letter to withdraw from France and from a potentially embarrassing position. Armstrong had determined, on various occasions, to return to the United States. When the Cadore letter was received on Auguat 5, he was in the process of preparing for his departure, a departure that had been approved by the Secretary of state and the President. 67 Armstrong had been placed in an embarrassing position 
almost from the very beginning of his mission. He, more than anyone else, was fully aware that his mission, at least until recelpt of the Cadore letter, had failed to achieve its objectives. The United States was merely a pawn that was caught up in the struggle between Great Britain and France, with her honor completely shattered. Armstrong had advocated force to shore up America's prestige, but his counsel was consistently ignored. Having been subjected to Napoleonic humiliation for six years, Armstrong was anxious to return to the United States. His departure shortly after the receipt of the Cadore letter was, most likely, colncidental. The decision to leave had been made a long time before.

Having examined the major criticisms of Armstrong's actions after August 5, 1810, a student of history, with the distinct advantage of knowing what actually happened, may engage in academic debates as to the probable outcome of events if only the leading characters of the time had acted differently. However, who can say for sure that the course of history might have been appreciably different if he had commented more or less about the incerity of the Cadore letter; that he should have taken a different ship home; that he should have followed this or that instruction more closely, or discarded this or that one; or that he should or should not have departed from France at the time he did? Granted, Armstrong's performance may not have been as exemplary during the last two months as it had been throughout most of his career, and he may even have been initially too hopeful that the decrees had been repealed, but neither was it as derelict as some would have students of history to believe, even though he was ending his 
mission and preparing to return to the United States. In the final analysis, this writer contends that Armstrong's actions, even if they had been any different than what they were, would probably have not greatly altered the course of events that ultimately transpired. 
Notes

Chapter $\mathrm{X}$

Melvin, 212.

2 Adans, v, 247.

${ }^{3}$ Melvin, 213.

4 See Armstrong to Madison, Aug. 5, 1810, Madison Papers LC, Reel

12. Perkins, 245, discounts this explanation.

5 Perkine, 245.

6 From Notes to the Minister of the Interior, June 25,1810 , as

cited in Adams, V, 244.

I Ibid., as quoted in Adars, V, 245.

${ }^{8}$ Armstrong to Smith, July 18, 1810, NA Despatches, Vol. XI;

Armstrong to Smith, July 10 (3), NA Despatches, Vol. XI, follows above letter. See ASPFR, III, 400, for the official, but incorrectly published text of the decree.

${ }^{9}$ Adams, V, 246-247.

${ }^{10}$ Armstrong to Smith, July 18, 1810, NA Despatches, Vol. XI.

IlMelvin, 206.

12 ASPFR, III, 400; Adams, 247-248.

${ }^{13}$ Adams, V, 248-249.

14 Ibid., 249.

15 Armstrong to Smith, July 10, 1810, NA Despatches, Vol. XI;

Adams, 251-252; Perkins, 245. On Aug. 7, Armstrong wrote to Smith and 
Informed him that he had received Smith's letter of July 5. A passage in it Indicated to Armstrong that a letter of an earlier date had been sent. If so, then it had been lost. Armstrong to Smith, Aug. 7, 1810, INA Despatches, Vol. XI.

16 Wapoleon to Cadore, July $31 ; 1810$, as quoted in Adams, v, 253. 17 Adams, v, 253.

${ }^{18}$ Cadore to Armstrong, Aug. 5, 1810, ASPFR, III, 386-387. ${ }^{19}$ Ibid.

20 Ibid.

21 Ibid.

22 Melvin, 213, states that the Trianon Tariff was a logical consequence of the navigation act of July, which Napoleon was anxious to implement.

23

3 Ibid., 216.

24 Ibid., 223.

${ }^{25}$ Gallatin to J.Q. Adams, Sept. 15, 1821, Writings of Gallatin,

II, 196-199; Adams, V, 258-259; Perkins, 247-248.

26 Gallatin to J.Q. Adams, Sept. 15, 1821, Writings of Gallatin, II, 197-199.

27 Armstrong to Smith, Aug. 5, 1810, INA Despatches, Vol. XI.

${ }^{28}$ Armstrong to Madison, Aug. 5, 1810, Madison Papers IC, Reel 12. Brant, Janes Madison, V, 210, states that iapoleon would have posed no problem to the world if he could have been scared that easily. Armstrong did not know that the plan to declare the Berlin and Milan Decrees repealed had been outlined by the Emperor on June 25, with Sept. I Instead of Nov. 1 as the effective date. Armstrong also did not know 
that Cadore's Aug. 5 letter had been drafted on July 25, two days before false war rumors reached Paris. Both facets of the new French policy--licenses and the revocation of the decrees--were Napoleon's response to the Macon Act, whose text had been published in the June 6, 1810 London Times. With trade set free by that act, the license system would prevent American ships from carrying British goods to French-held ports. By revoking his decrees, the Emperor could impose the French position and also promote greater Anglo-American strife.

${ }^{29}$ Armstrong to Madison, Aug. 5, 1010, Madison Papers LC, Reel 12. See also Arnstrorg to Smith, Aug. 7, 1810, NA Despatches, Vo1. XI. 30 Adans, V, 296; Smith to Pinkney, Oct. 19, 1810, NA Instructs., VII, 115-119.

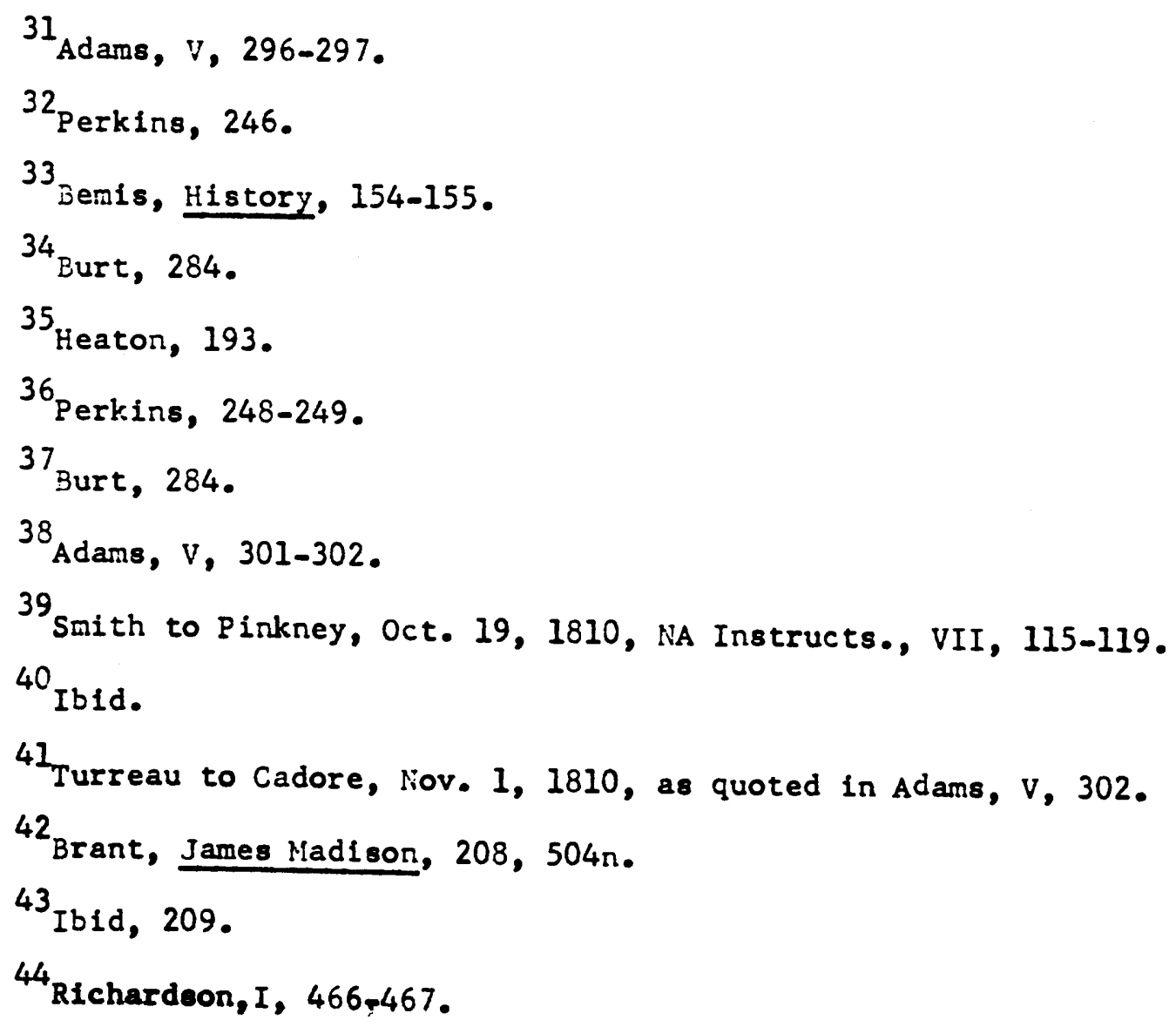


${ }^{45}$ Smith to Armstrong, Nov. 2, 1810, NA Instructs., VII, $122-124$. 46 Perkins, 250.

47 Ibid., 251; Madison to Jefferson, Oct. 19, 1810, Gaillard Hunt, ed., The Writings of James Madison, 9 vols. (New York, 1906), VIII, 109. ${ }^{48}$ Perkins, 251-252.

${ }^{49}$ Ibid., 252.

50 Ibid.

$5 I_{\text {Ibid. }}$

52 Melvin, 256.

${ }^{53}$ The harshest and most prominent critic of Armstrong'eperformance, especially his last months in France, is Brant, James Madison, v, 207-221. Brant, of course, has a distinct pro-Madison bias. Conversely, his anti-Armstrong bias, not only in the few chapters concerned with Armstrong's last months in France, but throughout the lengthy study on Madison, is also obvious. "James Madison and His Times," American Historical Review, L(1964), 652-571, is another of the author's extremely glowing works on Madison.

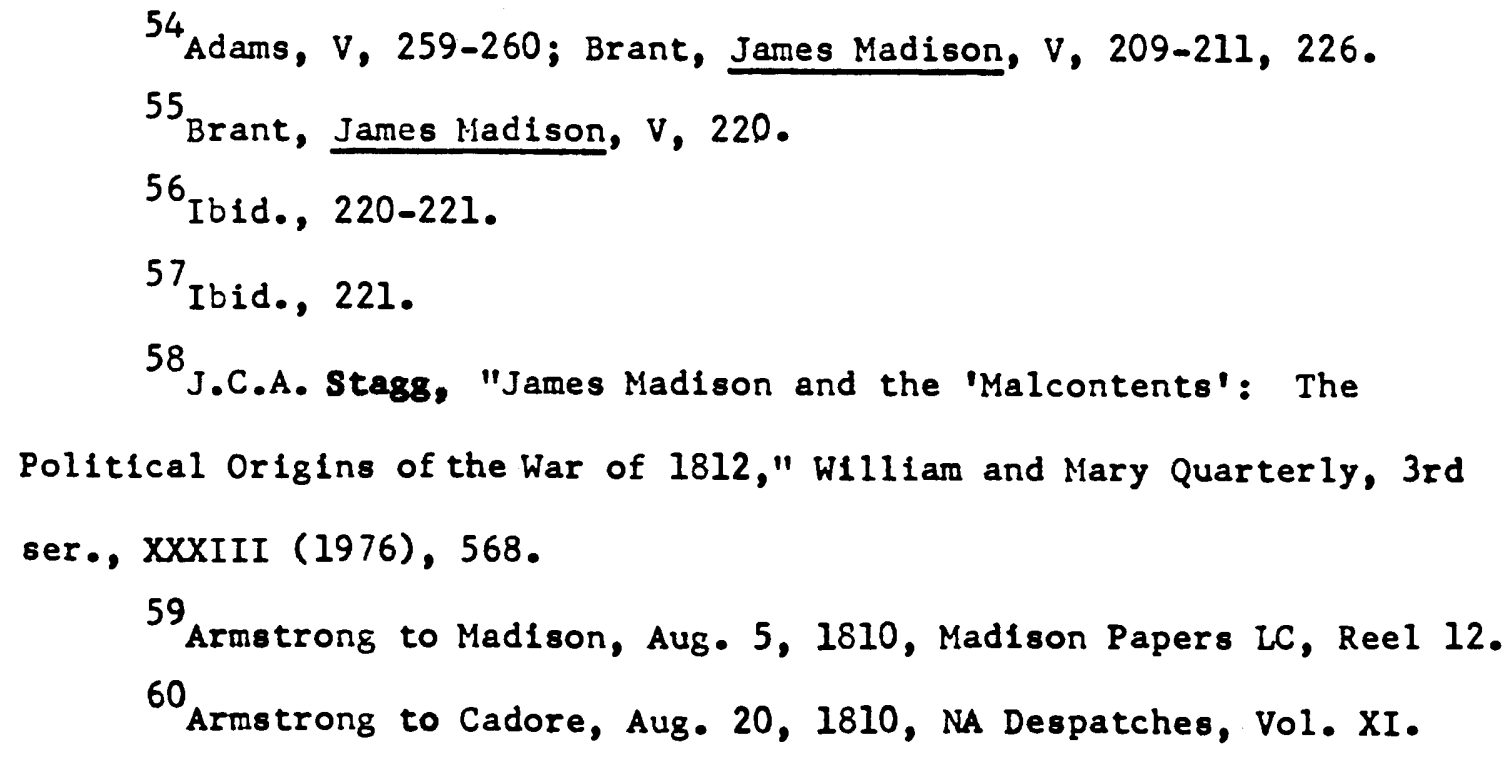


61 Ibid., Armstrong to Smith, Aug. 27, 1810, NA Despatches, Vo1. XI. 62 Armstrong to Smith, Aug. 27, 1810, iA Despatches, Vol. XI. ${ }^{63}$ Armstrong to Cadore, Sept. 8, 1310, NA Despatches, Vol. XI. ASPFR, III, 388, cites date of this letter as Sept. 7, 1810. See also Cadore to Armstrong, Sept. 12, 1810, ASPFR, III, 388-389.

64 Armstrong to Smith, Sept. 10, 1810, NA Despatches, Vol. XI.

65 Brant, James Madison, $v, 220$. ${ }^{66}$ Ijid., 220-221.

${ }^{67}$ Smith to Armstrong, May 22, 1810, NA Instructs., VII, 96-97. 


\section{CHAPTER XI}

END OF MISSION

On September 14, 1810, General Armstrong ended his mission in Paris and departed for Bordeaux, where he waited to board his ship for the return voyage to the United States. Armstrong left Jonathan Russell, a newly arrived legation secretary and a native of Rhode Island, in charge of the American legation. I Armstrong's last official despatch was addressed to Pinkney in London, and was dated September 29, 1810, in which Armstrong offered suggestions to Pinkney on how to deal with the British government in light of the Cadore letter. ${ }^{2}$ After contending with delay because of a tax squabble involving his transport ship for almost two months, ${ }^{3}$ Armstrong and his family departed from Bordeaux in November, ending his six-year career as United States Minister to France.

The thirty-day passage home was a good one until, while making land, Armstrong's ship struck a reef of rocks during a gail and was forced to lay at anchor without a rudder overnight. Miraculously, however, they made it into New London the next morning around the first of December. 4

Armstrong was feasted and honored by his fellow citizens in such cities as Baltimore, Philadelphia, and New York. There was talk of his running for Governor of Pennsylvania, Secretary of state, and even for President. 5 
In between feasts, Armstrong was preoccupied with tending to personal matters, which included settling his family in New York for the winter. These matters prevented him from traveling to Washington, D.C. immediately, and he expressed his apologies for this delay in a letter to the President, on December 11, $1810^{6}$ with these matters disposed of, Armstrong journeyed to Washington during the middle of the month, where he met with the President. ${ }^{7}$ One can speculate that Armstrong no doubt answered any questions as fully as he could regarding the Cadore letter, and the prospects for improved Franco-American relations.

Armstrong's return to the United States was not received without apprehension on the part of the Administration. There was fear that he might plan to run for important political office, such as Vice-President if he moved his residence to Pennsylvania. It is almost certain that he was approached by Republican "malcontents", most probably the Clintons. Initially, he appears to have expressed no interest in the election of 1812, although he was privately disgusted with Madison's policies. 8 Armstrong, however, was not inclined to be schismatic, even though he had the reputation of speaking his mind regardless of political expediencies. He believed as firmly as did Madison that anything which disrupted the Republican Party was not only unwise, but wrong. No doubt the Administration was relieved the General did not settle in Pennsylvania, but retired to his wife's estates in New York, happy to merely observe the increasing political and diplomatic problems of the Adminietration.9 As Minister to France, Armstrong had advocated the use of force to attain American objectives, and as a 
private citizen again, he saw that that was the best way of solving the country's 11ls, though he knew the Administration lacked the "spirit" to attempt $1 t^{10}$

The strained relations between Madison and the Smith brothers, in Robert Smith's removal as Secretary of State and subsequent public denunciation of the Administration, and the appointment of James Monroe as Smith's successor, sparked Armstrong's interest in the 1812 election, causing speculation that Armstrong, himself, might even head an antiMadison ticket. Armstrong was personally annoyed by the Cabinet change. He not only had severe doubts about Monroe's ablilty as a diplomat, but also feared that Monroe would be placed in a favorable position to succeed Madison to the Presidency. Armstrong complained to Judge Spencer of New York about the prospects with Monroe. He felt that this would do more to disrupt the Republican Party and the country than "anything that has yet occurred," and that the strength of the Union was no more than that of a mere "bundle of twigs." He further predicted that if Monroe attempted to succeed to the Presidency, the Republican Party's ascendency "must and will 80." In his opinion, neither the Western, Middle, not Northern states would "consent to take a third President in succession from Virginia." Armstrong hoped that Monroe and his Virginia supporters "would steer us clear of this rock" by turning down Madison's offer. 11 In this, Armstrong was to be disappointed.

When war finally broke out in 1812, DeWitt Clinton of New York, a Republican, determined to run for the Presidency against Madison, on an anti-war platform, appealing to "malcontent" Republicans and Federalists. 
He naturally expected Armstrong's support. However, Armstrong came out In eupport of Madison. On July 6, 1812, Armstrong accepted a cormission as a brigadier-general with the command of New York City and its defenses. ${ }^{12}$ Subsequent events and circumstances compelled Madison to nominate Armstrong for Secretary of War in January, 1813, and he held that position until the burning of Washington, D.C., which abruptly ended Armstrong's public career when he resigned on September 3, 1814.13

Although General Armstrong's public career may have come to an end, he was by no means silenced. He retired to Red Hook, New York, and devoted the majority of his time to agriculture and writing numerous works. His most important publication was Notices of the War of 1812 (1836), which was primarily a defense of his actions during the War of 1812. In this and other public works, as well as in some of his letters, he demonstrated the same caustic writing ability which had first distinguished him as the author of the "Newburgh Letters." He also contributed a "Life of Richard Montgomery" and a "Life of Anthony Wayne" to the Library of American Blography, ${ }^{14}$ and A Treatise on Agriculture (1839), a series of articles that he had written for the Albany Argus. ${ }^{15}$ On April 1, 1843, General John Armstrong, soldier, farmer, author, and statesman died in Red Hook, New York. He was laid to rest in Rhinebeck Cemetery, Rhinebeck, New York. 


\section{Notes}

Chapter XI

Melvin, 256; Russell to Smith, Sept. 26, 1810. Adams, v, 260, cites Sept. 12 as Armstrong's date of departure from Paris. 2 Armstrong to Pinkney, Sept. 29, 1810, ASPFR, III, 386. 3 Brant, James Madison, v, 220.

${ }^{4}$ Lee to Mrs. Susan Palfrey Lee, Dec. 12, 1810, Diary and Letters of Lee, 131-134.

5 Ibid., 134.

${ }^{6}$ Armstrong to Madison, Dec. 11, 1810, Madison Papers LC, Reel 12. 7 IbId.

${ }^{8}$ stagg, 568 .

9 Ib1d., 568-569.

${ }^{10}$ Ibid.; Armstrong to Ambrose Spencer, Feb. 11, 1811, as quoted in Stag8, 569.

11 Arnstrong to spencer, Mar. 19, 1811, as quoted in Stagg, 571572.

12 Dict. of Am. B10., I, 356; Alexander, I, 216.

${ }^{13}$ In the opinion of this writer, the definitive account of Armstrong's career as Secretary of War has still to be written. No small part of his difficulties stemmed from the intrigues of Monroe, as well as the need for a scapegoat for Madison

14 Jared Sparks, ed., L1brary of American Blography, 10 vols., 
lot ser., 1834-1838.

15 Dict. of Am. Bio., I, 358. 


\section{CHAPTER XII}

\section{CONCLUSION}

Having examined the diplomatic career of General John Armstrong as United States Minister to France, emphasizing the years 1806-1810, when the United States was increasingly subjected to the hostile effects of Napoleon's Continental System, what conclusions can logically be drawn from this study regarding Armstrong's effectiveness and performance?

First, the position of any American diplomat in France at this particular juncture in history would have been inherently difficult, if not impossible. liapoleon was a man with unrivaled ambition. In order to accomplish his objectives, he did not shrink from employing not only force, but whatever other means were within his power, to obtain the desired results. He was, foremost, a man of expediency. He had absoIutely no qualms about breaking promises, deceiving, or outright lying Standard diplomatic interaction with such a man must necessarily have been a risky and exasperating experlence. To Armstrong's credit, he discerned Napoleon's personal characteristics and tendencies very early in his career. Therefore, he had few illusions about the difficulties and dangers in dealing with the Emperor or with his ministers. Armstrong was, in most respects, a realist, in contrast to the majority of American leadership as represented by Jefferson and Madison, who doggedly persisted in the bellef for far too long that Napoleon, despite his 
ambition, was still a reasonable man who could loglcally be counted on to act according to his best interests as they perceived them to be.

Compounding the difficulty of Armstrong's position was the miserably weak military and naval posture of the United States, and American leadership's hesitancy to bolster it, as well as their continucd reluctance to employ avallable force whenever more peaceable diplomatic means had failed to obtain their objectives. Jefferson and Madison clung to faith in the principle of peaceable econonic coercion, long after any reasonable hope for success existed. Recognizing that standard diplomatic means were not going to achieve diplomatic objectives, Armstrong recommended more forceful measures on numerous occasions to acquire desired territorial objectives, resist increasing violation of American neutral rights by both France and Great Britain, or support such Intangible interests as national honor. Although flexing American muscle would have entailed relatively little risk on several occesions, with almost certain success, the Administration consistently rejected Armstrong's advice and shied away from conflict. Armstrons was, therefore, left to defend the American position by any other means he could, while functioning in a world governed by force.

As Vapoleon intensified his Continental System, violating not only established international law, but also an existing Franco-American treaty, Armstrong's temper and accompanying official protests increased proportionately. He firmly and persistently sought the repeal of the Napoleonic decrees that adversely affected American commerce, and was constantly alert to possible new measures. He did not merely accept the superficial pretexts oftentimes offered by French officials 
88 the rationale for their actions, but earnestly sought to penetrate the diplomatic gloss to discern their true motives and intentions. Superb in debate and analysis, Armstrong possessed the ablitty to quickly discern errors, misstatements, and obvious fallacies of argument in the countless oral and written correspondences he received from representatives of the French government. Almost unequalled with a pen, his notes, when angry, were laced with the caustic tone which had long distinguished him. The Emperor himself was not immune when Armstrong felt he was deserving of harsh remonstrance, which was most of the time.

From the year 1808 on, Armstrong was increasingly frustrated and pessimistic about his mission. He recognized the futility of maintaining an American minister in France in light of the compounding circumstances. Despatches increasingly reflected his desire to return to the United States, although he postponed his departure on several occasions in order to remain and pursue other avenues which might have held a slight possibility of Improving the American position. On numerous occasions, he demonstrated his willingness to take the initiative in diplomatic gambles. Two examples already discussed, but characteristic of this trait, were his efforts to enlist the support of Russian Foreign Minister Romanzoff, and his visit to Holland to encourage the Emperor's own brother to aid American commercial interests. In both of these instances, as well as in others, Armstrong's knowledge and understanding of events and personalities were obvious. Indeed, his information was unusually good. Armstrong sought most any means as a potential source of information that might ald his position--certainly 
the mark of a good diplomat, though his own colleagues occasionally frowned on the character of some of his sources. ${ }^{l}$

Despite Armstrong's diligent efforts to force Napoleon to respect American neutral rights, and angered by the Emperor's repeated demonstrations of bad faith, Armstrong, after having exhausted all the normal means of diplomatic protest, pursued other means more unconventional that were quite bold. In his continual protest of Napoleonic abuses, one such mears was Armstrong's ploy of absenting himself from Court. This was one way for Armstrong to express his extreme displeasure over Napoleon's brutal enforcement of the Continental system. This form of protest was vicwed by most as an effrontery to the Emperor, and not likely to enhance Armstrong's popularity with French officialdom. This move, combined with Armstrong's bold and forceful notes of protest, was a gesture which Napoleon could hardly fathom from the representative of a mere repuilic. ${ }^{2}$ Consequently, by 1810, the Emperor's tolerance reached its limit, and he requested Armstrong's recall. Ordinarily, this would be a negative reflection on the minister being recalled, but given the circunstances and personalities involved, it must be viewed as a complinent to General Armstrong. Here, at least, was one representative of a foreign government who was not easily intimidated by Napoleon's awesome power, and one who did not succumb to the Emperor's every whim. In standing up to Napoleon as he did, Armstrong succeeded in ruffling the feathers of His Imperial Majesty--something to which Napoleon was not accustomed. While the United States may have been almost militarily inconsequential and its leadership unrealistic and vacillating, at least one individual stood up for her honor. 
In the final analysis, however, Armstrong's mission must be judged a fallure, insofar as he did not accomplish his diplomatic objectives in Paris, or in convincing American leadership to accept his advice and employ force on several occasions. Armstrong was unsuccessful in forcing the Emperor to respect American neutrality by repealing his offensive decrees. ${ }^{3}$ Even the Cadore letter, which at flrst seemed to be the croming achievement of Armetrong's diplomatic career, soon proved to be nothing more than deception so characterietic of Napoleon. 4

Although Armstrong may not have been successful in accomplishing his objectives, he had at least accomplished as much as anyone could have, given the circumstances of the times, and the character of Napoleon. Indeed, the United States of the early 19 th century would have had great difficulty finding another person who could have done better. There were certainly many who would not have done as well. Armstrong's successors in Paris, Russell and Barlow, for exanple, though both competent and able men, experienced the same frustrations and failures as had Armstrong. 5 Armstrong's shear ability and stamina to persist in a European diplomatic post for six years during one of the most difficult periods in American history is a credible feat in itself. General Armetrong'• years as minister to France represented a tremendous personal sacrifice on his part in the service of his country. He could have remained in the United States, guaranteed a prominent place in American politics, or returned from his post when he first recognized the unlikely prospect for success or glory. Instead, he stayed for six long years.

In spite of the publicity and debate that surrounded his subse- 
quent tenure as Secretary of War, the United States owes him a great deal of gratitude and appreciation. As Armstrong returned to the United States, ending his diplomatic career, Jefferson expressed best the debt which the American people owed Armstrong for the years of service he had devoted to his country. Jefferson wrote to Armstrong: "I an very happy to see that our fellow citizens are disposed to receive you with the welcome, and expressions of thankfulness which your exertions for their good have merited." 6 
Notes

Chapter XII

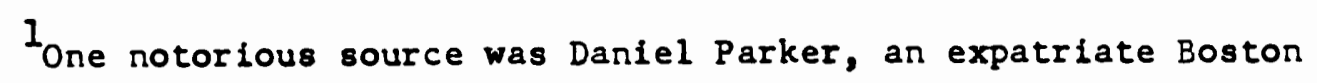
speculator. During the negotiatiors for West Florida, Parker had served as Talleyrand's emissary in offering the Floridas for $\$ 10,000,000$. James Bowdoin, who was assigned as a joint commissioner along with Armstrong to settle Spanish-American differences, wrote that Armstrong was "daily closeted with him [Parker], \& who by means of intrigue has converted himself into a kind of minister of the U.S.l" Janes Bowdoin to George Erving, Sept. 9, 1806, Bowdoin and Temple Papers, VI, 326. 2 Another illustration of Ilapoleon's attitude toward the United States may be seen in the incident in which Napoleon complained to Champagny that he had "received letters from Mr. Madison, new President of the United States, having the address 'to our great and good friend,' etc." He wished to know if it was correct protocol for the head of a mere republic to use terms which might be expected from fellow monarchs. Champagny, note on protocol, May 9, 1809, as quoted in Brant, James Madison, V, 80, states: "Napoleon's complaint was significant: it meant that he was able to think of the United states only as a vassal or an enemy, not as an ally or a neutral with valid rights." 
3urt, 281, statee: "General Armstrong was always protesting; but he might as well have prayed to Neptune for the restoration of ships from the bottom of the sea."

${ }^{4}$ The correspondence of Jonathan Russell and Joel Barlow clearly illustrates Napoleon's intent to delay and to decelve. Seizure of American ehips continued under the Berlin and Milan Decrees. Napoleon had no intention of revoking his decrees, especially when he regarded them as the "fundamental laws" of his empire. Russell to Smith, April 4, 1811, NA Despatches, Vo1. 12. Only when Napoleon was confronted with the prospects of war with Russia, plus the formal declaration of the Prince Regent of April 21, 1812 forcing Napoleon's hand to produce evidence of the repeal of his decree, did the Emperor cause to be produced a decree signed by him at St. Cloud April 28, 1811, declaring his previous decree non-existent for American vessels after Nov. 1, 1810. This document greatly surprised Barlow, who inquired from the Duke of Bassano, Cadore's replacement, if it had been promulgated. Bassano told Barlow it had not, but stated that it had been communicated at the time to Russell and sent to Serurier, French minister to the United States, with orders to communicate it to the Secretary of state. This was an outright falsehood. The docunent was predated to fulfill an expedient need of Napoleon's. See Barlow to Bassano, May 1, 1812, ASPFR, III, 602; Barlow to Monroe, May 12, 1812, ASPFR, III, 603; Adams, VI, 255-256. For a good account of French delay and deception in revoking the decrees, see Adams, V, 380-403; VI, 245-266. 5 Even after word arrived in France on Aug. 8, 1812, that the United states had declared war against Great Britain, there was no 
practical indication of change in the Imperial policy toward the United States. The Berlin and Milan Decrees were no more repealed by the St. Cloud Decree, than they had been by Cadore's letter of Aug. 5, 1810. While Bassano protested to Barlow against implications of the Emperor's good faith, Bassano's colleagues equally protested to Barlow that they had no authority to exempt American ships from the operation of the decrees. Decrès, the Minister of Marine, gave orders to his cruisers to destroy all vessels violating the decrees. This delay and duplicity, almost simultaneous with Napoleon's defeat in Poland, caused Barlow to attempt one last settlement which ultimately cost him his 1ife. On Oct. 26, he set out for Wilna at the request of Bassano, only to arrive on Nov. 18 to find the place in disarray as a result of Napoleon's retreat from Moscow. On his return to Paris, Barlow, having travelled day and night in $-13^{\circ} \mathrm{F}$. weather, died of pneumonia and fatigue near Crackow. Adams, VI, 255-61. See also Bassano to Dalberg, Aug. 10, 1812, as quoted in Adams, VI, 260-261. 6 Jefferson to Armstrong, DeC. 13, 1810, Jefferson Papers LC, Reel 44. 
Sources Consulted

Bibliographical Guides

Bemis, Samuel Flagg, and Grace Gardner Griffin. Gulde to the Diplomatic History of the United States, 1775-1921. Washington, D.C., 1935.

Goodman, Warren H. "The Origins of the War of 1812: A Survey of Changing Interpretations." Mississippl Valley H1storical Review, XXVIII (1941-1942), 171-176.

Ferguson, James E., ed. Confederation, Constitution, and Early National Period, 1781-1815. Northbrook, I1., 1975.

Freidel, Frank, ed. Harvard Guide to American History. rev. ed. 2 vols. Cambridge, Mase., 1974.

Morison, Samuel Eliot, et al., eds. Harvard Guide to American History1954 ; rpt. Cambridge, Mass., 1963.

National Archives. Compreheneive Guide to the National Archives. Washington, D.C., 1972.

Paullin, Charles, and Frederic Paxson, eds. Guide to the Materials in London Archives for the History of the United States SInce 1783. Washington, D.C., 1914.

Manuscript Sources

National Archives, Washington, D.C.:

U.S. Department of State Records. Despatches from United States Ministers to France. Vols. IX-XII. Microfilm copy.

U.S. Department of State Records. Diplomatic Instructions: All Countries. Vole. VI-VII. Microfilm copy.

Maseachusetts Historical Soclety, Boston:

Timothy Pickering Papers. Microfilm copy.

Libraxy of Congress, Washington, D.C.

Thomas Jefferson Papers. Microfilm copy.

James Madison Papers. Microfilm copy. 
James Monroe Papers. Microfilm copy•

New York Public Library, New York:

Samuel Ward Papers. Microfilm copy.

University of Virginia, Charlottesville:

Cabell Gwathmey Collection of Autographs and Letters. Micro-

film copy.

Public Documents: Printed

Annals of Congress: Debates and Proceedings in the Congress of the United States. 42 vols. Washington, D.C., 1834-1856.

Claussen, Martin P., ed. The Congressional Journals of the United States. 65 vols. The National State Papers of the United States Series, 1789-1817, Part I. Wilmington, Del., 1977.

Cobbett's (Hansard) Parliamentary Debates. London, 1803-1812. Vols. I-XXIII. Microcard copy.

Cruikshank, Ernest A., ed. Documents Relating to the Invasion of Canada and the Surrender of Detroit, 1812. Ottowa, 1912.

Israel, Fred L., ed. The State of the Union Messages of the Presidents, 1790-1966. 3 vols. New York, 1966. Vol. I.

Lowrie, Walter, and Matthew St. Clair Clark, eds. American State Papers, Foreign Relations. 6 vols. Washington, D.C., 1832-1859. Microcard copy.

Mayo, Bernard, ed. Instructions to the British Ministers to the United States 1791-1812. American Historical Association, Annual Report, 1936. 3 vols. Washington, D.C., 1941.

Miller, Hunter, ed. Treaties and Other International Acts of the United States of America, 1776-1863. 8 vols. Washington, D.C., 19311948. Vol. II.

Richardson, James D., ed. A Compilation of the Messages and Papers of the Presidents, 1789-1897. 20 vols. Washington, D.C., 18971917. Vols. I and II.

State Papers and Publick Documents of the United States, from the Acceseion of George Washington to the Presidency, Exhlbiting a Complete View of Our Foreign Relations since That Time. 3rd ed. II vols. Boston, 1819. 
Contemporary Writinge

Adams, Charles Francis, ed. Memoirs of John Quincy Adams Comprising Portions of His Diary from 1795 to 1848. 12 vols. 1874-1877; rpt. Freeport, N.Y., 1969.

Adams, Henry, ed. The Writings of Albert Gallatin. 3 vols. 1879; rpt. New York, 1960 .

Ames, Seth, ed. Works of Fisher Ames with a Selection from His Speeches and Correspondence. 2 vols. Boston, 1854.

Armstrong, John. Notices of the War of 1812. 2 vols. New York, 18361840.

Bigelow, Abijah. "Letters of Abijah Bigelow, Member of Congress, to His Wife, 1810-1815." American Antiquarian Society Proceedings, New ser., XI (1930), 305-406.

Bowdoin, James. The Bowdoin and Temple Papers. Part II. Massachusetts Historical Society Collections. 7th ser. Boston, 1930. Vol. VI.

Bourrienne, Louis Antoine Fauvelet de. Memoirs of Napoleon Bonaparte. 4 vols. R.W. Phipps, ed. New York, 1810.

Boyd, Julian P., et al., eds. The Papers of Thomas Jefferson. 19 vols. to date. Princeton, 1950- -

Brown, Dorothy, ed. "Excerpts from Two PInkney Letter Books." Maryland Historical Magazine, LV, No. 4 (1960), 360-370.

Brown, Everett Somerville, ed. William Plumer's Memorandum of Proceedinge in the United States Senate, 1803-1807. New York, 1923.

Brown, Stuart Gerry, ed. The Autobiography of Jamee Monroe. Syracuse, N.Y., 1959.

Clark, Allen C., ed. Life and Letters of Dolly Madison. Washington, D.C., 1914.

Cutler, William Parker and Julla Perkins Cutler, ed. Life, Journals and Correspondence of Rev. Manasseh Cutler. 2 vols. Cincinnati, Oh., 1888.

Donnan, Ellzabeth, ed. The Papers of James A. Bayard, 1796-1815. American Historical Association Annual Report, 1913. 2 vols. Washington, D.C., 1915. Vol. II. 
Fitzpatrick, John C., ed. Writings of George Washington. 39 vols. Washington, D.C., $1931-1944$.

Ford, Paul Leicester, ed. The Writings of Thomas Jefferson. 10 vols. New York, 1892-1899.

Ford, Worthington C., ed. "Letters of William Duane." Massachusette Historical Society, Proceeding8, 2nd ser., XX (1906-1907), 257394.

Garambouville, Louis M. Turreau de. Apercu sur la Situation Politique des États-Unis D'Amérique. Paris, 1815.

Hamilton, Stanislaus Murray, ed. The Writings of James Monroe. 7 vols. New York, 1898-1903.

Haynes, George Henry. "Letters of Samuel Taggart, Representative in Congres8, 1803-1814." American Antiquarian Society Proceedings, New ser., XXXIII (1923), 113-226.

Hopkins, James F. et al., eds. The Papers of Henry Clay- 10 vols. to date. Lexington, $\mathrm{Ky} \bullet, 1959-$. Vol. I.

Hunt, Gaillard, ed. The Writings of James Madison. 9 vols. New York, 1906.

King, Charles R., ed. The Life and Correspondence of Rufus King.

6 vols. 1894-1900; rpt. New York, 1971.

Lecestre, Leon, ed. Lettres Inédites de Napoléon Ier (An VIII-1815). 2nd ed. 2 vols. Paris, 1897.

Lipscomb, Andrew A., and Albert Ellery Bergh, eds. The Writings of Thomas Jefferson. 20 vols. Washington, D.C., 1903-1904.

Malone, Dumas, ed. Correspondence Between Thomas Jefferson and Plerre Samuel du Pont de Nemours, 1798-1817. Boston, 1930.

Mann, Mary Lee, ed. A Yankee Jeffersonian, Selections from the Diary and Letters of William Lee of Massachusetts Written from 1796 to 1840. Cambridge, Ma8s, 1958.

Mays, Davld J., ed. Letters and Papers of Edward Pendleton. 2 vols. Charlottesville, Va., 1967.

MCGrane, Reginald C., ed. The Correspondence of Nicholas Biddle Deallng with National Affairs: 1807-1844. Boston, 1919.

Meriwether, Robert L. et al., eds. The Papers of John C. Calhoun. 12 vols. to date. Columbia, S.C., 1959-. Vol. I. 
Mullet, Charles F., ed. "British Schemes Against Spanish America in 1806," Hispanic American Historical Review, XXVII (1947), 269278.

Nevins, Allen, ed. The Diary of John Quincy Adams, 1794-1845: Amer1can Diplomacy, and Polltical, Soclal, and Intellectual Life, from Washington to Polk. 1951; rpt. New York, 1969.

Robertson, James Alexander, ed. Loulsiana Under the Rule of Spain, France, and the United States, 1785-1807: Social, Economic and Political Conditions of the Territory Represented in the Loulsiana Purchase. 2 vols. Cleveland, 1911.

Smith, John Cotton. The Correspondence and Miscellanies of the Hon. John Cotton Smith, Ll.D. New York, 1847.

Steiner, Bernard C., ed. "Some Papers of Robert Smith, Secretary of the Navy 1801-1809 and of State 1809-1811" Maryland H1stor1cal Magazine, XV (1925), 139-150.

Taylor, John. "John Taylor Correspondence." John P. Branch Historical Papers of Randolph-Macon College. II, No8. 3\&4 (I908), 4-6.

Waystaff, H.M., ed. The Papers of John Steel. 2 volo. Raleigh, N.C., 1924.

Wheaton, Henry, ed. Some Account of the Life Writings, and Speeches of William Pinkney. New York, 1826.

Worthington, R., ed. Letters and Other Writings of James Madison, Fourth President of the United States. 4 vols. New York, 1884.

Contemporary Newspapers and Magazines

National Intelligencer. Washington, D.C., 1803-1815.

Netional Reg18ter. London, 1803-1811. Vols. XLV-IIII.

Books

Adams, Henry. A History of the United States of America During the Administrations of Thomss Jefferson and James Madison. 9 vols. New York, 1889-1891.

The Life of Albert Gallatin. 1879; rpt. New York, 1943. Ager, Herbert, ed. The Formative Years. 2 vols. New York, 1947. 
Alexander, De Alva Stanwood. A Pol1tical H1story of the state of New York. 3 vols. New York, 1906.

Ammon, Harry. James Monroe: The Quest for National Unity- New York, 1971.

Andrews, Edward I. Napoleon and America: An Outline of the Relations of the United States to the Career and Downfall of Napoleon Bonaparte. New York, 1909.

Bailey, Thomas A. A Diplomatic History of the American People. 8th ed. New York, 1969.

Bassett, John Spencer. The Life of Andrew Jackson. New York, 1916.

Beirne, Francis F. The War of 1812. Handen, Conn., 1965.

Bemis, Samuel Flags, ed. The American Secretaries of State and Their Diplomacy. Vol. III. 1928; rpt. New York, 1963.

- A Diplomatic History of the United States. 5th ed. New York, 1965.

B1rd, Harrison. War for the West, 1790-1813. New York, 1971.

Blumenthal, Henry. France and the United States: Their Diplomatic Relations, 1789-1914. Chapel Hill, N.C., 1970.

Bonnel, Ulane. La France Les États-Unis et la Guerre de Course (17971815). Paris, 1961.

Bowers, Claude G. Jefferson in Power: The Death Struggle of the Federalists. Boston, 1936.

Bowman, Albert Hall. The Struggle for Neutrality: Franco-American Diplomacy During the Federal1st Era. Knoxville, 1974.

Brant, Irving. James Madison. 6 vols. Indianapolis, 1948-1961.

Brigg8, Herbert W. Doctrine of Continuous Voyage. Baltimore, 1926.

Brodie, Fawn M. Thomas Jefferson: An Intimate History- New York, 1974.

Brown, Roger H. The Republ1c in Per11: 1812. New York, 1964.

Bruce, William Cabell. John Randolph of Roanoke, 1773-1833. 2nd ed. rev. New York, 1939.

Burt, A.L. The United States, Great Britain and North America: From The Revolution to the Establishment of Peace After the War of 
1812. New York, 1961.

Castelot, André. Histoire de Napoléon Bonaparte. 10 vols. Paris, 1969.

Chinard, Gilbert. Thomas Jefferson, the Apostle of Americans. 2nd ed. Ann Arbor, 1960 .

Clauder, Anna C. American Commerce as Affected by the Wars of the Erench Revolution, 1793-1812. 1932; rpt. C11fton, N.J., 1972.

Coles, Harry 1. The War of 1812. Chicago, 1965.

Connelly, Owen. French Revolution: Napoleonic Era. New York, 1979.

Cox, Isaac Joslin. The Weat Florida Controversy, 1798-1813: A Study In American Diplomecy. Baltimore, 1918.

Darling, Arthur. Our Rising Empire, 1763-1803. New Haven, 1940.

Dangerfield, George. Chancellor Robert R. Livingston, 1746-1813. New York, 1960.

- The Era of Good Feellngs. New York, 1952.

DeConde, Alexander. Entangling Alliance: Polltics and Dlplomacy Under George Washington. Durham, N.C., 1955.

1971.

A History of American Foreign Policy. 2nd ed. New York,

- The Quas1-War: The Politics and Diplomacy of the Undec lared War With France, 1797-1801. New York, 1966.

-.-.-.-. This Affair of Loulelana. New York, 1976.

Ferre11, Robert H. American Diplomacy. 2nd ed. New York, 1969.

Gilman, Daniel C. Jamee Madison in Hie Relations to the Public Service During Half a Century. American Statesmen Series. Boston, 1883.

Gilpin, Alec R. The War of 1812 in the Old Northwest. East Lansing, 1958.

Heckscher, Ell F. The Continental System: An Economic Interpretation. Oxford, 1922.

Hiteman, J. Mackay. The Incredible War of 1812: A Military HistoryToronto, 1965.

Hor sman, Reginald. The War of 1812. New York, 1969. 
Jenning,, Walter Wilson. The Amerlcan Embargo, 1807-1809. Univ. of Iowa Studies in the Social Sciences, No. 55. Iowa City, 1921.

Johnson, Allen, and Dumas Malone, ede. Dictlonary of American Blography. 22 vols. New York, 1946.

John, Allen. Jefferson and His Colleagues: A Chronicle of the Virginia Dynasty. The Chronicles of America Series, Vol. 15. New Haven, 1921.

Kaplan, Lawrence S. Jefferson and France: An Essay on Politics and Political Ideas. New Haven, 1967.

Lefebvre, Georges. Napoleon. 5th ed. 2 vols. Trans. Into Eng. by Henry Stockhold. New York, 1969.

Lloyd, Alan. The Scorching of Washington: The War of 1812. Washington, D.C., 1974.

Lucas, C.P. The Canadian War of 1812. Oxford, 1906.

Mahan, A.T. The Influence of Sea Power Upon the French Revolution and Empire, 1793-1812. 2 vols. London, 1892.

Sea Power in Its Relations to the War of 1812. 2 vols. London, 1903.

Malone, Dumas. Jefferson and His Time. 5 vols. New York, 1948-1974.

Marsha11, Thomas M. A History of the Western Boundary of the Louisiana Purchase, 1819-1841. New York, 1970.

McAfee, Robert B. History of the Late War in the Western Country. Lexington, $\mathrm{Ky} \cdot, 18 \mathrm{Ib}$.

McDonald, Forrest. The Presidency of Thomas Jefferson. Lawrence, Kan. 1976.

Melvin, Frank Edgar. Napoleon's Navigation System. New York, 1919.

Perkins, Bradford. Castlereagh and Adams: England and The United States, 1812-1813. Berkeley, 1964.

-... The First Rapprochement: England and the United States, 1795-1805. Philadelphia, 1955.

--- Prologue to War: England and the United States, 18051812. Berkeley, 1961.

Peterson, Merr111 D., ed. James Madison, A Blography in H1s Own Words. New York, 1974. 
-...-.-.-. Thomas Jefferson and the New Nation: A Blography. New Haven, 1967.

Pratt, Fletcher. The Heroic Years: Fourteen Years of the Republic, 1801-1815. New York, 1934 .

Pratt, Julius W. Expansionists of 1812. Gloucester, Mas8., 1957.

Richardson, Hubert N.B. A Dictionary of Napoleon and His Times. New York, n.d.

Robert8on, William Spence. Francisco de Miranda and the Revolutionizing of Spanish America. American Historical Association Annual Report, 1907. Washington, D.C., 1908. Vol. I.

Schachner, Nathan. Thomas Jefferson: A Blography. 5th ed. New York, 1967.

Sears, Louls Martin. Jefferson and the Embargo. Durham, N.C., 1927.

Shulim, Joseph I. The Old Dominion and Napoleon Bonaparte: A Study in American Opinion. New York, 1952.

Smelser, Marshall. The Democratic Republic, 1801-1805. New York, 1968.

Smith, James Morton. Freedom's Fetters: The Alien and Sedition Laws and American Civil Liberties. Ithaca, N.Y., 1956.

Tans111, Charles Callan. The United States and Santo Domingo, 17981873: A Chapter in Car1bbean Diplomacy- 1938; rpt. Gloucester, Mas8., 1967.

Thiers, M.A. Histoire du Consulat et de L'Empire. 10 vols. Paris, $1845-1862$.

Updyke, Frank A. The Diplomacy of the War of 1812. 1915; rpt. Gloucester, Mass., 1965 .

Varg, Paul A. Foreign Policies of the Founding Fathers. East Lansing, Mich., 1963.

Walsh, Robert. An Inquiry Into the Past and Present Relations of France and the United States. London, 1811.

Walters, Jr., Raymond. Albert Gallatin: Jeffersonian Financier and Diplomat. New York, $195 \%$.

-..--.-.-. The Virginia Dynasty: The United States, 1801-1829. New York, 1965 .

Wandell, Samuel H. and Meade Minnigerode. Aaron Burr. 2 vols. New 
York, 1943.

Whitaker, Arthur. The Mississippi Question, 1783-1803. New York, 1934.

White, Leonard. The Jeffersonian--A Study in Administrative History. 1801-1829. New York, 1951.

White, Patrick C.T. A Nation on Trial: America and the War of 1812. New York, 1965.

Willson, Beckles. America's Ambassadors to France, 1777-1927: A Narrative of Franco-American Relations. London, 1928.

Wilson, Lyon E. Louisiana in French D1plomacy, 1759-1804. Norman, Ok., 1934.

Zimmerman, James Fulton. Impressment of American Seamen. 1925; rpt. New York, 1966.

Articles

Adams, Mary P. "Jefferson's Reaction to the Treaty of San Ildefonso." Journal of Southern History, XXI (1955), 173-188.

Brant, Irving. "Joel Barlow, Madison's Stubborn Minister." William and Mary Quarterly, 3rd ser., XV (1958), 438-451.

-..-.-.-.. "James Madison and His Times." American Historical Review, LVI (1951-1952), 853-870.

Coatsworth, John H. "American Trade with European Colonies in the Caribbean and South America 1790-1812." William and Mary Quarter1y, 3rd ser., XXIV (1967), 243-266.

Cox, Isaac J. "The Pan-American Policy of Jefferson and Wilkinson." Mississippi Valley H1storical Review, I (1914-1915), 212-239.

Egan, Clifford L. "The United States, France, and West Flor1da." Florida Historical Quarterly, XIVII, No. 1 (1968), 227-252.

Gloves, Richard. "The French Fleet, 1807-1814: Britain's Problem and Madison's Opportunity." Journal of Modern History, XXXIX (1967), 233-252.

Heaton, Herbert. "Non-Importation, 1806-1812." Journal of Economic History, I (1941), 178-198.

Kaplan, Lawrence S. "France and Madison's Decision for War, 1812." Mississippi Valley Historical Review, I (1964), 652-671. 
- "Jefferson's Foreign Policy and Napoleon's Idéologues." WIIIIam and Mary Quarterly, 3rd ser., XVIII (1962), $344-359$.

-...-.-.-. "Jefferson, the Napoleonic Wars, and the Balance of Power." William and Mary Quarterly. 3rd ser., XIV (1957), 196-217.

Kohn, Richard H. "The Inside History of the Newburgh Conspiracy: America and the Coup d'État." William and Mary Quarterly, 3rd ser., XXVII (1970), 187-213.

Nelson, Paul David. "Horatio Gates at Newburgh, 1783: A Misunderstood Rule." William and Mary Quarterly, 3rd ser., XXIX (1922), 143158.

Perkins, Bradford. "Sir William Scott and the Essex." William and Mary Quarter1y, 3rd ser., XIII (1956), 169-183.

Peterson, Merrill D. "Thomas Jefferson and Commercial Policy." William and Mary Quarterly, 3rd ser., XXII (1965), 584-61l.

Robertson, William Spence. "Francisco de Miranda and the Revolution1zing of Spanish America." American Historical Association, Annual Report, 1907.

Skeen, Edward C. with a rebuttal by Richard H. Kohn. "The Newburgh Conspiracy Recons1dered." William and Mary Quarterly, 3rd ser., XXXI (1974), 272-298.

Stag8, J.C.A. "James Madison and the 'Malcontents's The Political Origirs of the War of 1812." William and Mary Quarter1y, XXXIII (1976), 557-585.

Steiner, Bernard. "Instructions and Note of Robert Smith, 1810, 1811." American Historical Review, XXX (1924-1925), 553-556.

Stockder, Archibald N. "The Legality of the Blockade Instituted by Napoleon's Decree, and the British Orders in Council, 18061813." American Journal of International Law, X (1916), 492503. 